Prepared in cooperation with the U.S. Army Corps of Engineers and the Oregon Association of Clean Water Agencies

\title{
Thermal Effects of Dams in the Willamette River Basin, Oregon
}

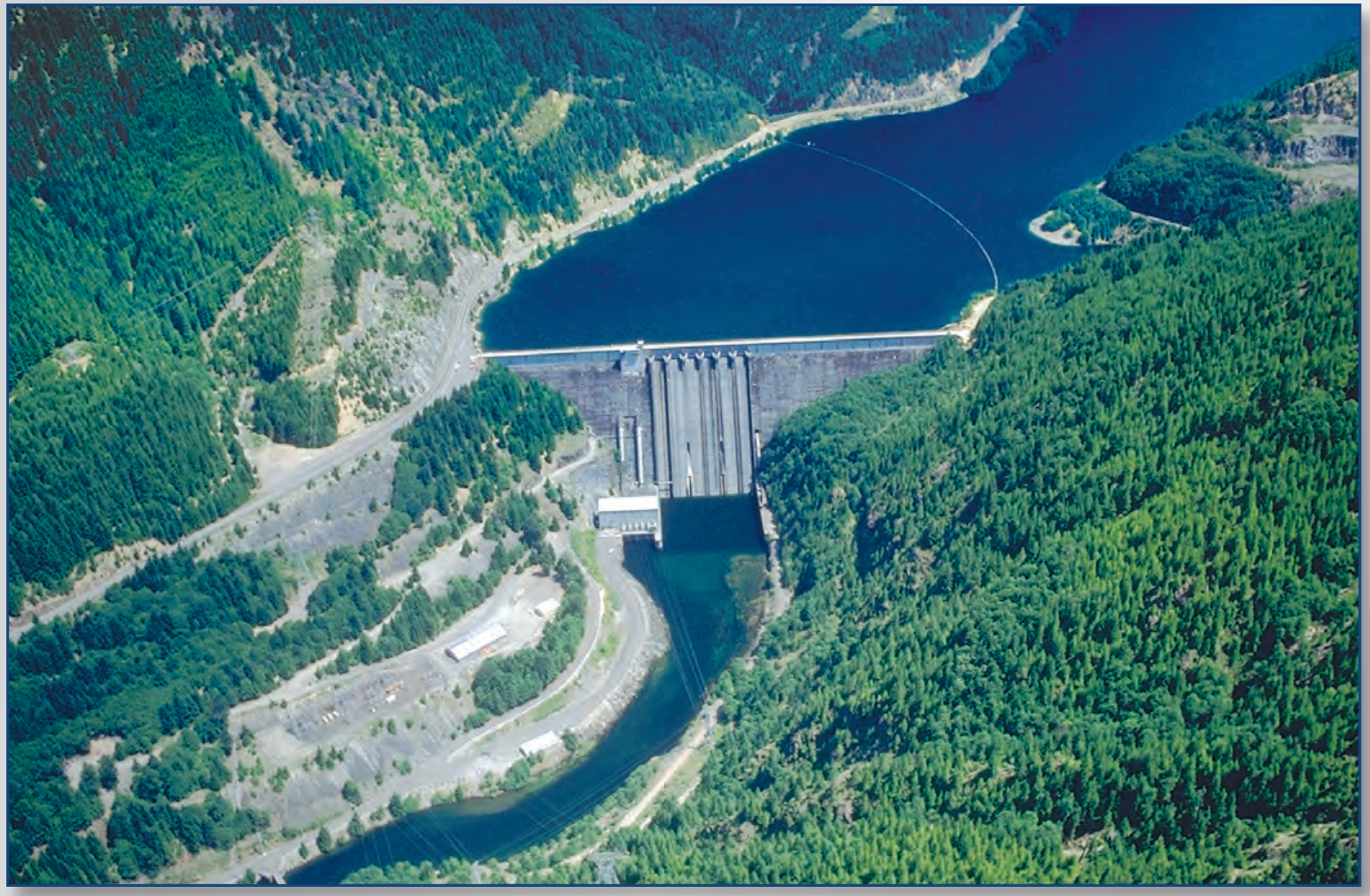

Scientific Investigations Report 2010-5153 
Cover: Photograph of Detroit Dam on the North Santiam River.

Back Cover: Photographs, from left to right, by row:

Top row

Big Cliff Dam on the North Santiam River

Detroit Dam on the North Santiam River

Foster Dam on the South Santiam River

Green Peter Dam on the Middle Santiam River

\section{2nd row:}

Blue River Dam on Blue River

Cougar Dam on the South Fork McKenzie River

Fall Creek Dam on Fall Creek

Dexter Dam on the Middle Fork Willamette River

\section{3rd row:}

Lookout Point Dam on the Middle Fork Willamette River Hills Creek Dam on the Middle Fork Willamette River

Dorena Dam on the Row River

Cottage Grove Dam on the Coast Fork Willamette River

Bottom row:

Fern Ridge Dam on the Long Tom River

River Mill Dam on the Clackamas River

All photographs except that of River Mill Dam are from the U.S. Army Corps of Engineers' Digital Visual Library at https://eportal.usace.army.mil/sites/DVL/

Photograph of River Mill Dam is from Portland General Electric.

All photographs are used here with the permission of the source entities. 


\title{
Thermal Effects of Dams in the Willamette River Basin, Oregon
}

\author{
By Stewart A. Rounds
}

Prepared in cooperation with the U.S. Army Corps of Engineers and the Oregon Association of Clean Water Agencies

Scientific Investigations Report 2010-5153 


\section{U.S. Department of the Interior \\ KEN SALAZAR, Secretary \\ U.S. Geological Survey \\ Marcia K. McNutt, Director}

U.S. Geological Survey, Reston, Virginia: 2010

For more information on the USGS - the Federal source for science about the Earth, its natural and living resources, natural hazards, and the environment, visit http://www.usgs.gov or call 1-888-ASK-USGS

For an overview of USGS information products, including maps, imagery, and publications, visit http://www.usgs.gov/pubprod

To order this and other USGS information products, visit http://store.usgs.gov

Any use of trade, product, or firm names is for descriptive purposes only and does not imply endorsement by the U.S. Government.

Although this report is in the public domain, permission must be secured from the individual copyright owners to reproduce any copyrighted materials contained within this report.

Suggested citation:

Rounds, S.A., 2010, Thermal effects of dams in the Willamette River basin, Oregon: U.S. Geological Survey Scientific Investigations Report 2010-5153, 64 p. 


\section{Contents}

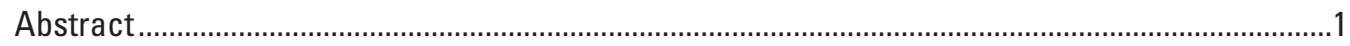

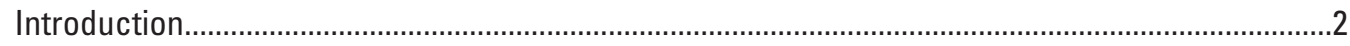

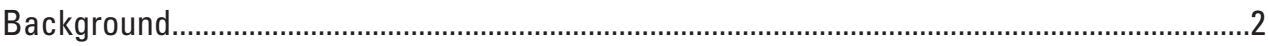

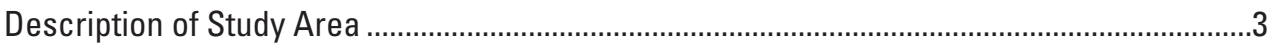

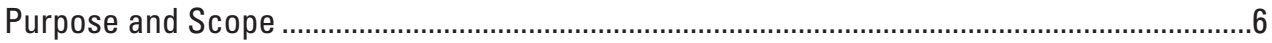

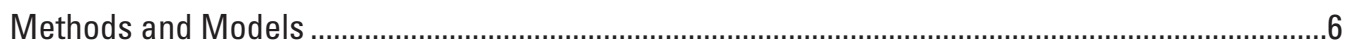

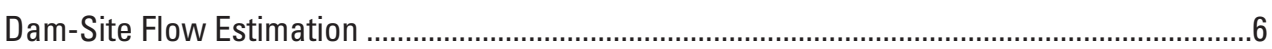

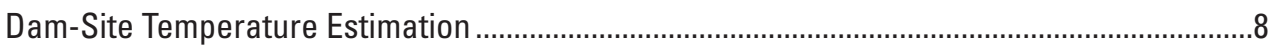

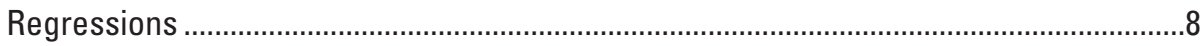

Mass and Energy Balances ................................................................................... 10

Downstream Warming ........................................................................................... 10

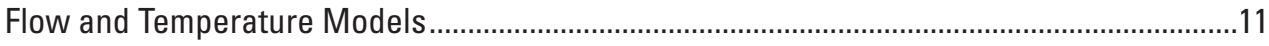

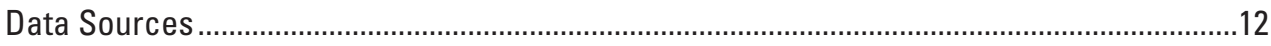

Thermal Effects of Dams in the Willamette River Basin ...............................................................13

Without-Dam Flow Estimates at Dam Sites...................................................................

Without-Dam Temperature Estimates at Dam Sites ………...............................................15

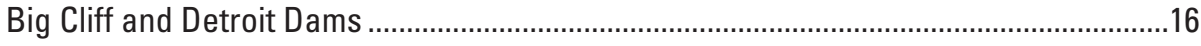

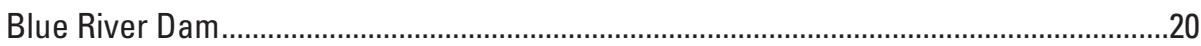

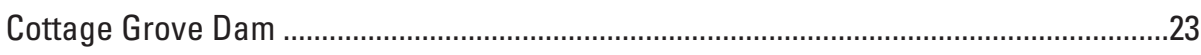

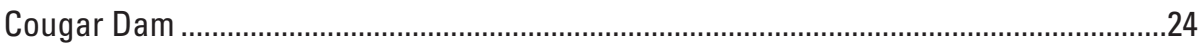

Dexter and Lookout Point Dams ......................................................................................

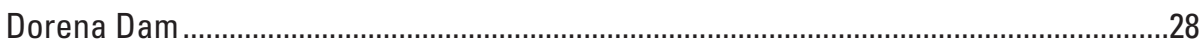

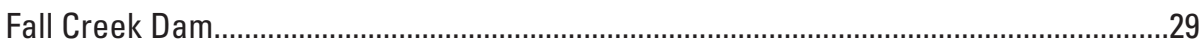

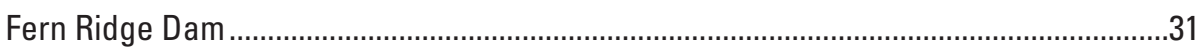

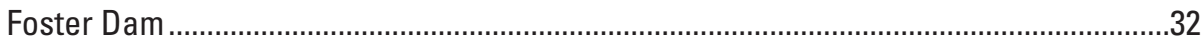

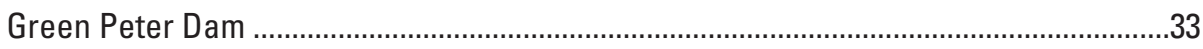

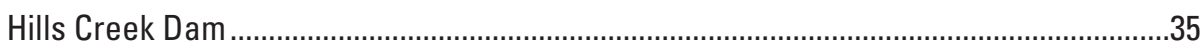

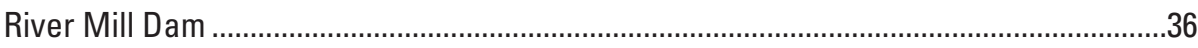

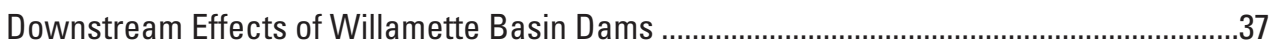

Downstream Flows ................................................................................................

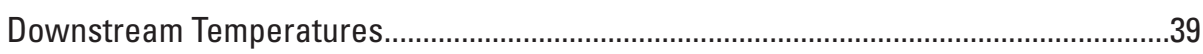

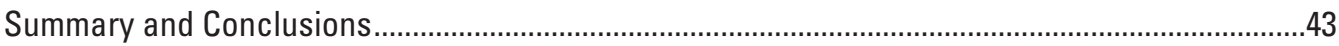

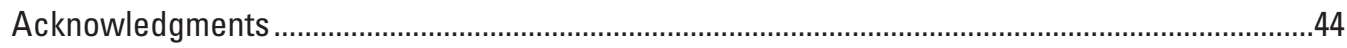

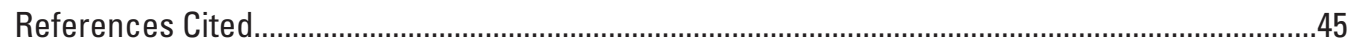

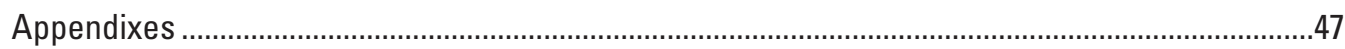

Appendix A. Graphs of Without-Dam Flow Estimates at Willamette River Basin

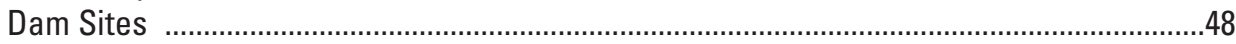

Appendix B. Time/Distance Color Maps Showing the Downstream Thermal Effects of Willamette River Basin Dams

Appendix C. Graphs of Modeled Temperature Distributions Downstream of Willamette River Basin Dam Sites. 


\section{Figures}

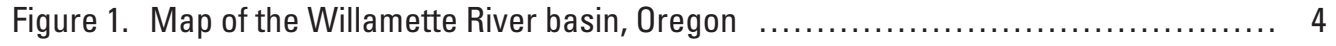

Figure 2. Map of major physiographic regions in the Willamette River basin, Oregon....... 5

Figure 3. Diagram showing imposed seasonal variation in the estimated correction for evaporative losses from Willamette River basin reservoirs, Oregon.....

Figure 4. Flow chart showing process for estimating without-dam water temperatures at dam sites in the Willamette River basin, Oregon

Figure 5. Graph showing measured and estimated streamflow for conditions with and without upstream dams in the Middle Fork Willamette River at Dexter Dam, just downstream of Lookout Point Dam in the Willamette River basin, Oregon, 2001-02

Figure 6. Graphs showing measured and estimated water temperatures for conditions with and without upstream dams at the Big Cliff / Detroit, Blue River, and Cottage Grove dam sites in the Willamette River basin, Oregon, 2001-02. ...

Figure 7. Graphs showing cumulative frequency curves of measured and estimated water temperatures for conditions with and without upstream dams at the Big Cliff dam site in the Williamette River basin, Oregon, 2001-02

Figure 8. Graphs showing correlation of water temperatures for Blue River (BR) and Blowout Creek (BC) in the Willamette River basin, Oregon, for a period in mid-summer of 2000

Figure 9. Graphs showing measured and estimated water temperatures for conditions with and without upstream dams at the Cougar, Dexter / Lookout Point, and Dorena dam sites in the Willamette River basin, Oregon, 2001-02

Figure 10. Graphs showing measured and estimated water temperatures for conditions with and without upstream dams at the Fall Creek, Fern Ridge, and Foster dam sites in the Willamette River basin, Oregon, 2001-02

Figure 11. Graph showing measured heating effect of Fern Ridge Lake in the Willamette River basin, based on temperature measurements upstream and downstream of the lake

Figure 12. Graphs showing measured and estimated water temperatures for conditions with and without upstream dams at the Green Peter, Hills Creek, and River Mill dam sites in the Willamette River basin, Oregon, 2001-02....

Figure 13. Graphs showing measured daily mean streamflow at USGS gaging stations on the Willamette River at Albany and at Salem

Figure 14. Graph showing simulated streamflow in the Willamette River at Albany and at Salem for conditions with and without upstream dams in the Willamette River basin, Oregon, April-0ctober 2002

Figure 15. Time/distance color map showing modeled downstream thermal effects of dams on the entire Willamette River, Oregon, June-October 2001 and April-October 2002

Figure 16. Cumulative frequency plot $(A)$ and histograms $(B, C)$ of modeled $7 \mathrm{dADM}$ temperatures for conditions with and without dams in the Willamette River downstream of the confluence of the Coast Fork and Middle Fork Willamette Rivers, Oregon, June-0ctober 2001-02. 


\section{Tables}

Table 1. Willamette River basin dams included in this study ........................... 3

Table 2. Evaporation rates from selected reservoirs owned and operated by the U.S. Army Corps of Engineers in the Willamette River basin, Oregon

Table 3. Minimum and maximum streamflows for conditions with and without upstream dams at 12 dam sites in the Willamette River basin, Oregon, 2001-02 ... 14

Table 4. Measured with-dam and estimated without-dam annual maximum water temperatures as measured by the 7-day average of the daily maximum at selected dam sites in the Willamette River basin, Oregon, 2001-02

Table 5. Maximum estimated error ranges for the without-dam water-temperature estimates at selected dam sites in the Willamette River basin, Oregon

\section{Conversion Factors, Datums, and Abbreviations and Acronyms}

\section{Conversion Factors}

Inch/Pound to SI

\begin{tabular}{lcl}
\hline \multicolumn{1}{c}{ Multiply } & \multicolumn{1}{c}{ By } & \multicolumn{1}{c}{ To obtain } \\
\hline inch (in.) & 2.54 & centimeter $(\mathrm{cm})$ \\
foot $(\mathrm{ft})$ & 0.3048 & meter $(\mathrm{m})$ \\
mile $(\mathrm{mi})$ & 1.609 & kilometer $(\mathrm{km})$ \\
acre & 4,047 & square meter $\left(\mathrm{m}^{2}\right)$ \\
acre & 0.004047 & square kilometer $\left(\mathrm{km}^{2}\right)$ \\
square mile $\left(\mathrm{mi}^{2}\right)$ & 2.590 & square kilometer $\left(\mathrm{km}^{2}\right)$ \\
acre-foot $(\mathrm{acre}-\mathrm{ft})$ & 1,233 & cubic meter $\left(\mathrm{m}^{3}\right)$ \\
cubic foot per second $\left(\mathrm{ft}^{3} / \mathrm{s}\right)$ & 0.02832 & cubic meter $p e r$ second $\left(\mathrm{m}^{3} / \mathrm{s}\right)$ \\
\hline
\end{tabular}

Temperature in degrees Celsius $\left({ }^{\circ} \mathrm{C}\right)$ may be converted to degrees Fahrenheit $\left({ }^{\circ} \mathrm{F}\right)$ as follows:

$$
{ }^{\circ} \mathrm{F}=\left(1.8 \times{ }^{\circ} \mathrm{C}\right)+32
$$

Temperature in degrees Fahrenheit $\left({ }^{\circ} \mathrm{F}\right)$ may be converted to degrees Celsius $\left({ }^{\circ} \mathrm{C}\right)$ as follows:

$$
{ }^{\circ} \mathrm{C}=\left({ }^{\circ} \mathrm{F}-32\right) / 1.8
$$

\section{Datums}

Vertical coordinate information is referenced to the North American Vertical Datum of 1988 (NAVD 88).

Horizontal coordinate information is referenced to the North American Datum of 1983 (NAD 83). 


\section{Abbreviations and Acronyms}

\begin{tabular}{ll}
\hline 7dADM & 7-day running average of the daily maximum \\
FERC & Federal Energy Regulatory Commission \\
ODEO & Oregon Department of Environmental Quality \\
NTP & Natural Thermal Potential \\
PGE & Portland General Electric \\
PSU & Portland State University \\
RM & river mile \\
TMDL & Total Maximum Daily Load \\
USACE & U.S. Army Corps of Engineers \\
USGS & U.S. Geological Survey \\
\hline
\end{tabular}




\title{
Thermal Effects of Dams in the Willamette River Basin, Oregon
}

\author{
By Stewart A. Rounds
}

\section{Abstract}

Methods were developed to assess the effects of dams on streamflow and water temperature in the Willamette River and its major tributaries. These methods were used to estimate the flows and temperatures that would occur at 14 dam sites in the absence of upstream dams, and river models were applied to simulate downstream flows and temperatures under a no-dams scenario. The dams selected for this study include 13 dams built and operated by the U.S. Army Corps of Engineers (USACE) as part of the Willamette Project, and 1 dam on the Clackamas River owned and operated by Portland General Electric (PGE). Streamflows in the absence of upstream dams for 2001-02 were estimated for USACE sites on the basis of measured releases, changes in reservoir storage, a correction for evaporative losses, and an accounting of flow effects from upstream dams. For the PGE dam, no-project streamflows were derived from a previous modeling effort that was part of a dam-relicensing process. Without-dam streamflows were characterized by higher peak flows in winter and spring and much lower flows in late summer, as compared to with-dam measured flows.

Without-dam water temperatures were estimated from measured temperatures upstream of the reservoirs (the USACE sites) or derived from no-project model results (the PGE site). When using upstream data to estimate without-dam temperatures at dam sites, a typical downstream warming rate based on historical data and downstream river models was applied over the distance from the measurement point to the dam site, but only for conditions when the temperature data indicated that warming might be expected. Regressions with measured temperatures from nearby or similar sites were used to extend the without-dam temperature estimates to the entire 2001-02 time period. Without-dam temperature estimates were characterized by a more natural seasonal pattern, with a maximum in July or August, in contrast to the measured patterns at many of the tall dam sites where the annual maximum temperature typically occurred in September or October. Without-dam temperatures also tended to have more daily variation than with-dam temperatures.
Examination of the without-dam temperature estimates indicated that dam sites could be grouped according to the amount of streamflow derived from high-elevation, spring-fed, and snowmelt-driven areas high in the Cascade Mountains (Cougar, Big Cliff/Detroit, River Mill, and Hills Creek Dams: Group A), as opposed to flow primarily derived from lower-elevation rainfall-driven drainages (Group B). Annual maximum temperatures for Group A ranged from 15 to $20^{\circ} \mathrm{C}$, expressed as the 7-day average of the daily maximum (7dADM), whereas annual maximum 7dADM temperatures for Group B ranged from 21 to $25^{\circ} \mathrm{C}$. Because summertime stream temperature is at least somewhat dependent on the upstream water source, it was important when estimating without-dam temperatures to use correlations to sites with similar upstream characteristics. For that reason, it also is important to maintain long-term, year-round temperature measurement stations at representative sites in each of the Willamette River basin's physiographic regions.

Streamflow and temperature estimates downstream of the major dam sites and throughout the Willamette River were generated using existing CE-QUAL-W2 flow and temperature models. These models, originally developed for the Willamette River water-temperature Total Maximum Daily Load process, required only a few modifications to allow them to run under the greatly reduced without-dam flow conditions. Model scenarios both with and without upstream dams were run. Results showed that Willamette River streamflow without upstream dams was reduced to levels much closer to historical pre-dam conditions, with annual minimum streamflows approximately one-half or less of dam-augmented levels. Thermal effects of the dams varied according to the time of year, from cooling in mid-summer to warming in early autumn. Thermal effects diminished with increasing distance downstream, from as much as $6{ }^{\circ} \mathrm{C}$ or more at most of the taller dam sites to a level typically less than $1^{\circ} \mathrm{C}$ downstream of the Santiam River confluence and less than $0.5^{\circ} \mathrm{C}$ downstream of the Clackamas River confluence. Modeled without-dam temperatures in the Willamette River had a higher maximum and a lower minimum than modeled withdam temperatures for the June-October modeled time period. Upstream dams have a substantial and measurable effect on streamflow and water temperature, both at the dam sites and downstream throughout the entire Willamette River. 


\section{Introduction}

\section{Background}

It is widely recognized that dams have important effects on streamflow, water temperature, and fisheries (Collier and others, 1996). Often managed to provide protection from floods, reservoirs capture large inflows and release them over a longer time period, thereby decreasing annual peak flows. During dry seasons, reservoir releases for navigation, irrigation, municipal uses, and flow augmentation increase the annual minimum streamflow above pre-dam levels. Because deep reservoirs tend to thermally stratify in summer and keep less-dense warmer water at the surface, releases from deep in a reservoir typically are colder in mid-summer compared to nearby rivers without dams. Similarly, when a reservoir is drawn down in autumn to provide storage for flood control, the warm surface layer can be brought down to the outlet elevation, resulting in warmer-than-normal discharges. These alterations in streamflow and seasonal temperature patterns downstream of dams can create problems for fish related to the timing of migration, spawning, and egg hatching (Caissie, 2006). Dams also can be a barrier to fish passage, further disrupting the patterns and success of migration and spawning.

The Willamette River basin in northwestern Oregon has a system of dams that were built to provide flood control, power production, storage for agricultural and municipal uses, flow augmentation for downstream navigation, and recreation. The U.S. Army Corps of Engineers (USACE) operates the largest system of dams in the basin, totaling 13 storage and flow-regulating dams. Portland General Electric (PGE) owns and operates several hydropower projects, many of which are located in the Clackamas River basin, a tributary to the Willamette River. Fish passage and downstream thermal effects have long been an issue for many of these dams. A retrofit at the USACE Cougar Dam on the South Fork (SF) McKenzie River was completed in 2005 to allow for better control of downstream temperatures; the resulting seasonal temperature pattern now is more natural and has improved conditions for fish spawning and fry emergence in the reach downstream of the dam (Greg Taylor, U.S. Army Corps of Engineers, oral commun., 2010).

As a result of many factors including the dams, winter steelhead (Oncorhynchus mykiss) and Chinook salmon (Oncorhynchus tshawytscha) were listed as threatened under the Federal Endangered Species Act in March 1999. To protect these species, the National Marine Fisheries Service issued a "Biological Opinion" in July 2008, providing guidelines and timetables that address fish passage and the flow and temperature alterations caused by the dams, among other recommendations (National Marine Fisheries Service, 2008). Some of the recommendations already are being implemented, such as modified operations at the USACE Detroit Dam to better manage downstream temperatures.
Recognizing that water temperature is a critical factor affecting the survival and viability of anadromous fish, the Oregon Department of Environmental Quality (ODEQ) created a maximum water-temperature standard under the authority of the Federal Clean Water Act. To protect fish and aquatic resources and meet water-quality standards in the Willamette River and several of its largest tributaries, ODEQ issued a water-temperature Total Maximum Daily Load (TMDL) in September 2006 (Oregon Department of Environmental Quality, 2006a, 2006b). Relying on models and data, ODEQ attempted to quantify the thermal effects of several important factors on the river system. The TMDL specified heat wasteload allocations for point-source dischargers, called for revegetation of degraded riparian zones, and established temperature targets downstream of the major dams. The cumulative heating effects of point-source discharges and decreased riparian shading were determined using detailed calibrated models. Models were not available, however, to quantify the thermal effects of the major dams at dam sites, and the analysis of those effects in the TMDL was limited primarily to a comparison of measured temperatures upstream and downstream of the reservoirs.

Thermal effects downstream of tall dams can be large and commonly have characteristic seasonal and spatial patterns. These patterns and characteristics have been described and modeled by Risley and others (2010) for several idealized stream, reservoir, and climate conditions, demonstrating that altered release temperatures have an effect that dissipates with downstream distance, but that flow modifications have an increasing thermal effect downstream. In the Willamette River basin, a simple comparison of measured temperatures upstream and downstream of Detroit and Cougar Dams reveals temperature changes as much as $6{ }^{\circ} \mathrm{C}$ (cooler downstream in mid-summer, warmer in October) prior to actions taken to mitigate such effects (Oregon Department of Environmental Quality, 2006b; Rounds, 2007; Sullivan and others, 2007). If dam releases are not managed to provide for some daily variation in water temperature, a downstream pattern in the daily range of water temperature also can develop, with distinct nodes of minimal daily variation at daily travel-time distances (Lowney, 2000). These downstream thermal effects, and their mitigation through changes in dam operations, can be simulated accurately with models. Examples from the Willamette River basin include models of the reservoirs impounded by Detroit Dam and Scoggins Dam, which were used to evaluate how changes in dam operation can be used to meet target downstream water temperatures (Sullivan and Rounds, 2006; Sullivan and others, 2007). The downstream thermal effects of the Cougar Dam retrofit have been tracked downstream using the Willamette River TMDL models (Rounds, 2007). 


\section{Description of Study Area}

The Willamette River flows for $187 \mathrm{mi}$ from south to north past some of the largest cities in northwestern Oregon, including Eugene, Corvallis, Albany, Salem, and Portland (fig. 1). The river basin covers an area of approximately $11,500 \mathrm{mi}^{2}$ and is home to more than 2.6 million people, about 70 percent of the population of Oregon (U.S. Census Bureau, 2008). Bounded by the Cascade Range to the east and the Coast Range to the west, the basin has a modified maritime climate characterized by cool, wet winters and warm, dry summers. Eastward-moving Pacific storms deliver plentiful rain as well as snow in the mountains during the wet winter season; about 70-80 percent of the annual precipitation falls between October and March, and less than 5 percent in July and August (Wentz and others, 1998). Rainfall can total as much as $130 \mathrm{in} / \mathrm{yr}$ in the mountains, but typically 35-40 in/yr in the valley lowlands. Approximately 70 percent of the basin is forested and 20 percent, primarily in the valley bottom, is agricultural land (Hulse and others, 2002).

Streamflow in the Willamette River follows seasonal rainfall patterns, with the highest flows during winter storms and the lowest flows in late summer. A system of floodcontrol dams moderates annual peak flows. The mean annual peak flow in the Willamette River at Salem (USGS station 14191000) for the 1970-2008 post-dam time period was $111,000 \mathrm{ft}^{3} / \mathrm{s}$ but as high as $244,000 \mathrm{ft}^{3} / \mathrm{s}$ in 1996 . Annual low flows are augmented by releases from upstream reservoirs during summer, with typical target minimum flows of $6,000 \mathrm{ft}^{3} / \mathrm{s}$ at Salem and 4,000 $\mathrm{ft}^{3} / \mathrm{s}$ at Albany.

Dams in the Willamette River basin are owned and operated by various entities and for a wide range of purposes. The USACE operates a system of 13 dams, including the tallest dams (463 and $452 \mathrm{ft}$, Detroit and Cougar Dams, respectively) and the largest storage reservoirs (about 455,000 acre-ft, Detroit and Lookout Point Dams) in the basin (table 1). On the Clackamas River, PGE operates a series of dams and diversions for power generation; the most downstream dam is River Mill Dam.

Streamflow and temperature characteristics in Willamette Basin streams are linked to the physiographic region of the stream's headwaters. The basin has four major physiographic regions distinguished by their predominant location, elevation, and geologic characteristics (fig. 2). Streams with significant source areas in the High Cascades derive their flow from rainfall and snowmelt, where relatively young and permeable volcanic rocks conduct snowmelt to large spring complexes that provide cold and consistent flows year round (Conlon and others, 2005). In contrast, streams in the Western Cascades and the Coast Range are more driven by rainfall and lack the large spring complexes of the High Cascades, resulting in more variable flows and lower flows and warmer temperatures in summer (Tague and others, 2007).

Table 1. Willamette River basin dams included in this study.

[Storage is the reservoir volume at full pool elevation. USACE, U.S. Army Corps of Engineers; PGE, Portland General Electric; ft, feet; na, not available; - , none]

\begin{tabular}{lllcrrc}
\hline \multicolumn{1}{c}{ Dam name } & \multicolumn{1}{c}{ Location } & Owner & $\begin{array}{c}\text { Year } \\
\text { completed }\end{array}$ & $\begin{array}{c}\text { Height } \\
\text { (ft) }\end{array}$ & $\begin{array}{r}\text { Storage } \\
\text { (acre-ft) }\end{array}$ & $\begin{array}{c}\text { Upstream } \\
\text { dams }\end{array}$ \\
\hline Big Cliff Dam & North Santiam River & USACE & 1953 & 191 & 6,450 & Detroit \\
Blue River Dam & Blue River & USACE & 1969 & 270 & 89,500 & - \\
Cottage Grove Dam & Coast Fork Willamette River & USACE & 1942 & 95 & 32,900 & - \\
Cougar Dam & South Fork McKenzie River & USACE & 1963 & 452 & 219,000 & - \\
Detroit Dam & North Santiam River & USACE & 1953 & 463 & 455,100 & - \\
Dexter Dam & Middle Fork Willamette River & USACE & 1954 & 93 & na & Lookout Point, Hills Creek \\
Dorena Dam & Row River & USACE & 1949 & 145 & 77,600 & - \\
Fall Creek Dam & Fall Creek & USACE & 1966 & 180 & 125,000 & - \\
Fern Ridge Dam & Long Tom River & USACE & 1941 & 44 & 116,800 & - \\
Foster Dam & South Santiam River & USACE & 1968 & 126 & 60,700 & Green Peter \\
Green Peter Dam & Middle Santiam River & USACE & 1968 & 327 & 428,100 & - \\
Hills Creek Dam & Middle Fork Willamette River & USACE & 1961 & 304 & 355,500 & - \\
Lookout Point Dam & Middle Fork Willamette River & USACE & 1954 & 276 & 455,800 & Hills Creek \\
River Mill Dam & Clackamas River & PGE & 1911 & 101 & na & several \\
\hline
\end{tabular}




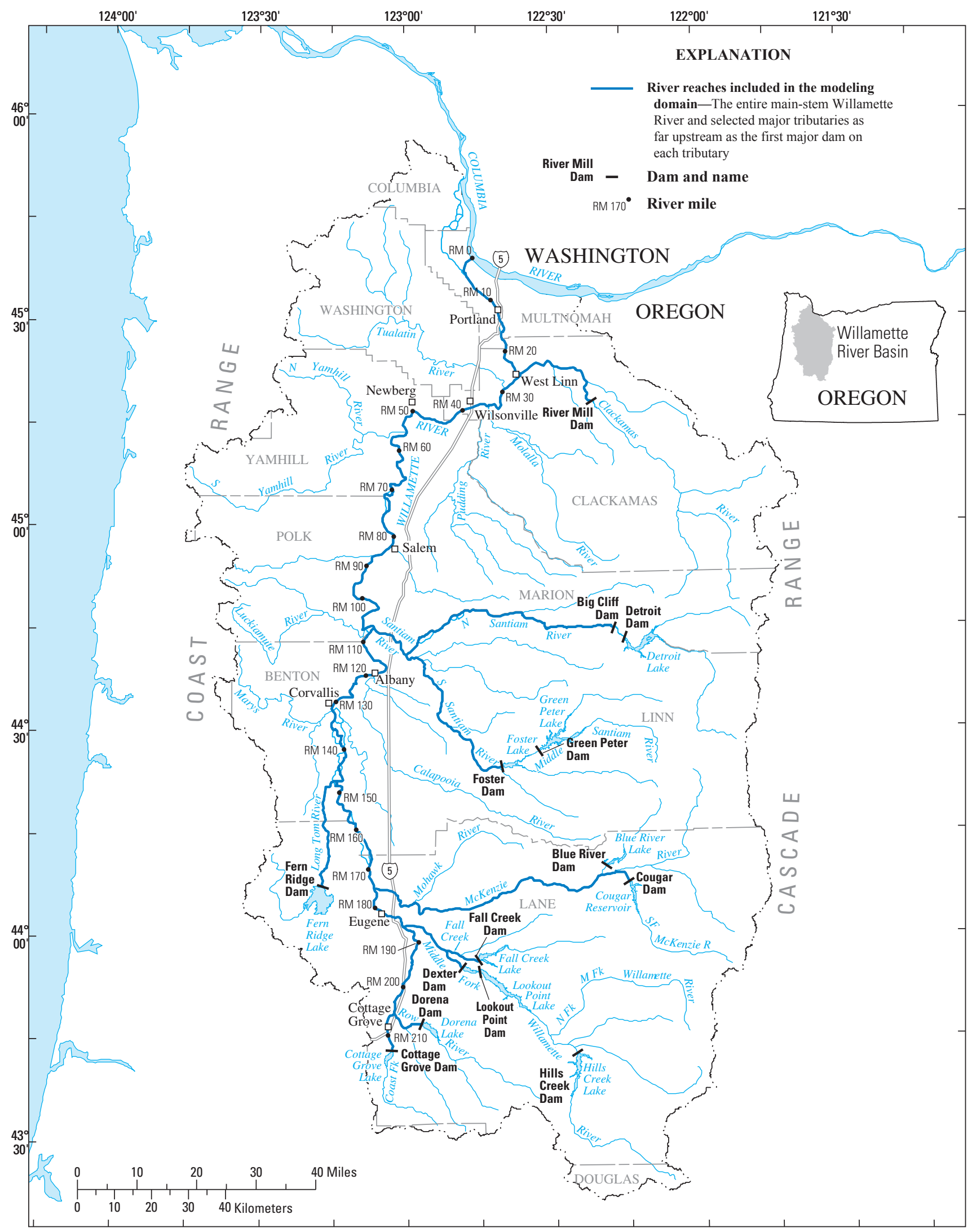

Base map modified from U.S. Geological Survey and other digital data sets (1:2,000,000; 1:100,000). Projection: Oregon Lambert Conformal Conic, NAD1983, NAVD1988.

Figure 1. The Willamette River basin, Oregon (reproduced from Rounds, 2007). 


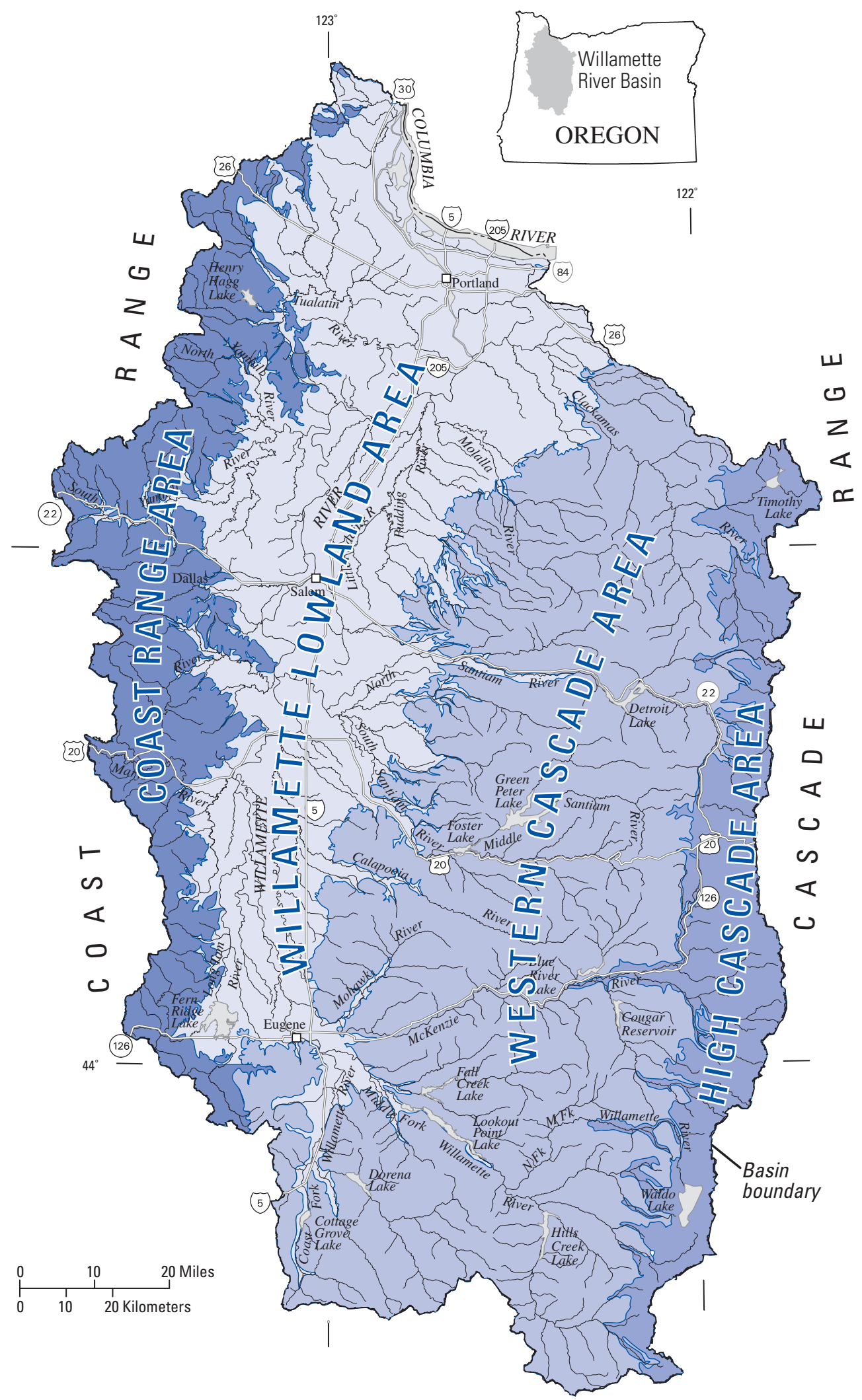

Figure 2. Major physiographic regions in the Willamette River basin, Oregon (modified from Conlon and others, 2005). 
Temperatures in Willamette Basin streams generally follow the seasonal climate pattern, have characteristics derived from their morphology and physiographic source area, and are affected by several anthropogenic influences such as upstream dams, water withdrawals, point-source discharges, and modifications to riparian shading. ODEQ's analysis for the Willamette River water-temperature TMDL showed that cumulative heating effects from point sources amounted to less than $0.2{ }^{\circ} \mathrm{C}$ and that loss of riparian shading accounted for a warming of $0.5-1.0^{\circ} \mathrm{C}$ (Oregon Department of Environmental Quality, 2006b). Downstream of tall dams, the temperature can be modified by as much as $6-8{ }^{\circ} \mathrm{C}$, both warmer and cooler depending on the time of year (Sullivan and others, 2007). The thermal effects of the dams diminish with distance downstream, as demonstrated by an analysis of the effects of the retrofit to Cougar Dam, where near-dam effects were as large as $6.0-6.5^{\circ} \mathrm{C}$, but decreased to a fraction of a degree in the Willamette River because of dilution and heat exchange with the atmosphere (Rounds, 2007).

\section{Purpose and Scope}

Dams have a significant effect on downstream flows and temperatures in the Willamette River basin (Oregon Department of Environmental Quality, 2006b; Rounds, 2007). The primary purpose of this study was to quantify the thermal effects of Willamette River basin dams, concentrating on the following two objectives:

- Develop and apply methods to estimate the water temperatures that would occur at selected Willamette River basin dam sites in the absence of those dams, and

- Simulate the downstream flow and thermal effects of Willamette River basin dams.

To take advantage of a suite of existing CE-QUAL-W2 flow and water-temperature models of the Willamette River and its major tributaries, the time period for this study was aligned with the calibrated time periods for those modelsspring through autumn in 2001 and 2002. Although the models were run to determine downstream effects only for June through October 2001 and April through October 2002, without-dam water temperatures at the dam sites were estimated for the entire years of 2001 and 2002.

This study focused on 13 USACE dams that make up the Willamette Project in northwestern Oregon, as well as the combined effects of multiple dams on the Clackamas River, a tributary to the lower Willamette River (fig. 1, table 1). Other dams in the Willamette River basin, such as Scoggins Dam in the Tualatin River basin and the Carmen-Smith Project in the upper McKenzie River basin, were not included in this analysis because these dams and tributary reaches were not included in the models used to assess water-temperature issues for the Willamette River water-temperature TMDL; these dams also are small enough and far enough upstream that their effects on Willamette River flows and temperatures are minimal. Downstream effects were simulated only for the reaches included in the TMDL models. Where two or more dams are located on the same tributary, such as Green Peter and Foster Dams in the South Santiam River basin, the downstream effects were simulated starting at the most downstream dam only, although without-dam water temperatures still were estimated for the upstream dam sites.

In addition to water temperatures, without-dam streamflows were estimated at each of the dam sites. Those flow estimates were not a major focus of the study, but were a critical model input for the simulation of downstream thermal effects. Although an assessment of the flow effects of the dams was not a major objective of this study, those effects are substantial and the results provide useful data for future resource management.

Finally, the methods and techniques documented in this report are not meant to provide definitive equations for estimating without-dam water temperatures. Instead, the methods are meant to illustrate the types of estimation methods that can be used and to provide reasonable starting points for similar analyses or models. In the absence of more detailed models of water temperature for a without-dams condition, the methods documented in this report can be used to produce useful estimates.

\section{Methods and Models}

Several methods were used to estimate the flow and water temperature conditions that would occur at the target dam sites in the absence of those dams, and then track those effects downstream.

\section{Dam-Site Flow Estimation}

The downstream flow and thermal effects of Willamette River basin dams cannot be modeled without first estimating the flows that would occur at the dam sites in the absence of the dams. In some cases, flow estimates also were needed to help estimate without-dam water temperatures at the dam sites, particularly when more than one reservoir was located on the same tributary. One method was used to estimate flows at the USACE dam sites, and a different method was used to estimate flows at the River Mill dam site on the Clackamas River. 
For the USACE dam sites, without-dam flows were computed using net inflow estimates that are routinely calculated by USACE from measured dam releases and measured changes in reservoir storage. To estimate the actual total inflow rate to each reservoir, it was necessary only to adjust the net inflow estimates to account for evaporative losses in the reservoir. (The effects of precipitation are included in the analysis through an assumption that any rainfall collected by the surface of the reservoir would result in a similar amount of streamflow in the absence of that reservoir.) Evaporation rate measurements at each reservoir were available from USACE (see section, "Data Sources"). The maximum evaporation rates were measured in July and ranged from 4.36 to $6.22 \mathrm{in} / \mathrm{mo}$; minimum evaporation rates were assumed to be $1.00 \mathrm{in} / \mathrm{mo}$ (table 2). For a reservoir with a large surface area such as Fern Ridge Lake (9,000 acres at full pool), the maximum evaporative loss is substantial $\left(62.2 \mathrm{ft}^{3} / \mathrm{s}\right)$ and can be as large as the incoming streamflow at times. Evaporative losses were assumed to vary in a smooth sinusoidal-like fashion from a minimum in winter to a maximum in summer as in figure 3. Evaporation adjustments for the re-regulating reservoirs (Dexter and Big Cliff) were negligible and therefore were not included in the without-dam flow estimates.

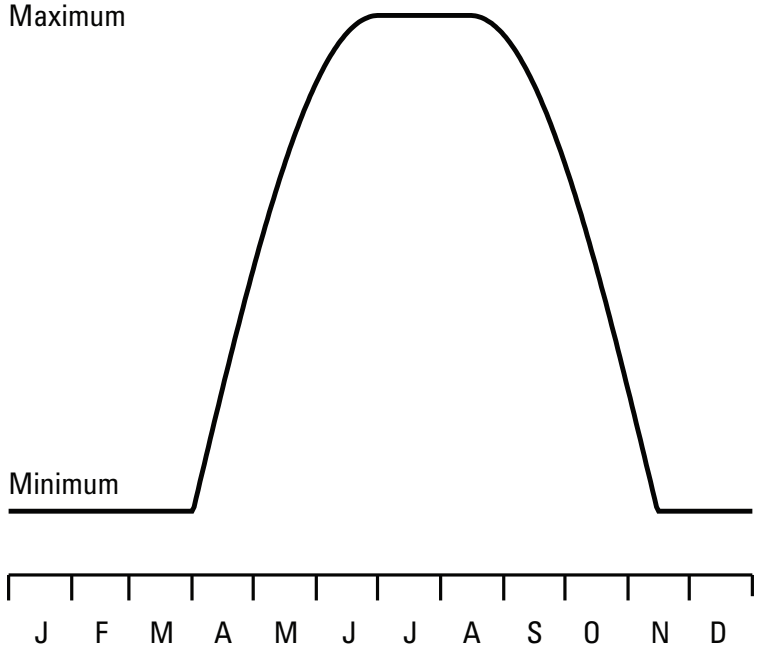

Figure 3. Imposed seasonal variation in the estimated correction for evaporative losses from Willamette River basin reservoirs, Oregon. Maximum losses were between July 1 and August 15. Minimum losses were prior to April 1 and after November 15.

Table 2. Evaporation rates from selected reservoirs owned and operated by the U.S. Army Corps of Engineers in the Willamette River basin, Oregon.

[USACE, U.S. Army Corps of Engineers; maximum evaporation rates from July measurements by USACE; minimum evaporation rates were assumed]

\begin{tabular}{|c|c|c|c|c|c|}
\hline \multirow[t]{2}{*}{ Reservoir } & \multicolumn{2}{|c|}{$\begin{array}{l}\text { Evaporation rate } \\
\text { (inches per month) }\end{array}$} & \multirow{2}{*}{$\begin{array}{l}\text { Full-pool area } \\
\text { (acres) }\end{array}$} & \multicolumn{2}{|c|}{$\begin{array}{c}\text { Evaporative loss } \\
\text { (cubic feet per second) }\end{array}$} \\
\hline & Maximum & Minimum & & Maximum & Minimum \\
\hline Blue River & 4.36 & 1.00 & 1,009 & 6.0 & 1.4 \\
\hline Cottage Grove & 4.49 & 1.00 & 1,156 & 7.0 & 1.6 \\
\hline Cougar & 5.53 & 1.00 & 1,280 & 9.6 & 1.7 \\
\hline Detroit & 4.59 & 1.00 & 3,500 & 21.8 & 4.7 \\
\hline Dorena & 4.75 & 1.00 & 1,749 & 11.3 & 2.4 \\
\hline Fall Creek & 4.94 & 1.00 & 1,820 & 12.2 & 2.5 \\
\hline Fern Ridge & 5.10 & 1.00 & 9,000 & 62.2 & 12.2 \\
\hline Foster & 4.65 & 1.00 & 1,220 & 7.7 & 1.7 \\
\hline Green Peter & 4.82 & 1.00 & 3,720 & 24.3 & 5.0 \\
\hline Hills Creek & 6.22 & 1.00 & 2,735 & 23.1 & 3.7 \\
\hline Lookout Point & 4.55 & 1.00 & 4,360 & 26.9 & 5.9 \\
\hline
\end{tabular}


The Clackamas River has multiple dams and hydropower diversions, which complicates the process of estimating streamflow in the absence of those features. For this river system, however, a model had been constructed for PGE's dam relicensing process, and one of the model scenarios was a simulation of conditions in the absence of the dams and hydropower projects. That model scenario was provided to ODEQ and was used in support of the Willamette River temperature TMDL (Oregon Department of Environmental Quality, 2006b). The modeled "no-project" flows were used as no-dam flow estimates for the River Mill dam site on the Clackamas River for the period in 2001 that overlapped the period of interest for this study. No-dam flows after September 30,2001 , were estimated through a correlation of the available no-project flows with estimated no-dam flows at Big Cliff Dam on the North Santiam River.

\section{Dam-Site Temperature Estimation}

The methods used to estimate without-dam water temperatures at each of the dam sites of interest varied depending on the availability of upstream data and the presence of additional dams upstream. The flow chart in figure 4 illustrates the general process. For a reservoir with only one major inflow, no upstream reservoirs, and a complete record of upstream water temperature, the upstream water temperatures simply were adjusted to account for any warming that would occur during summer as the water travels downstream to the dam site. If the upstream water-temperature dataset was incomplete, or if data were only available for a different time period, then regression techniques were applied using measured water temperatures from nearby or similar streams to estimate temperatures for the period of interest. For reservoirs with more than one major inflow, energy and mass balances were applied to generate temperature estimates at the confluence of those inflows in the reservoir. Finally, if more than one dam is located on the same major tributary, such as Green Peter and Foster Dams in the South Santiam River basin, then the estimation procedures were applied to the most upstream dam first and then to the dam(s) downstream.

\section{Regressions}

Regression techniques were used to estimate water temperatures at sites upstream of reservoirs if the available datasets did not fully correspond to the period of interest. The available water-temperature data were correlated with water-temperature data from a nearby or similar site, paying particular attention to match the elevation and geographic characteristics of the two sites. Site elevation and upstream geographic characteristics are important in determining a stream's water temperature. A stream that has a significant fraction of its headwaters in the High Cascades, for example, is likely to be cooler in mid-summer than a stream entirely in the Western Cascades or Coast Range because flow in High Cascade streams typically is driven by snowmelt and high-elevation springs, whereas streams in other geographic areas of the Willamette River basin tend to be rainfall driven (Conlon and others, 2005; Tague and others, 2007). The best water-temperature regressions were obtained when the target site and its correlated site were in the same geographic area and at similar elevations.

Separate regressions typically were constructed to predict a site's daily mean water temperature and its daily temperature range, in order to avoid phase errors that might occur if the hourly or half-hourly data were compared directly. Phase errors in a time series comparison can be caused by subtle timing discrepancies, such as (1) differences in the duration of daylight caused by site location or shading characteristics, or (2) undocumented errors in the time datum (daylight savings time versus standard time). For example, if a site is located far enough west relative to the target site, the timing of sunrise and sundown will occur a fraction of an hour later and delay the daily warming and cooling cycle; direct comparison of water-temperature time series from the two sites would contain a phase error that can be difficult to remove.

Producing separate regressions for the daily mean and the daily range in water temperature is a simple way to circumvent such problems.

Extrapolation of the regression often was necessary to extend incomplete temperature datasets (typically available only for the warmer summer months) to the rest of the year. For some comparisons, a linear regression worked well, but extrapolation of a linear model could result in winter temperature predictions below freezing under some conditions. To remedy that situation, a linear regression could be forced to have a zero intercept, but that might result in a poorer fit to the data in summer. Instead, a more robust regression could be produced for all temperature ranges by fitting a quadratic curve with a zero intercept:

$$
T_{m 1}=a T_{m 2}^{2}+b T_{m 2},
$$

where

$T_{m 1}$ is the daily mean water temperature at the target site (site 1),

$T_{m 2}$ is the measured daily mean water temperature at the correlation site (site 2), and

$a$ and $b$ are regression coefficients. 


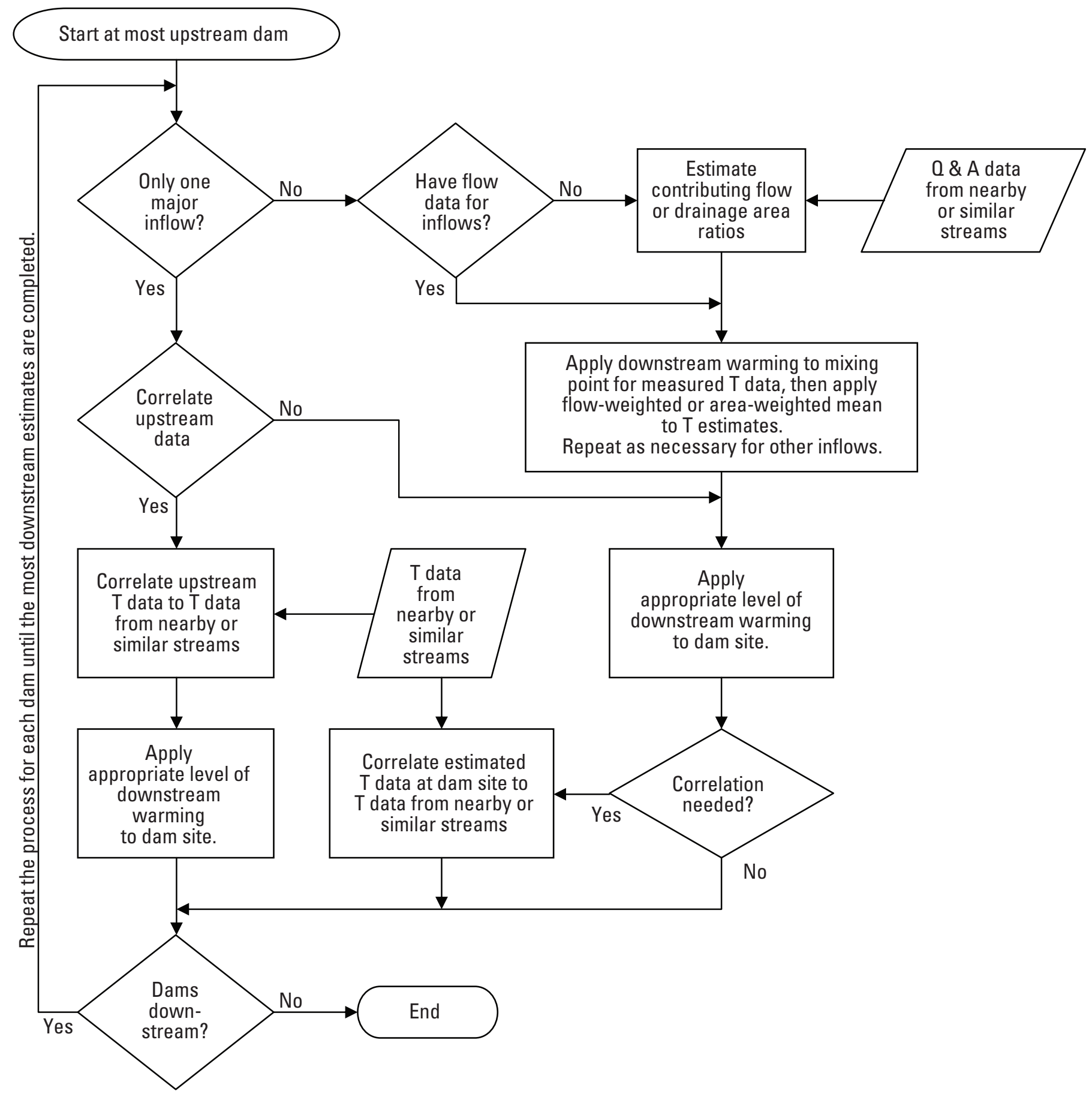

Figure 4. Flow chart showing process for estimating without-dam water temperatures at dam sites in the Willamette River basin, Oregon. [Abbreviations: T, water temperature; 0 , streamflow; $A$, upstream drainage area] 
When this approach was necessary, the coefficient for the quadratic term in the equation typically was small, indicating that only a slight curvature was needed to force the regression curve through zero. Similar approaches were used to correlate the daily range in water temperature at pairs of sites.

When separate daily mean and daily range regressions were used, they were combined to produce a time series of estimated water temperatures by assuming that the timing of any daily variation in temperature at site 1 was similar to that at site 2 . The combined equation, allowing for a quadratic or linear regression of the daily means and a linear regression of the daily ranges, would take the following general form:

$$
T_{1}=a T_{m 2}^{2}+b T_{m 2}+c+\left(T_{2}-T_{m 2}\right)\left(d T_{r 2}+e\right) / T_{r 2},
$$

where

$T_{1}$ is the estimated water temperature at site 1 ,

$T_{m 2}$ is the daily mean water temperature at site 2 ,

$T_{2}$ is the measured hourly or half-hourly water temperature at site 2 ,

$T_{r 2}$ is the daily range in water temperature at site 2 , and

$a-e$ are regression coefficients.

The first three terms are from the daily mean regression, whereas the other terms are used to superimpose a scaled level of daily variation on top of the estimated daily mean. This equation illustrates a typical approach, but the method varied depending on the site.

\section{Mass and Energy Balances}

At the confluence of two streams, both mass and energy are preserved in the mixed waterbody downstream. When the flow in both streams is known, it is trivial to compute the temperature downstream of the confluence by applying an energy balance:

$$
T_{d}=\left(T_{1} Q_{1}+T_{2} Q_{2}\right) /\left(Q_{1}+Q_{2}\right),
$$

where

$T_{d}$ is the downstream temperature,

$T_{1}$ and $T_{2}$ are the temperatures of the two streams upstream of the confluence, and,

$Q_{1}$ and $Q_{2}$ are the flows in those streams.

If flow data are not available, the upstream drainage areas of each stream can be substituted for the flow data as an approximation. This energy balance technique is required for the estimation of without-dam water temperatures when more than one major stream enters the reservoir of interest or if one or more inflows have measurement stations upstream of tributary junctions. Application of the energy balance is best done at each of the relevant stream confluences that would occur in the absence of the reservoir.

\section{Downstream Warming}

During periods of strong solar heating, particularly in summer, water temperatures upstream of a reservoir generally are cooler than the without-dam temperatures that would occur at the downstream dam site. Some amount of warming is likely to occur as the water travels downstream. Several methods could be used to estimate the amount of warming that would result, including (1) estimates based on trends in historical data, (2) measurements of warming in nearby or similar streams, and (3) application of a model that simulates the heat budget of the stream or a similar or idealized stream.

Temperature models of the rivers upstream of and within the reaches now occupied by Willamette River basin reservoirs do not currently exist. Until such models are constructed, which is beyond the scope of this study, any downstream warming must be estimated. CE-QUAL-W2 models are available for the major rivers downstream of most of the dams of interest (see section, "Flow and Temperature Models"). Those models could be used to assess the general magnitude of warming that occurs during summer months just downstream of the dams, provided that the upstream flow and temperature boundary conditions imposed on those models are representative of a no-dams scenario. When that type of no-dam scenario was run for the SF McKenzie River, the simulated warming trend in the daily mean water temperature for the $4 \mathrm{mi}$ downstream of the Cougar dam site was $0.14{ }^{\circ} \mathrm{C} / \mathrm{mi}$ (range: $-0.03-0.28^{\circ} \mathrm{C} / \mathrm{mi}$ ) for June through September. For the North Santiam River, the simulated warming trend in the first $4 \mathrm{mi}$ downstream of the Big Cliff dam site was $0.08^{\circ} \mathrm{C} / \mathrm{mi}$ (range: $0.00-0.16^{\circ} \mathrm{C} / \mathrm{mi}$ ) for the same time period. These rivers, however, may have different characteristics (width, shading) downstream of the dam sites compared to reaches upstream; therefore, these downstream warming trends are only approximate.

Downstream warming rates also can be derived from historical data. Water-temperature data collected from 381 stream sites in Oregon were compiled and documented by Moore (1964) for 1947-62, which spans the period when about half of the major dams were built in the Willamette River basin (table 1). Included in those datasets were pairs of sites on unregulated streams that could be used to assess the magnitude of warming or cooling that occurs as water travels downstream. Results typically showed warming in the downstream direction, with periodic cooling trends during winter. In the warmest summer months, downstream warming could be as much as $0.56{ }^{\circ} \mathrm{C} / \mathrm{mi}\left(1^{\circ} \mathrm{F} / \mathrm{mi}\right.$ in 
the original data units), but normally was much less. An analysis of the data by Moore (1967) indicated that a summertime average downstream warming trend was closer to $0.11^{\circ} \mathrm{C} / \mathrm{mi}\left(0.2^{\circ} \mathrm{F} / \mathrm{mi}\right)$. Indeed, a downstream gradient of exactly $0.11^{\circ} \mathrm{C} / \mathrm{mi}$ was measured in the Middle Fork (MF) Willamette River for July-September 1951-53, just prior to the completion of Lookout Point Dam and within the river reach now occupied by Lookout Point Lake (Moore, 1967). These measured downstream warming rates are almost identical to those that were simulated in the 4 mi downstream of the Cougar and Big Cliff dam sites for a no-dams scenario. Therefore, a summertime maximum downstream warming rate of $0.11{ }^{\circ} \mathrm{C} / \mathrm{mi}$ was used in this study for estimating without-dam temperatures at the dam sites.

The amount of downstream warming varies seasonally, with more warming during summer and proportionally less in spring and autumn. Downstream warming in this study was applied as a maximum of $0.1{ }^{\circ} \mathrm{C} / \mathrm{mi}$ during the warmest months and a linearly decreasing rate for time periods when the stream temperature was cooler. No warming was applied outside of the April through October time period. Stream temperature is a strong function of flow and meteorological conditions and therefore is a good indicator of time periods when the stream is warming. Downstream warming, therefore, was applied only if the stream's upstream temperature exceeded some lower threshold, with the rate linearly increasing until an upper threshold was reached, above which the maximum warming rate was applied. For most of the rivers in this study, subjective lower and upper thresholds of 10 and $16{ }^{\circ} \mathrm{C}$ were used. For rivers with a substantial drainage area in the High Cascades, slightly lower thresholds $\left(6\right.$ and $14{ }^{\circ} \mathrm{C}$ for the North Santiam River; 6 and $12{ }^{\circ} \mathrm{C}$ for the SF McKenzie River) were applied to account for their colder snowmelt sources. Future studies could refine these thresholds by taking into account the different physiographic areas of the basin and determining how the warming rate of a stream tapers off at high temperatures, but no data were available in this study to support the exploration of these threshold dependencies.

Water-temperature data upstream and downstream of reservoirs can provide additional insights into the seasonal pattern of warming and cooling caused by those reservoirs. Moore (1967) quantified this effect for several of the dams of interest in this study. The warming or cooling effects documented by Moore (1967), however, were reported only as monthly temperature changes to the nearest whole degree Fahrenheit. In the absence of measured upstream temperatures (where previously described regression methods could be applied), these monthly warming or cooling patterns could be used to estimate an upstream temperature from a measured temperature downstream of a dam, followed by application of a downstream warming rate to compute a without-dam temperature at the dam site. This method is subject to larger errors than the regression methods used in this study, primarily because observed monthly reservoir warming or cooling patterns neglect shorter-term variations and may differ somewhat from year to year because of variability in dam operations. This approach had to be used for Fern Ridge Dam on the Long Tom River.

\section{Flow and Temperature Models}

The flow and temperature effects of Willamette River basin dams downstream of the USACE and PGE dams was simulated by imposing the without-dam flow and temperature estimates as upstream boundary conditions to the Willamette River TMDL models. The suite of Willamette models is composed of nine models that can be linked together by passing the output of upstream models to the input of downstream models. The models simulate the entire Willamette River and its largest tributaries as far upstream as the first major dam on each tributary (fig. 1). The nine river models include the following reaches:

- Lower Willamette River, with part of the Columbia River as a downstream boundary condition.

- Middle Willamette River, from river mile (RM) 26.5 (Willamette Falls) to RM 85.5 upstream of Salem.

- Upper Willamette River, as far upstream as the confluence of the Coast Fork and Middle Fork Willamette Rivers.

- Clackamas River, the lower 26 mi downstream of River Mill Dam.

- Santiam and North Santiam Rivers, downstream of Big Cliff Dam.

- South Santiam River, downstream of Foster Dam.

- Long Tom River, downstream of Fern Ridge Dam.

- McKenzie River, as far upstream as its confluence with the SF McKenzie River, plus the SF McKenzie River downstream of Cougar Dam.

- Coast Fork and Middle Fork Willamette Rivers, downstream of Cottage Grove Dam on the Coast Fork Willamette River and Dexter Dam on the Middle Fork Willamette River, including the Row River downstream of Dorena Dam and Fall Creek downstream of Fall Creek Dam. 
All nine river models were constructed using CE-QUAL-W2, a state-of-the-art two-dimensional, laterally averaged flow and water-quality model from USACE that is jointly maintained by Portland State University (PSU) (Cole and Wells, 2002). Most of the models were constructed, calibrated, and tested by Dr. Scott Wells' research team at PSU (Annear and others, 2004a, 2004b; Berger and others, 2004). The South Santiam River model was constructed by ODEQ with assistance from the PSU team. The Santiam and North Santiam River model was built, calibrated, and tested by USGS (Sullivan and Rounds, 2004).

These flow and temperature models were calibrated and used to simulate periods during 2 years when data were available for model calibration; June 1-October 31, 2001, and April 1-October 31, 2002. Flow conditions were relatively typical in the summer of 2002, whereas 2001 was a drought year with some reservoirs that did not fill and streamflows at many locations that fell below the lowest 7-day average streamflow that would be expected to occur once in 10 years $\left(7 Q_{10}\right)$. Modeled water temperatures were in good agreement with measured data; mean absolute errors generally were less than $1.0^{\circ} \mathrm{C}$. Much more information about CE-QUAL-W2, its application to these river reaches, and its use in the TMDL is available from Annear and others (2004a, 2004b), Berger and others (2004), and Sullivan and Rounds (2004).

In an attempt to simulate water temperatures that would occur if certain anthropogenic influences were minimized or eliminated, the Willamette River temperature TMDL included a reference condition called Natural Thermal Potential (NTP). Under this NTP condition, point sources were removed, riparian vegetation was restored with some level of natural disturbance, and several instream hydropower projects at Willamette Falls and along the McKenzie River were eliminated (Oregon Department of Environmental Quality, 2006b). Upstream dams and instream withdrawals, however, remained in the NTP model scenario.

The models used in this study were based on the NTP scenario used in the TMDL, but included several small modifications to correct errors, remove instabilities, and make the models more usable. Some of these model changes were documented by Rounds (2007) in a study that used the TMDL models to assess the thermal effects of point sources, riparian shading, and dam operations. During this study, additional modifications were required to run the models under the no-dam flow conditions. For example, large withdrawals for agricultural and municipal use along the South Santiam River downstream of Foster Dam can amount to more flow than is present under no-dam conditions. The largest withdrawal in that reach, the Lebanon-Santiam Canal (USGS station 14187600), by itself averaged more than $100 \mathrm{ft}^{3} / \mathrm{s}$ during mid-summer in 2001 and 2002. As part of the no-dam scenario, withdrawals from the South Santiam River had to be decreased to keep the model stable and prevent the river from becoming dry. Other modifications also were made to the calibrated water-balance flows in the Middle Fork and Coast Fork Willamette River model, and a small error in the distributed tributary temperatures for several branches of the Upper Willamette River model was corrected. The details of these corrections are discussed in section, "Downstream Effects of Willamette Basin Dams."

\section{Data Sources}

Without-dam streamflows and water temperatures were estimated using data from USGS, ODEQ, and USACE. USGS streamflow and water-temperature data were obtained from measurements stored in the USGS National Water Information System database, parts of which can be accessed online (U.S. Geological Survey, 2010a). Daily mean data and other daily statistics are available from http://waterdata.usgs.gov/or/ nwis/sw/ (U.S. Geological Survey, 2010b), and subdaily data from some sites can be accessed at http://or.water.usgs.gov/ grapher/ (U.S. Geological Survey, 2009). USGS streamflow and temperature data not available online are available upon request. USGS protocols and quality assurance procedures for the collection of streamflow and water temperature have been published by Rantz and others (1982) and Wagner and others (2006), respectively; water-temperature measurements typically are accurate to within $0.2^{\circ} \mathrm{C}$. Upstream drainage areas, when needed as a surrogate for streamflow data, were obtained from the USGS Streamstats program, accessible online at http://water.usgs.gov/osw/streamstats/oregon.html (U.S. Geological Survey, 2007).

In addition to the USGS data, water-temperature data from many sites were obtained from ODEQ's LASAR database (Oregon Department of Environmental Quality, 2007) at http://deq12.deq.state.or.us/lasar2/. ODEQ has detailed protocols for the collection and quality assurance of water-temperature data (Oregon Department of Environmental Quality, 2009a). Data from the LASAR database were used in this study only if those data passed the quality assurance checks imposed by ODEQ. USACE data of various types (streamflow, reservoir releases, evaporation rates, etc.) were obtained either directly from USACE staff in the Portland District, or online through the USACE Dataquery tool (U.S. Army Corps of Engineers, no date) at http://www.nwd-wc. usace.army.mil/perl/dataquery.pl. 


\section{Thermal Effects of Dams in the Willamette River Basin}

\section{Without-Dam Flow Estimates at Dam Sites}

Estimates of without-dam streamflow at 11 of the USACE dam sites were constructed from measured dam releases, estimated changes in storage as a function of reservoir stage measurements, and a correction for evaporative losses from the reservoirs. Net inflow estimates based on measured releases and storage changes were obtained from USACE. Measured evaporation rates and known reservoir surface areas were used to correct the net inflows to produce a gross inflow estimate. It was assumed that the flow-regulating dams (Big Cliff and Dexter) had little effect on the net inflow estimates from the much larger dams directly upstream (Detroit and Lookout Point, respectively).

Without-dam streamflows for the Clackamas River at the River Mill dam site were estimated from models and regressions. Simulated no-project flows at the River Mill site were obtained from ODEQ for 2001 through the end of September (Oregon Department of Environmental Quality, 2006b). After that date, and for 2002, the estimated without-dam streamflows were determined through a regression of the available 2001 no-project flows against estimated without-dam flows at the Big Cliff dam site on the North Santiam River. That regression was:

$$
Q_{R M}=1.2733 Q_{N S}-177.5, R=0.972
$$

where

$Q_{R M}$ is the estimated without-dam streamflow in the Clackamas River at the River Mill dam site, in cubic feet per second,

$Q_{N S}$ is the estimated without-dam streamflow in the North Santiam River at the Big Cliff dam site, in cubic feet per second, and

$R$ is the correlation coefficient.

A comparison of with- and without-dam streamflows at most of the dam sites reveals the effects of operating these dams for wintertime flood control and summertime flow augmentation. Dams on the MF Willamette River, for example, stored peak inflows for later release, resulting in lower peak flows in winter $\left(9,970\right.$ versus $\left.21,700 \mathrm{ft}^{3} / \mathrm{s}\right)$ and higher minimum flows in summer (approximately 1,020 versus $633 \mathrm{ft}^{3} / \mathrm{s}$ ) at the Dexter dam site during 2001-02 than might have occurred otherwise (fig. 5, table 3). Dam operation also typically results in streamflows that are relatively constant over periods of weeks, and that change abruptly when gates or spillways are opened to augment flows or make room for additional flood storage, or closed to fill the reservoir or protect downstream areas from flooding.

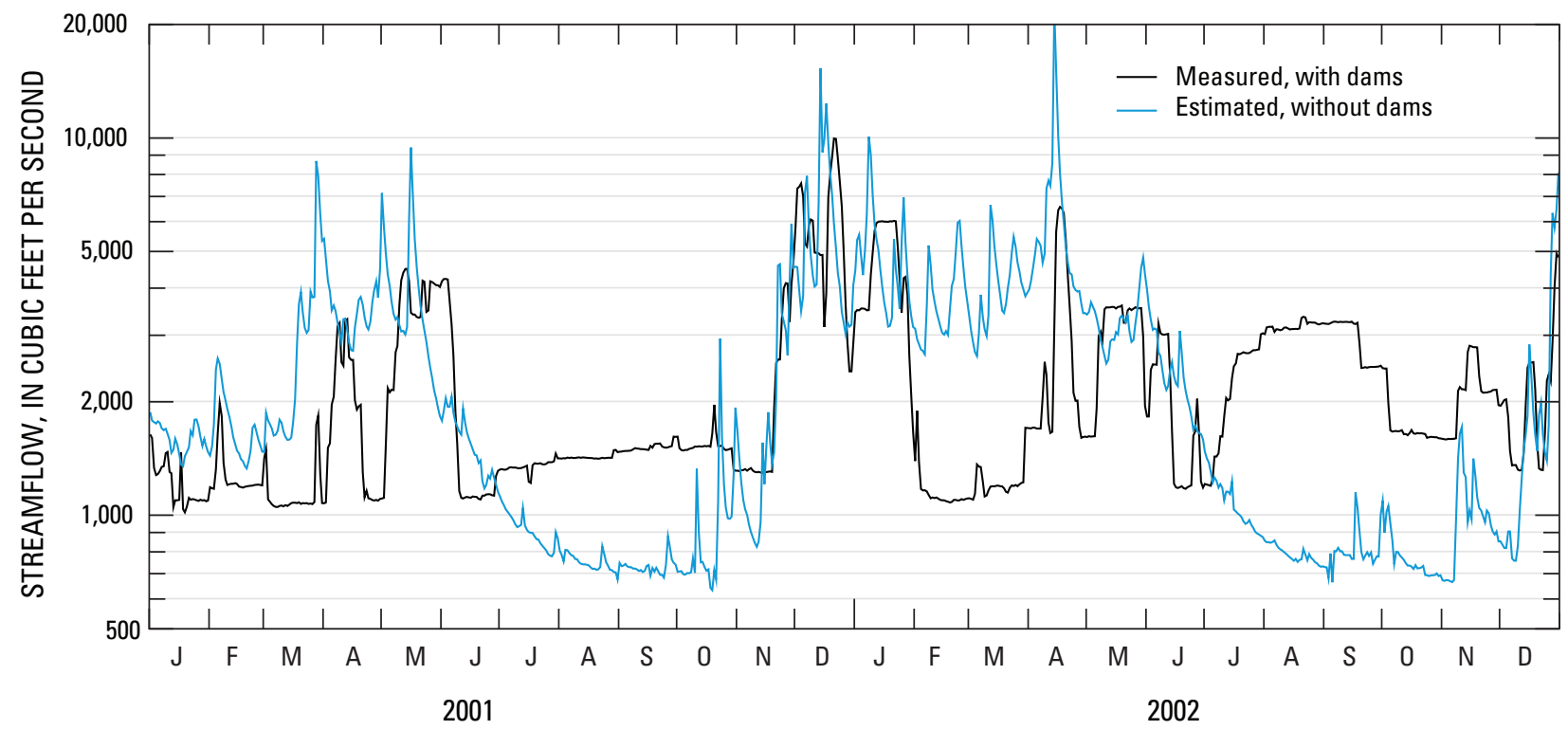

Figure 5. Measured and estimated streamflow for conditions with and without upstream dams in the Middle Fork Willamette River at Dexter Dam, just downstream of Lookout Point Dam in the Willamette River basin, Oregon, 2001-02. Measured flow data are from USGS streamflow-gaging station 14150000. 


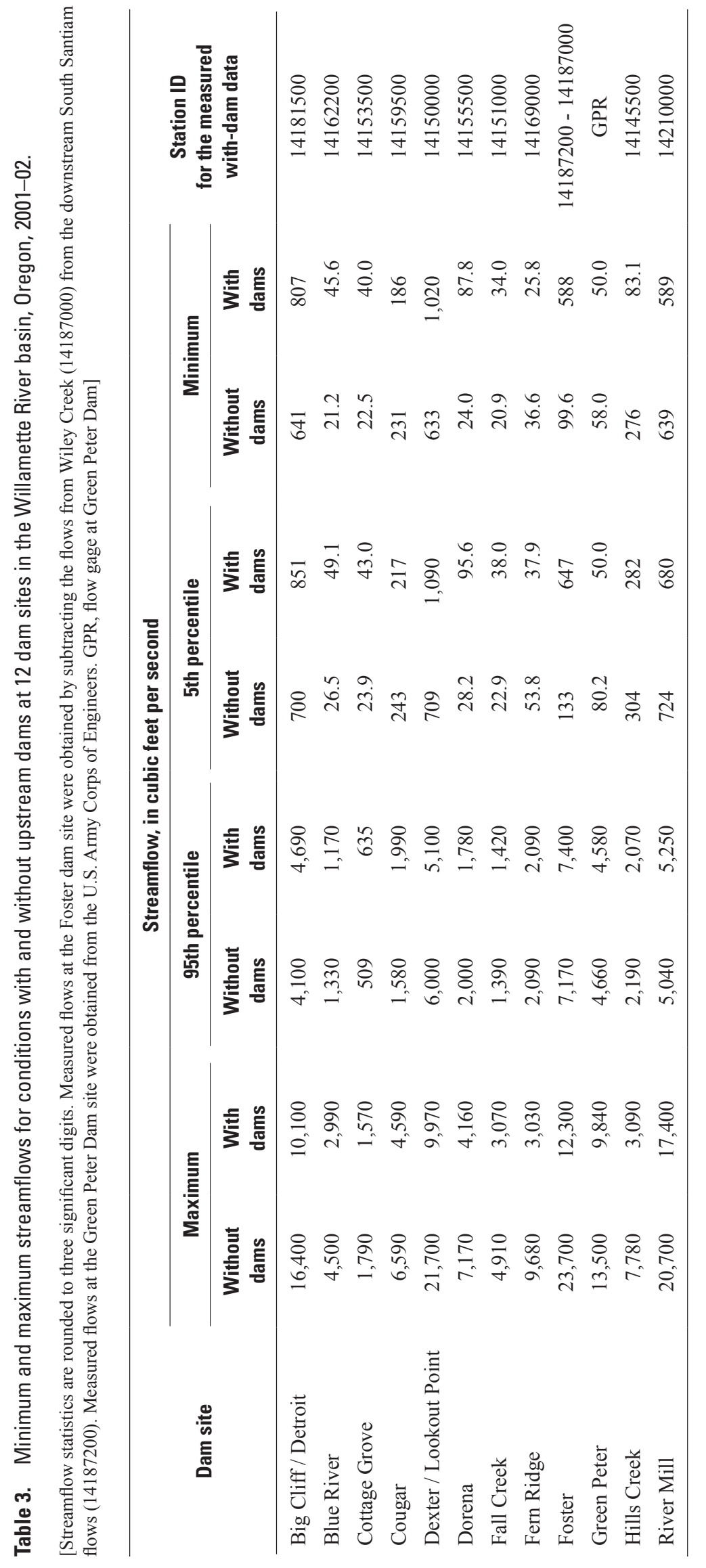


In contrast, streamflow responds quickly to rainfall and snowmelt without the dams, and has a characteristic exponential transition from high-flow to low-flow conditions in the spring to summertime period. Dam operations likely will change in the future, however, as flow variations and higher peak flows increasingly are recognized as important to downstream fish populations and the health of off-channel, wetland, and floodplain ecosystems (Gregory and others, 2007).

The with- and without-dam streamflow comparison shows important differences between the 2001 drought conditions and the more-normal 2002 hydrologic conditions. The winter of 2000-01 was uncharacteristically dry, with insufficient precipitation to allow most of the key storage reservoirs to fill, including Detroit, Green Peter, Blue River, Cougar, Lookout Point, and Hills Creek Lakes. As a result, summertime releases in 2001 were less than those in 2002. Summertime releases from Dexter Dam (and Lookout Point Dam just upstream) on the MF Willamette River in 2001 were roughly one-half of mid-summer releases in 2002. The decreased storage in these dams in 2001 resulted in Willamette River flows that were at or near post-dam $7 Q_{10}$ levels during summer. Because 2001 was a drought year and 2002 was a more typical year, the without-dam temperature estimates from this study reflect a range of hydrologic conditions, which is useful for showing a range of thermal responses.

The with- and without-dam streamflow patterns for two of the shorter dams included in this study, River Mill Dam on the Clackamas River and Fern Ridge Dam on the Long Tom River, show less difference than the streamflow patterns for the larger storage dams. River Mill Dam in particular is more of a run-of-the-river dam. Storage capacities of River Mill Dam and the other upstream dams on the Clackamas River are minimal, which results in without-dam flow estimates that are quite similar to measured flows with the dams in place. The storage capacity of Fern Ridge Dam is substantial despite its relatively short height (table 1); the dam is operated to provide a flood-protection benefit, but its summertime releases for downstream irrigators provides less of a contrast in seasonal flow compared to the with- and without-dam streamflows for some of the larger dams.

Measured with-dam and estimated without-dam streamflows for all dam sites included in this study are graphed in appendix A for 2001-02. Those comparisons illustrate the same general patterns and trends discussed above, but two items discernible in those data merit additional discussion. First, the similarity of with- and without-dam flows at the Cougar dam site during 2002 is a result of the reservoir being drawn down for the construction of a selective withdrawal tower. The reservoir did not fill in 2001, but was drawn down for construction from 2002 through 2004. Second, the estimated without-dam streamflow in the South Santiam River at the Foster dam site decreased during summer to as low as $140 \mathrm{ft}^{3} / \mathrm{s}$ in 2001 and $100 \mathrm{ft}^{3} / \mathrm{s}$ in 2002 . The autumn rains arrived earlier in 2001 than in 2002, or the low-flow minimum in 2001 might have been comparable to that in 2002. Withdrawals from the South Santiam River downstream of Foster Dam can easily exceed the low-flow levels without the dams, especially the diversion through the Lebanon-Santiam Canal, which provides municipal water to the city of Albany and was measured at approximately $90-100 \mathrm{ft}^{3} / \mathrm{s}$ during the summers of 2001-02. Clearly, that level of surface-water diversion could not be supported without the storage provided by upstream dams.

\section{Without-Dam Temperature Estimates at Dam Sites}

Without-dam water temperatures were estimated at the dam sites using a combination of several different methods, following the general process shown in figure 4 . When water-temperature data were available upstream of the reservoirs at each of the major inflows, those temperatures were combined using flow- or drainage-area-weighting techniques and adjusted to account for warming that typically would occur as that water moved downstream to the dam site during summer. Measured temperatures upstream of the reservoirs, however, usually were not available for the entire 2001-02 time period. As a result, regressions between the measured or adjusted temperatures and those from nearby or similar sites were needed to extend the estimates to the entire calendar years of 2001 and 2002. In the sections that follow, the methods used to estimate without-dam water temperatures at each of the dam sites are discussed along with the results. The order of presentation is alphabetical, as listed in table 1. These estimation methods are neither definitive nor unique, but are meant to illustrate the type of estimation method that could be applied, and to emphasize the importance of several types of data sources that are critical to this type of analysis. 


\section{Big Cliff and Detroit Dams}

Big Cliff and Detroit Dams are located on the North Santiam River, which is one of the major Willamette River tributaries draining the Cascade Range (ig. 1). Big Cliff Dam is a relatively small re-regulating dam that smoothes the flow releases from Detroit Dam, which impounds one of the largest storage reservoirs in the Willamette River basin (table 1). The Big Cliff/Detroit dam complex generates more hydropower than any of the other dams in this study. Summertime releases from Detroit Dam during 2001-02 primarily were through its power penstocks, and at a depth that was below the thermocline in mid-summer; therefore, releases at that time were relatively cold. The downstream temperature effects of these dams have been documented previously (Moore, 1967; Laenen and Hansen, 1985; Sullivan and Rounds, 2004; Sullivan and others, 2007).

Upstream of Detroit Lake, the three major inflows (North Santiam River, Breitenbush River, and Blowout Creek) are all gaged; streamflow and water-temperature data are available for the entire 2001-02 time period. As a result, it was relatively simple to compute a flow-weighted mean temperature for the major inflows, and adjust for the warming that probably would have occurred in the $11.8 \mathrm{mi}$ from the head of Detroit Lake to the Big Cliff dam site. The resulting without-dam temperatures at the Big Cliff dam site are plotted in figure $6 \mathrm{~A}$ along with measured temperatures just downstream of Big Cliff Dam at USGS station 14181500. The comparison shows a characteristic shift of the annual maximum water temperature from July or August without dams to September or October. Such a shift is typical downstream of a large storage reservoir that has a mid-level or deeper release point. Releases from Detroit Dam are primarily from the power penstocks, which are below the lake's thermocline in mid-summer, resulting in relatively cold downstream temperatures in July and August. The process of drawing down the lake in September to make room for flood storage, however, brings warmer surface waters down to the power penstocks, resulting in warmer downstream temperatures in September and October.

The comparison of with- and without-dam water temperatures clearly shows that the dams have both a cooling and a warming effect. During mid-summer, Big Cliff and
Detroit Dams release water that is as much as $8^{\circ} \mathrm{C}$ cooler than might occur without the dams, whereas releases in September or October can be $6-8{ }^{\circ} \mathrm{C}$ warmer than without the dams. Because the releases from Detroit Dam are from deep within the lake, little daily variation in water temperature occurs with the dams in place, compared to a daily range of about $4{ }^{\circ} \mathrm{C}$ without the dams in mid-summer.

Oregon's maximum water-temperature standard specifies a 7dADM water temperature for comparison to numeric criteria (Oregon Department of Environmental Quality, 2009b). Without the dams, the maximum water temperature at the Big Cliff dam site is relatively consistent from 2001 to 2002 , with a $7 \mathrm{dADM}$ temperature between 17 and $18{ }^{\circ} \mathrm{C}$ in late July or early August (table 4). The maximum without-dam 7 dADM temperature was slightly higher in 2001 than in 2002, a difference that probably is due to lower streamflow during the 2001 drought conditions. With the dams, the maximum measured 7dADM temperature was as low as $13.7^{\circ} \mathrm{C}$ in 2002 . Because the lake did not fill in 2001, the warmer surface water was closer to the power penstock intake level, resulting in a higher maximum release temperature.

Comparing these temperatures as cumulative frequency curves, it is clear that the without-dam dataset contains both cooler and warmer temperatures (fig. 7). For example, temperatures were estimated to be cooler than $8{ }^{\circ} \mathrm{C}$ during 2001-02 about 59 percent of the time without dams, but only about 50 percent of the time with dams. The distribution is more similar in the $11-15{ }^{\circ} \mathrm{C}$ range, above which the curves diverge, where the without-dam temperatures increase to a maximum that is $1.6^{\circ} \mathrm{C}$ higher than the with-dam maximum. The shape of the with-dam curve, of course, is greatly affected by dam operations and the fact that Detroit Lake did not completely fill in 2001. More important than the distribution of annual temperatures, however, is the shift of the annual maximum from mid-summer without dams to early autumn with dams because of the effect of that seasonal pattern on the timing of fish migration and spawning. The seasonal pattern in water temperature is of critical importance to the life cycle and survival of anadromous fish, and the temperature of water released by dams is an important controlling factor affecting that seasonal pattern (Caissie, 2006). 


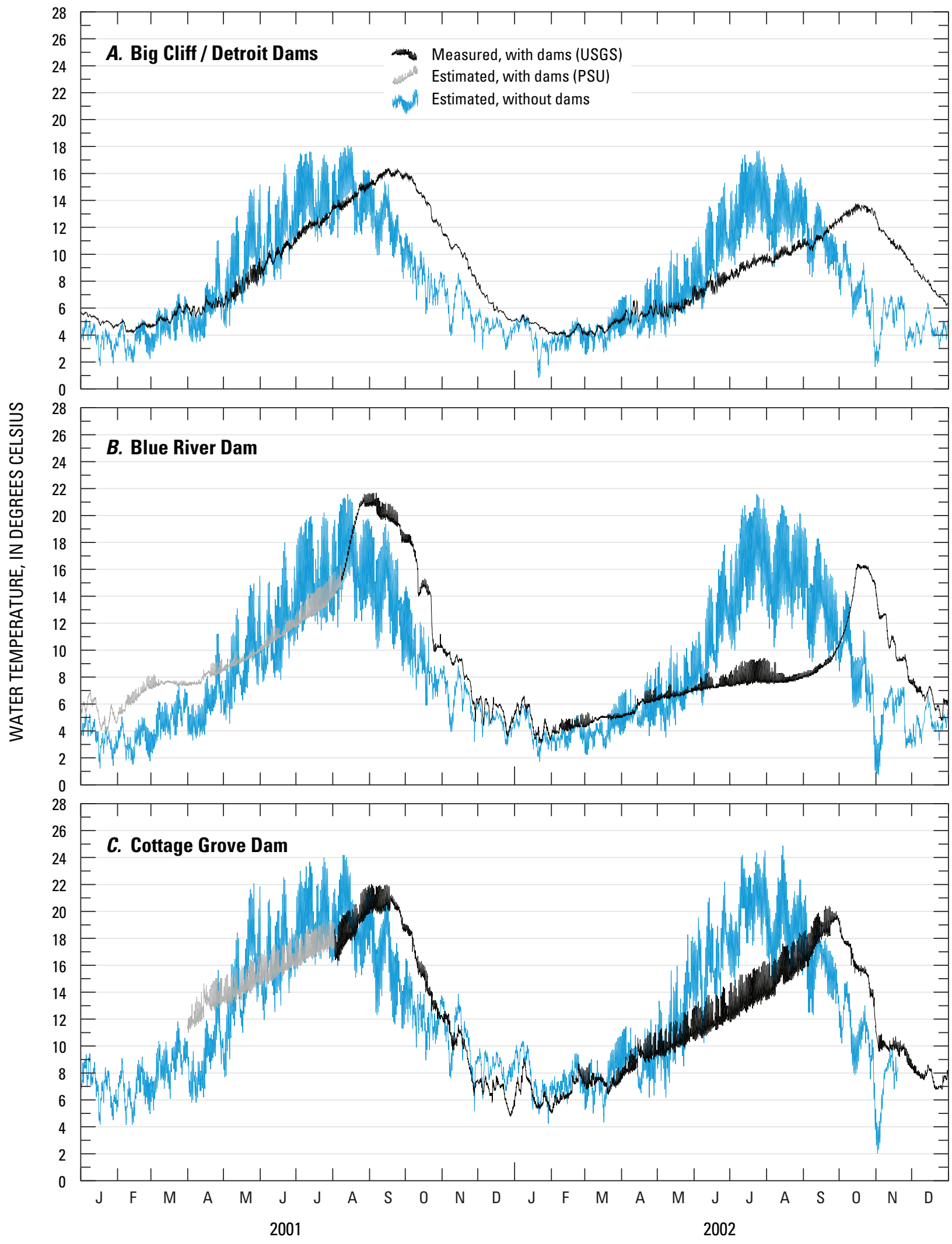

Figure 6. Measured and estimated water temperatures for conditions with and without upstream dams at the Big Cliff / Detroit, Blue River, and Cottage Grove dam sites in the Willamette River basin, Oregon, 2001-02. Estimated with-dam temperatures are from Annear and others (2004a) at Portland State University (PSU). Measured temperatures are from USGS stations 14181500,14162200 , and 14153500 for graphs $A, B$, and $C$, respectively. 
Table 4. Measured with-dam and estimated without-dam annual maximum water temperatures as measured by the 7-day average of the daily maximum at selected dam sites in the Willamette River basin, Oregon, 2001-02.

[7dADM, 7-day running average of the daily maximum; na, not available; *, estimate because dataset is incomplete]

\begin{tabular}{|c|c|c|c|c|c|}
\hline \multirow{3}{*}{ Dam site } & \multicolumn{4}{|c|}{ Annual maximum 7dADM, in degrees Celsius (month/day of maximum 7dADM) } & \multirow{3}{*}{$\begin{array}{l}\text { USGS station ID } \\
\text { for the measured } \\
\text { with-dam data }\end{array}$} \\
\hline & \multicolumn{2}{|c|}{2001} & \multicolumn{2}{|c|}{2002} & \\
\hline & Without dams & With dams & Without dams & With dams & \\
\hline Big Cliff / Detroit & $17.9(8 / 13)$ & $16.3(9 / 15)$ & $17.2(7 / 23)$ & $13.7(10 / 17)$ & 14181500 \\
\hline Blue River & $21.1(8 / 12)$ & $21.6(9 / 01)$ & $21.0(7 / 26)$ & $16.3(10 / 19)$ & 14162200 \\
\hline Cottage Grove & $23.6(8 / 12)$ & $21.9(9 / 12)$ & $23.4(7 / 27)$ & $20.2(9 / 21)$ & 14153500 \\
\hline Cougar & $15.2(7 / 06)$ & $14.5(10 / 02)$ & $15.3(7 / 12)$ & $17.4(7 / 29)$ & 14159500 \\
\hline Dexter / Lookout Point & $23.2(8 / 10)$ & $20.4(9 / 15)$ & $23.6(7 / 23)$ & $18.8(9 / 22)$ & 14150000 \\
\hline Dorena & $25.1(8 / 10)$ & $19.3(9 / 29)$ & $25.8(7 / 27)$ & $18.6(10 / 01)$ & 14155500 \\
\hline Fall Creek & $21.5(8 / 12)$ & $16.6(10 / 17)^{*}$ & $21.6(7 / 23)$ & $21.3(8 / 31)$ & 14151000 \\
\hline Fern Ridge & $23.0(7 / 10)$ & $23.3(8 / 12)^{*}$ & $22.0(7 / 16)$ & $24.1(7 / 24)$ & 14169000 \\
\hline Foster & $24.5(8 / 12)$ & $13.2(8 / 29)$ & $24.5(7 / 22)$ & $13.1(7 / 19)$ & 14187200 \\
\hline Green Peter & $23.4(8 / 12)$ & na & $23.9(7 / 23)$ & na & na \\
\hline Hills Creek & $19.4(8 / 13)$ & na & $19.9(7 / 13)$ & na & na \\
\hline River Mill & $19.0(8 / 10)$ & $17.9(8 / 15)$ & $18.0(7 / 23)$ & $18.5(7 / 27)$ & 14210000 \\
\hline
\end{tabular}

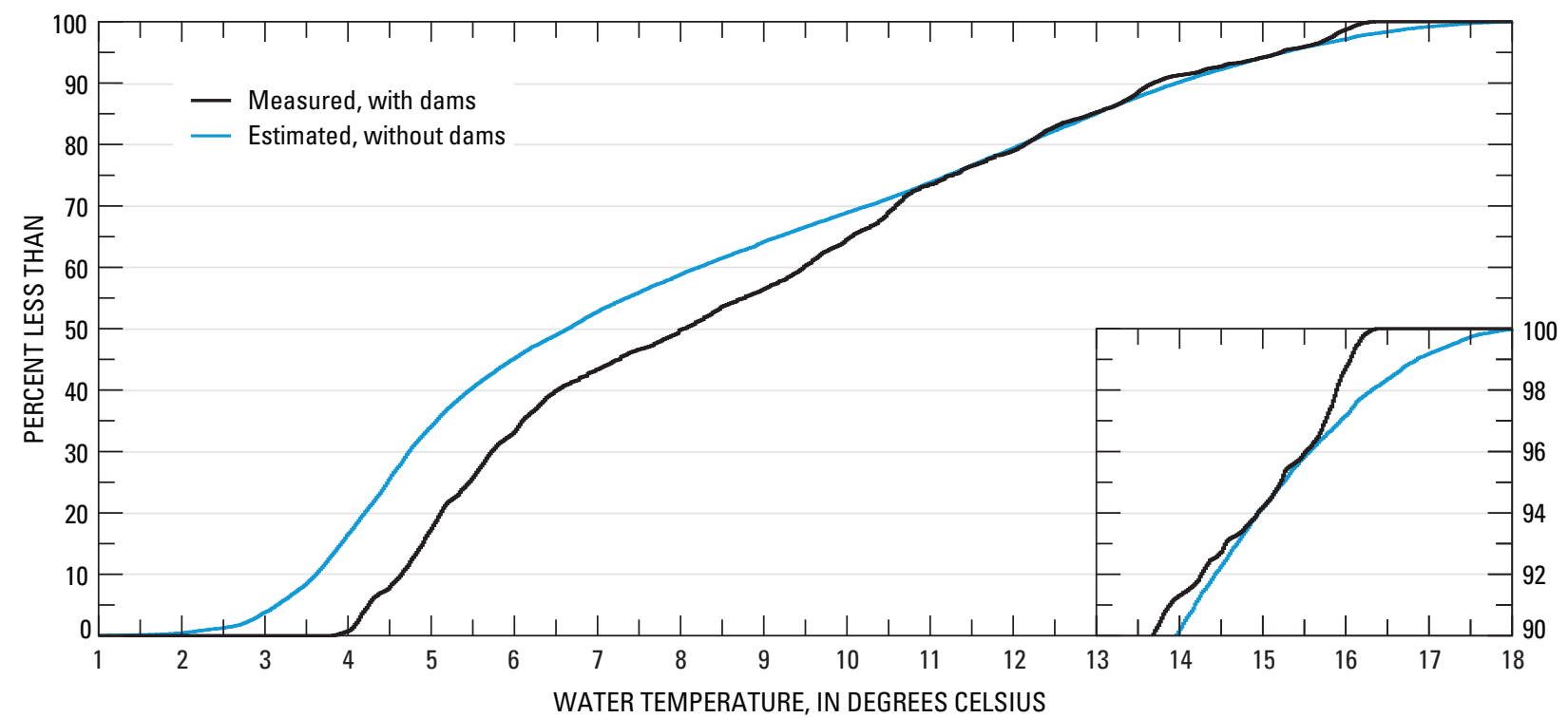

Figure 7. Cumulative frequency curves of measured and estimated water temperatures for conditions with and without upstream dams at the Big Cliff dam site in the Williamette River basin, Oregon, 2001-02. Measured withdam temperatures are from USGS station 14181500 just downstream of Big Cliff Dam. The inset graph shows an expanded vertical scale at the highest temperatures. 
Without-dam temperature estimates are affected by several sources of uncertainty. Because measured flows and temperatures were available for the entire 2001-02 time period upstream of Detroit Lake, the uncertainty derives primarily from the estimated rate of downstream heating for the warmer periods during summer. A model was not available to account for the actual travel time and the degree of topographic shading as the water moved from the head of Detroit Lake to the Big Cliff dam site. Downstream of the dam, however, a model of the North Santiam River was used to determine a downstream warming rate of $0.08{ }^{\circ} \mathrm{C} / \mathrm{mi}$ (range: 0.00 to $0.16^{\circ} \mathrm{C} / \mathrm{mi}$ ), which is close to the assumed maximum warming rate of $0.11^{\circ} \mathrm{C} / \mathrm{mi}$. Applied over a distance of $11.8 \mathrm{mi}$, a warming rate of $0.11^{\circ} \mathrm{C} / \mathrm{mi}$ produces a maximum warming of $1.3^{\circ} \mathrm{C}$. If the warming rate was in error by as much as $0.05^{\circ} \mathrm{C} / \mathrm{mi}$, an uncertainty of as much as $0.6^{\circ} \mathrm{C}$ could result. Combined with measurement errors of $\pm 0.2^{\circ} \mathrm{C}$, the without-dam temperature estimates at the Big Cliff dam site are likely to have an uncertainty of no more than 0.5 to $0.8^{\circ} \mathrm{C}$ (table 5).

Table 5. Maximum estimated error ranges for the without-dam water-temperature estimates at selected dam sites in the Willamette River basin, Oregon.

$\left[{ }^{\circ} \mathrm{C}\right.$, degrees Celsius; na, not applicable $]$

\begin{tabular}{lcccc}
\hline \multicolumn{1}{c}{ Dam site } & $\begin{array}{c}\text { Maximum } \\
\text { measurement } \\
\text { error }\left({ }^{\circ} \mathbf{C}\right)\end{array}$ & $\begin{array}{c}\text { Maximum } \\
\text { regression } \\
\text { error }\left({ }^{\circ} \mathbf{C}\right)\end{array}$ & $\begin{array}{c}\text { Maximum } \\
\text { warming rate } \\
\text { error }\left({ }^{\circ} \mathbf{C}\right)\end{array}$ & $\begin{array}{c}\text { Total maximum } \\
\text { estimated } \\
\text { error }\left({ }^{\circ} \mathbf{C}\right)\end{array}$ \\
\hline Big Cliff / Detroit & 0.2 & na & 0.6 & $0.5-0.8$ \\
Blue River & 0.2 & $0.3-0.6$ & 0.6 & $0.5-1.4$ \\
Cottage Grove & 0.2 & $0.5-1.0$ & 0.3 & $0.5-1.5$ \\
Cougar & 0.2 & na & 0.3 & 0.5 \\
Dexter / Lookout Point & 0.2 & 0.6 & $0.6-1.1$ & $1.5-1.8$ \\
Dorena & 0.2 & 0.5 & 0.3 & $0.5-1.0$ \\
Fall Creek & 0.2 & 0.7 & 0.6 & $0.8-1.5$ \\
Fern Ridge & 0.2 & $0.8-1.2$ & 0.6 & $1.0-2.0$ \\
Foster & 0.2 & 0.6 & 0.8 & $0.8-1.5$ \\
Green Peter & 0.2 & 0.4 & 0.5 & $0.5-1.0$ \\
Hills Creek & 0.2 & 0.5 & 0.4 & $0.5-1.0$ \\
River Mill & 0.2 & 0.6 & na & $11.0-1.6$ \\
\hline
\end{tabular}

${ }^{1}$ Estimated error for River Mill includes an estimate of potential error from the no-project model scenario. 


\section{Blue River Dam}

Blue River Dam is located on Blue River, which is a tributary to the McKenzie River just downstream of the SF McKenzie River confluence (fig. 1). The entire drainage of Blue River is in the Western Cascades physiographic province, which means that its flow is generated more from rainfall than from snowmelt, and it does not benefit from the cold springs and higher baseflow characteristics of High Cascades streams (Tague and others, 2007). The temperature effects of Blue River and Cougar Dams on McKenzie River temperatures has been studied in previous research by Hansen (1988).

Estimation of without-dam water temperatures at the Blue River dam site provides an excellent example of the regression procedure used in this study. No temperature data upstream of Blue River Lake were available for the period of interest in 2001 or 2002, but upstream water temperatures were measured by ODEQ from June 15 through August 23, 2000, at a site 11.6 mi upstream of the dam (site 23910, data from ODEQ's LASAR database, Oregon Department of Environmental Quality, 2007). A correlation to measured water temperatures at a nearby or similar site was needed to estimate water temperatures in Blue River for the 2001-02 time period. A comparison of the available data showed that Blue River temperatures during the summer were not at all similar to those from the SF McKenzie River upstream of Cougar Reservoir, a nearby site with a long dataset; the dissimilarity probably was the result of the SF McKenzie River having its headwaters in the High Cascades whereas Blue River has its headwaters entirely within the Western Cascades. A nearby site on Blowout Creek in the North Santiam River basin only about $30 \mathrm{mi}$ to the north, however, has a continuous temperature record and is similar to the Blue River site in terms of its general elevation, physiographic province, and basin size. A comparison between the temperature data from 2000 for Blue River and Blowout Creek showed a strong similarity.

The available Blue River temperature data from the summer of 2000 were correlated with measured temperatures for the same period from the Blowout Creek site (USGS station 14180300). To avoid phase errors derived from the fact that the two sites probably are affected by different topographic shading characteristics and the timing of local sunrise and sundown, the daily means and daily ranges were correlated separately. The regressions with the best fit are described by the following equations:

$$
\begin{gathered}
T_{m B R}=-0.003843 T_{m B C}^{2}+1.041 T_{m B C}, R=0.986 . \\
T_{r B R}=0.9335 T_{r B C}, R=0.864,
\end{gathered}
$$

where

$T_{m B R}$ is the predicted daily mean temperature for Blue River,

$T_{m B C}$ is the measured daily mean temperature for Blowout Creek,

$T_{r B R}$ is the predicted daily temperature range for Blue River, and

$T_{r B C}$ is the measured daily temperature range for Blowout Creek.

Both regressions provided good fits to the data with correlation coefficients $(R)$ greater than 0.85 ; the correlation of the daily means was particularly good. These equations indicate that the daily temperature range of Blue River is about 93 percent of the daily temperature range of Blowout Creek, and the daily mean temperature of Blue River is about 4 percent larger than the daily mean temperature of Blowout Creek. A small quadratic term was included in the regression of the daily means so that an extrapolation from summer to winter conditions would not cause a bias. Measured water temperatures at these sites are quite similar, and the regressions bear that out. Combining these equations and assuming that the timing in the daily variation of water temperature at Blue River is similar to that at Blowout Creek, the following equation is derived:

$$
\begin{aligned}
T_{B R}= & -0.003843 T_{m B C}^{2}+1.041 T_{m B C} \\
& +0.9335\left(T_{B C}-T_{m B C}\right),
\end{aligned}
$$

where

$T_{B R}$ is the predicted temperature of Blue River, and $T_{B C}$ is the half-hourly temperature of Blowout Creek.

The resulting predicted temperatures are an excellent match for the measured temperatures of Blue River (fig. 8). 

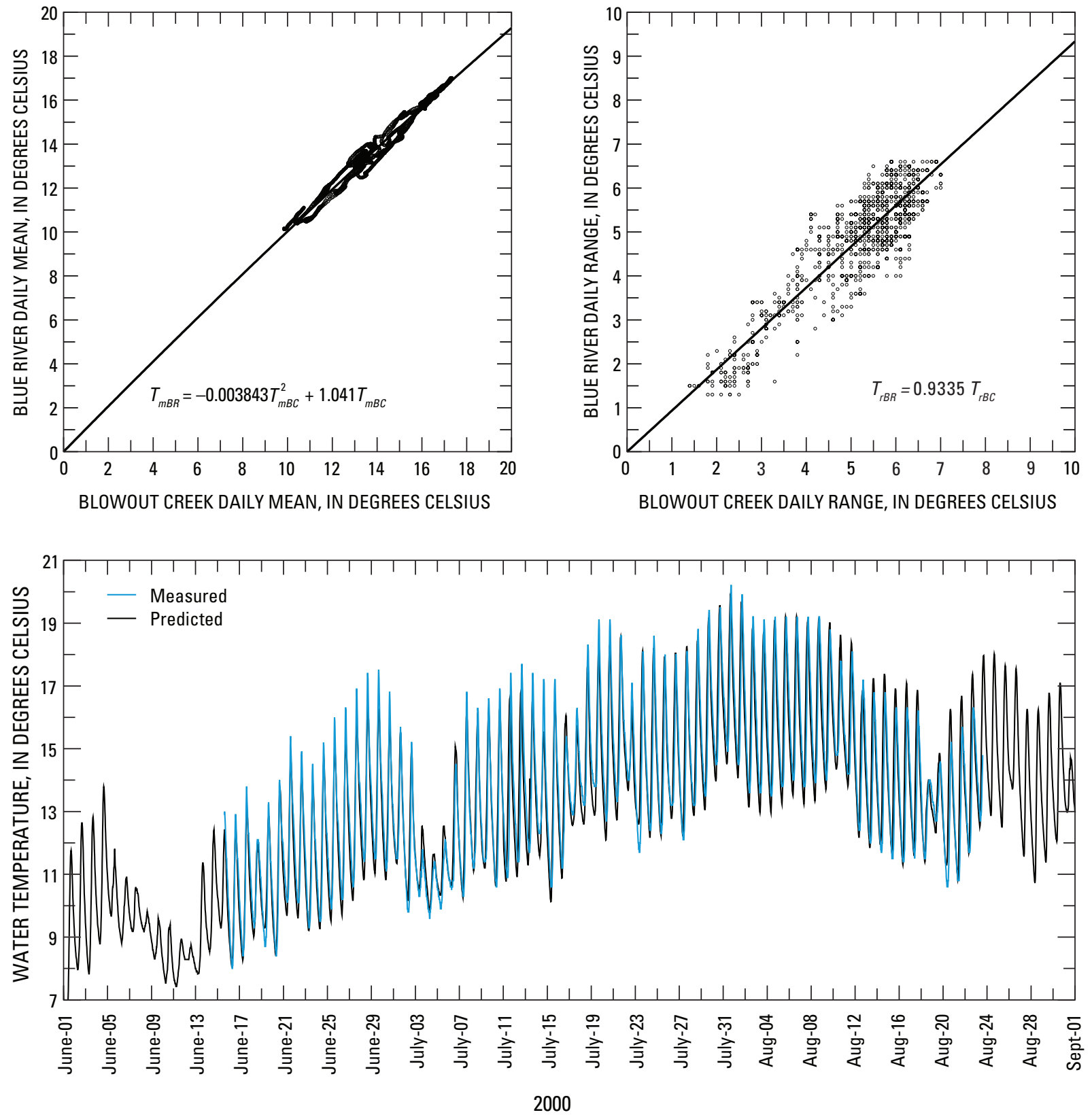

Figure 8. Correlation of water temperatures for Blue River (BR) and Blowout Creek (BC) in the Willamette River basin, Oregon, for a period in mid-summer of 2000 . Daily means and daily ranges in water temperature were correlated separately and then recombined to produce the final prediction. 


\section{Thermal Effects of Dams in the Willamette River Basin, Oregon}

The predicted Blue River temperatures from the regression analysis do not reflect temperatures that would occur 11.6 mi downstream at the Blue River dam site. A maximum downstream warming rate of $0.11^{\circ} \mathrm{C} / \mathrm{mi}$ was assumed (see section, "Methods and Models") and applied for those times in summer when the stream was likely to be warming. The final estimated without-dam water temperatures at the Blue River dam site are plotted in figure $6 \mathrm{~B}$ along with measured water temperatures at that site in 2001-02.

As was the case for temperatures at the Big Cliff dam site on the North Santiam River, without-dam temperatures in Blue River at the dam site are relatively consistent from year to year. An annual maximum 7dADM water temperature was estimated to be about $21^{\circ} \mathrm{C}$ without the dam and would occur in the July to August time period (table 4). With the dam in place, in contrast, the measured annual maximum 7dADM occurred in September or October. Blue River Lake did not fill in 2001, causing warmer releases downstream because the warmer surface layer was closer to the elevation of the lake outlet. In 2002, the lake did fill and releases were cooler throughout the summer and autumn.

The annual maximum temperature estimated for Blue River without Blue River Dam (about $21^{\circ} \mathrm{C}$ ) is warmer than the annual maximum without-dam temperature estimated for the North Santiam River at the Big Cliff dam site $\left(17-18^{\circ} \mathrm{C}\right)$. The difference probably is a result of the upstream drainage characteristics, a theme that recurs throughout this report. The Blue River drainage is entirely within the Western Cascades physiographic province, whereas a large fraction of the North Santiam River upstream of Big Cliff Dam drains from the High Cascades area (fig. 2). Annual maximum temperatures typically are higher for Western Cascade streams than for High Cascade streams because the latter derive a large proportion of their flow from cold springs and groundwater fed from snowmelt, whereas Western Cascade streams lack that consistently cold source of water during the low-flow season.

Uncertainties in the without-dam temperature estimates for Blue River can be attributed to errors in the regressions as well as errors in the estimated rate of downstream warming from the correlation site to the dam site. An analysis of the regression data from the summer of 2000 shows little error in the prediction of the daily mean temperature, with an insignificant mean error (ME, bias) of only $-0.005^{\circ} \mathrm{C}$ and a small mean absolute error (MAE, typical error for any data point) of $0.25^{\circ} \mathrm{C}$. Errors in the predicted daily minimum or maximum temperature are larger, with an MAE of 0.35$0.58{ }^{\circ} \mathrm{C}$ and an $\mathrm{ME}$ of $-0.21{ }^{\circ} \mathrm{C}$. Estimates of measurement error $\left( \pm 0.2^{\circ} \mathrm{C}\right)$, error in the rate of downstream warming $\left(<0.6{ }^{\circ} \mathrm{C}\right)$, and regression prediction errors $\left(0.3-0.6{ }^{\circ} \mathrm{C}\right)$ are difficult to combine, but the overall uncertainty in the summertime temperature estimates for Blue River is likely to be in the range of 0.5 to $1.4^{\circ} \mathrm{C}$ (table 5). 


\section{Cottage Grove Dam}

Cottage Grove Dam is located on the Coast Fork Willamette River just upstream of Cottage Grove, Oregon. The upstream drainage mostly lies within the Western Cascades physiographic area, with a small fraction in the Willamette Lowlands area (fig. 2). Along with Fern Ridge Dam, Cottage Grove Dam was one of the first USACE dams built in the Willamette River basin. Its storage volume is relatively small compared with most of the other USACE reservoirs in the basin.

The best estimates of without-dam temperatures at the dam sites make use of measured temperatures upstream of the reservoirs. Measured temperatures were available from ODEQ for the Coast Fork Willamette River upstream of Cottage Grove Lake at London (LASAR site 28614) for August 2 September 26, 2001, and April 21-September 9, 2002. A maximum downstream heating adjustment of $0.11^{\circ} \mathrm{C} / \mathrm{mi}$ was applied for the $6.5 \mathrm{mi}$ to the dam site, but only for those periods during summer when heating was likely (see section, "Methods and Models").

To estimate without-dam water temperatures for the rest of 2001-02, correlations with data from other sites were required. In 2001, measured water temperatures in Mosby Creek downstream of Row River Trail were available from ODEQ (LASAR site 28103) for June 21-October 3. A correlation between these temperatures from Mosby Creek and the adjusted without-dam temperatures for the Coast Fork Willamette River showed an excellent similarity, with no need to correlate the daily means and daily ranges separately:

$$
T_{C F}=0.9465 T_{M C}+0.4053, R=0.963,
$$

where

$$
\begin{aligned}
& T_{C F} \text { is the estimated without-dam temperature in } \\
& \text { the Coast Fork Willamette River, and } \\
& T_{M C} \text { is the measured temperature in Mosby Creek. }
\end{aligned}
$$

This regression was used for the periods June 21-August 2 and September 26-October 3 in 2001. Prior to June 21 and after October 3 in 2001, a correlation with measured water temperatures in the SF McKenzie River upstream of Cougar Reservoir (USGS station 14159200) provided a good fit, despite the fact that the SF McKenzie River drains water from the High Cascades. A correlation with data from Blowout Creek in the Western Cascades did not fit as well. Separating the daily means from the daily ranges, the following regression was used:

$$
\begin{aligned}
T_{C F}= & 0.014909 T_{m S F}^{2}+1.5081 T_{m S F} \\
& +1.2852\left(T_{S F}-T_{m S F}\right),
\end{aligned}
$$

where the temperatures on the right-hand side of the equation are from the SF McKenzie River site and the $m$ subscript indicates the daily mean. The daily mean and daily range regressions produced correlation coefficients of 0.934 and 0.678 , respectively.

Measured water temperatures were available from June 20 to November 19, 2002, for Mosby Creek at Laying Road (LASAR site 30638), which is a nearby unregulated tributary to the Row River near Cottage Grove. A comparison of these water-temperature data from Mosby Creek with temperatures from the Coast Fork Willamette River upstream of Cottage Grove Lake indicated that the data were similar enough to be used without further adjustment. No downstream heating adjustment was applied because the elevation of the Mosby Creek site is similar to the elevation of Cottage Grove. These data were used to fill out the 2002 without-dam temperature time series after September 9, 2002. A correlation with measured temperatures in the SF McKenzie River upstream of Cougar Reservoir was used for the period prior to April 21, 2002. (As for the 2001 data, a correlation with Blowout Creek temperatures was not as successful.) A new regression was prepared for the 2002 data, and the results were similar to the regression used for 2001:

$$
\begin{aligned}
T_{C F}= & 0.010234 T_{m S F}^{2}+1.6169 T_{m S F} \\
& +1.2458\left(T_{S F}-T_{m S F}\right) .
\end{aligned}
$$

This regression was used to estimate without-dam water temperatures for the Coast Fork Willamette River for January 1-April 21, 2002. Correlation coefficients for the daily mean and daily range regressions were 0.964 and 0.591 , respectively. The 2001 and 2002 datasets could have been combined and a single regression constructed, but the results would not have been different enough to be of concern.

The without-dam water-temperature estimates at the Cottage Grove dam site show a seasonal pattern that is similar to those estimated at other dam sites, with peak annual temperatures occurring in July or August rather than in September with the dam in place (fig. 6C). The annual maximum $7 \mathrm{dADM}$ without-dam temperature is about $23.5^{\circ} \mathrm{C}$, which is warmer than the estimates for the Blue River dam site, despite both sites draining areas in the Western Cascades. That difference is consistent with the lower elevation at Cottage Grove.

Uncertainties in the without-dam temperature estimates at the Cottage Grove dam site vary depending on whether those estimates were derived from upstream measurements, from nearby sites, or from correlations with sites farther away. The downstream warming was applied over only $6.5 \mathrm{mi}$ compared to about $11.5 \mathrm{mi}$ for the previous two dam sites, so the uncertainty in that adjustment might account for an error of $0.3^{\circ} \mathrm{C}$ or less. Errors associated with the regressions are likely to be higher (about $0.5-1.0^{\circ} \mathrm{C}$ ). Overall, these without-dam temperatures probably have uncertainties on the order of 0.5 to $1.5^{\circ} \mathrm{C}$ (table 5). 


\section{Cougar Dam}

Cougar Dam is located on the SF McKenzie River about $4.5 \mathrm{mi}$ upstream of its confluence with the McKenzie River. Built in 1963, Cougar Dam is the second tallest dam in the Willamette River basin and impounds the fifth largest volume of water in Cougar Reservoir. USGS maintains a streamflow-gaging station upstream of Cougar Reservoir (station 14159200) where water temperature also is measured and available for the entire 2001-02 period of interest. The SF McKenzie River is the major inflow to Cougar Reservoir, with minor contributions from Walker Creek and the East Fork of the SF McKenzie River.

Without-dam water temperatures at the Cougar dam site were estimated by applying a reasonable downstream warming rate to the water temperatures measured upstream of Cougar Reservoir at USGS station 14159200. A maximum downstream heating rate of $0.11^{\circ} \mathrm{C} / \mathrm{mi}$ was applied for the $6 \mathrm{mi}$ from the measurement site to the dam site. This maximum heating rate was applied when the upstream measured temperatures exceeded $12{ }^{\circ} \mathrm{C}$. No downstream heating adjustment was applied when upstream temperatures were less than $6{ }^{\circ} \mathrm{C}$, and a linearly interpolated fraction of the maximum rate was applied for upstream temperatures between 6 and $12{ }^{\circ} \mathrm{C}$. These temperature thresholds are lower than those applied at most of the other sites, primarily because summertime temperatures in the SF McKenzie River tend to be colder than those upstream of the other reservoirs. Because the SF McKenzie River derives a substantial fraction of its flow from the High Cascades during summer, it tends to be relatively cool (Tague and others, 2007).
Measured with-dam and estimated without-dam water temperatures at the Cougar dam site show the characteristic shift of annual maximum temperatures caused by dam operations in 2001 but not in 2002 (fig. 9A). Cougar Reservoir did not fill during the drought winter of 2000-01, but releases were still cool in mid-summer because water was released from deep in the lake. In 2002, the lake had been drawn down to allow for the construction of a selective withdrawal tower at the dam. With little water in storage, a more natural seasonal temperature pattern occurred in 2002, but some warming exceeding the without-dam condition occurred as a result of the impoundment, capture of solar radiation, and no ability to release water from a cooler hypolimnion.

Without-dam annual maximum $7 \mathrm{dADM}$ temperatures at the Cougar dam site were estimated to be just over $15^{\circ} \mathrm{C}$, colder than the estimates from any other dam site in this study (table 4). Maximum without-dam temperatures at the Big Cliff dam site are the next coolest, but still warmer by more than $2{ }^{\circ} \mathrm{C}$. Both sites are located at approximately $1,200 \mathrm{ft}$ above sea level and derive much of their flow from the High Cascades, but temperatures in the SF McKenzie River upstream of Cougar Reservoir (USGS station 14159200) are colder in mid-summer by about $2{ }^{\circ} \mathrm{C}$ compared to temperatures in the North Santiam River just upstream of Detroit Lake (USGS station 14178000). Uncertainties in the without-dam water temperatures at the Cougar dam site are derived primarily from errors in the downstream warming rate, which are on the order of $0.3^{\circ} \mathrm{C}$ for this site. Overall, errors in the without-dam temperatures at this site should be less than $0.5^{\circ} \mathrm{C}$ (table 5). 


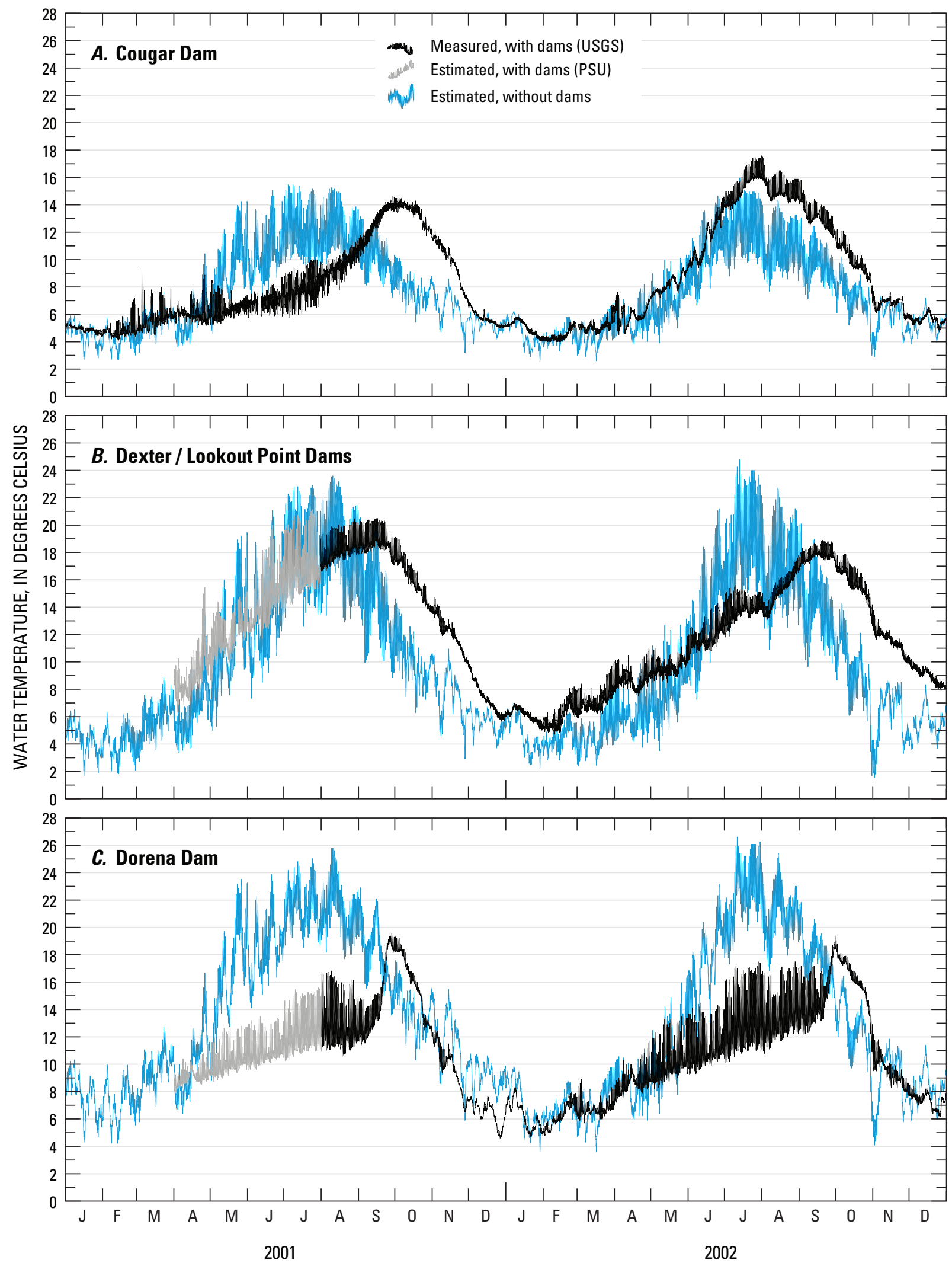

Figure 9. Measured and estimated water temperatures for conditions with and without upstream dams at the Cougar, Dexter / Lookout Point, and Dorena dam sites in the Willamette River basin, Oregon, 2001-02. Estimated with-dam temperatures are from Annear and others (2004a) at Portland State University (PSU). Measured temperatures are from USGS stations 14159500,14150000 , and 14155500 for graphs $A, B$, and $C$, respectively. 


\section{Dexter and Lookout Point Dams}

Dexter Dam is a re-regulating dam located just downstream of Lookout Point Dam on the Middle Fork (MF) Willamette River not far from Eugene, Oregon (fig. 1). Lookout Point Dam impounds one of the two largest storage reservoirs in the Willamette River basin and has a large upstream drainage area that encompasses portions of both the Western Cascades and the High Cascades. The MF Willamette River and its major tributaries - the North Fork of the Middle Fork (NFMF) Willamette River, Salt Creek, and Salmon Creek-all have contributing areas in the High Cascades.

The process of estimating without-dam water temperatures at the Dexter dam site had to begin upstream of Hills Creek Dam, also on the MF Willamette River. The first step was to determine the availability of water-temperature data upstream of Hills Creek Dam and in the other major tributaries (Salt Creek, Salmon Creek, and the NFMF Willamette River), and then work downstream by applying energy and mass balances at each major tributary confluence. Measured temperatures upstream of Hills Creek Lake were available from Hills Creek (LASAR site 27974) and from the MF Willamette River upstream (LASAR site 27992) for most of June through September 2001. Streamflow data for Hills Creek were not available, so the energy balance for the Hills Creek and MF Willamette River confluence was done by weighting the measured temperatures with their upstream drainage areas $\left(59.9 \mathrm{mi}^{2}\right.$ upstream of the Hills Creek site, and $330 \mathrm{mi}^{2}$ upstream of the MF Willamette River site) after first accounting for summertime warming as water moved from the two temperature-measurement sites to the Hills Creek dam site. The Hills Creek and MF Willamette River sites are 7.5 and 13.4 mi upstream of that confluence, respectively. A maximum downstream warming rate of $0.11^{\circ} \mathrm{C} / \mathrm{mi}$ was applied as described previously, using thresholds of 10 and $16{ }^{\circ} \mathrm{C}$ for no warming and maximum warming.

Downstream of the Hills Creek dam site, water-temperature data were available from Salt Creek (LASAR site 28010) and from the mouth of the NFMF Willamette River (LASAR site 28003), but no temperature data from Salmon Creek and no flow data from any of these tributaries were available. Temperatures from Salmon Creek, therefore, were assumed to be similar to those from Salt Creek and the NFMF Willamette River, and the combined flow contribution of these tributaries was determined by subtracting the without-dam streamflow at the Hills Creek dam site from the without-dam streamflow at the Dexter dam site. When temperature data were available from Salt Creek and the NFMF Willamette River (June 7-September 30, 2001), their upstream drainage areas (114 and $248 \mathrm{mi}^{2}$, respectively) were used as weighting factors in an energy balance computation after accounting for the downstream warming of the Salt Creek water from its measurement site to the confluence of the NFMF with the MF Willamette River (6.4 mi). The combined flow and temperature effects of these tributaries then were merged with the without-dam flow and temperature in the MF Willamette River, again accounting for any downstream warming that would occur from the Hills Creek dam site to the confluence of the NFMF and MF Willamette Rivers. Finally, downstream warming estimates from that location to the Dexter dam site $(20.8 \mathrm{mi})$ were applied, with a maximum warming rate of $0.11^{\circ} \mathrm{C} / \mathrm{mi}$ and minimum and maximum thresholds of 10 and $16^{\circ} \mathrm{C}$ as before. This calculation resulted in without-dam temperature estimates at the Dexter dam site for June 4-September 30, 2001. Far fewer data were available from these or similar sites in 2002; therefore, 2002 withoutdam temperatures at the Dexter dam site could not be derived from upstream temperature measurements.

To extend the without-dam temperature estimates for summer 2001 at the Dexter dam site to the rest of 2001-02, regressions of those estimates with measured temperatures at other sites were constructed. Daily mean and daily range regressions were tested using water-temperature data from the two long-term USGS sites used previously in this study: Blowout Creek in the North Santiam River basin and SF McKenzie River upstream of Cougar Reservoir. Both regressions provided relatively good models for predicting without-dam temperatures at the Dexter dam site, with correlation coefficients greater than 0.91 and 0.76 for the daily mean and daily range models, respectively. The SF McKenzie River regression, however, produced temperature estimates that were biased slightly high in spring and early summer and slightly low in late summer. In contrast, the Blowout Creek regression produced temperature estimates that were too high 
in late summer and early autumn. Mean absolute errors were 0.92 and $1.03{ }^{\circ} \mathrm{C}$ for the SF McKenzie River and Blowout Creek regressions, respectively. Averaging the results from the two regressions eliminated some of the bias from each and reduced the MAE to $0.59^{\circ} \mathrm{C}$. Therefore, the average of the two regressions was used to estimate without-dam water temperatures at the Dexter dam site for January 1-June 3 and October 1-December 31, 2001 and for the entire year in 2002. The final combined regression equation is:

$$
\begin{aligned}
T_{D X}= & \left(0.080762 T_{m S F}^{2}+0.63471 T_{m S F}\right. \\
& +1.7792\left(T_{S F}-T_{m S F}\right)+0.13038+1.1733 T_{m B C} \\
& \left.+1.1941\left(T_{B C}-T_{m B C}\right)\right) / 2,
\end{aligned}
$$

where

$T_{D X}$ is the without-dam temperature estimate at the Dexter dam site,

$T_{S F}$ and $T_{B C}$ are the measured half-hourly temperatures at the SF McKenzie River and Blowout Creek sites, and

$T_{m S F}$ and $T_{m B C}$ are the daily mean temperatures at those two sites, respectively.

This regression indicates that the daily range in without-dam temperature at the Dexter dam site is about 78 percent larger than the measured range at the SF McKenzie River site, and about 19 percent larger than the measured range at Blowout Creek.

For 2002, few measured water temperatures upstream of Lookout Point Lake were available, but some data from the MF Willamette River upstream of Hills Creek Lake were used to check the regression estimates at Dexter. The measured MF Willamette River temperatures upstream of Hills Creek Lake (LASAR site 30500) were compared to regression results at the Dexter dam site after applying the same type of downstream warming to the measured temperatures, using a maximum warming rate of $0.11^{\circ} \mathrm{C} / \mathrm{mi}$ over $40.4 \mathrm{mi}$. The comparison was favorable, with relatively good agreement for the daily maximum temperature in mid-summer and good agreement in general for April through June. The estimated without-dam temperatures are compared to the measured with-dam temperatures at the Dexter dam site in figure $9 B$.

The patterns for with- and without-dam temperatures at the Dexter dam site are somewhat similar to those from the Cottage Grove dam site. Annual maximum without-dam 7dADM temperatures at Dexter are approximately $23.5^{\circ} \mathrm{C}$, similar to those at Cottage Grove, whereas the with-dam annual maximum 7dADM temperatures at Dexter ranged from 18.8 to $20.4{ }^{\circ} \mathrm{C}$ (table 4 ). The shift in annual maximum temperature from July or August to September as a result of the dams is evident at Dexter just as it is at most of the other dam sites. Without-dam temperature estimates are warmer at Dexter than at the Blue River, Cougar, or Big Cliff dam sites because of the lower elevation of Dexter and the greater distance downstream from its cold High Cascade headwaters.

The greatest uncertainties in the without-dam temperature estimates at the Dexter dam site probably result from the downstream warming rate that was applied, despite the fact that the maximum warming rate applied in this study was an exact match to the warming gradient measured in the MF Willamette River in July-September of 1951-53 (Moore, 1967) prior to the completion of Lookout Point, Dexter, and Hills Creek Dams. Given the large distance over which the warming rate was applied (20.8 mi from the North Fork confluence, as far as $42 \mathrm{mi}$ from the MF Willamette River site upstream of Hills Creek Lake), a small error in the warming rate might produce a significant error in the estimated withoutdam temperature at Dexter. An error of $0.03{ }^{\circ} \mathrm{C} / \mathrm{mi}$, for example, would result in a predictive error of $0.6-1.1^{\circ} \mathrm{C}$ at Dexter during mid-summer, which may be sufficient reason to justify the construction of river models to provide a better prediction of the warming rate. Still, applying measurement error, regression error, and potential errors in the estimated downstream warming rate, the uncertainty in the without-dam temperatures at Dexter are likely to be no more than $1.5^{\circ} \mathrm{C}$ most of the time (table 5). 


\section{Dorena Dam}

Dorena Dam is located on the Row River near Cottage Grove, Oregon. Completed in 1949, the dam impounds a relatively small reservoir compared to most of the other USACE dams in the Willamette River basin, but still more than twice the storage of nearby Cottage Grove Lake. The upstream drainage area is entirely within the Western Cascades physiographic area, but the dam site is at an elevation of only about $800 \mathrm{ft}$ above sea level, which is only slightly higher than the elevation of the Cottage Grove dam site but about $400 \mathrm{ft}$ lower than the Blue River dam site.

Measured water temperatures were available for the Row River upstream of Dorena Lake (LASAR site 28613) for August 2-September 26, 2001, and April 21-September 9, 2002. A maximum downstream warming rate of $0.11^{\circ} \mathrm{C} / \mathrm{mi}$ was applied to account for the heating that normally would occur as the water moved from the temperature-measurement site downstream $6 \mathrm{mi}$ to the Dorena dam site.

To help estimate without-dam water temperatures for the rest of 2001 and 2002, nearby measurements of water temperature were examined. For June 21-October 3, 2001, measured temperatures from Mosby Creek downstream of Row River Trail (LASAR site 28103) were obtained from ODEQ. The Mosby Creek temperatures appeared to have a larger daily variation than the Row River temperatures. Therefore, the daily means and daily ranges of these two datasets were correlated separately, and the resulting regression was obtained:

$$
\begin{aligned}
T_{R R}= & 1.8147+0.97575 T_{m M C} \\
& +\left(T_{M C}-T_{m M C}\right)\left(0.14626+0.58866 T_{r M C}\right) / T_{r M C},
\end{aligned}
$$

where

$$
\begin{aligned}
& T_{R R} \text { is the estimated without-dam Row River } \\
& \text { temperature, } \\
& T_{m M C} \text { is the measured daily mean temperature of } \\
& \text { Mosby Creek, } \\
& T_{M C} \text { is the half-hourly temperature of Mosby } \\
& \text { Creek, and } \\
& T_{r M C} \text { is the daily temperature range at the Mosby } \\
& \text { Creek site. }
\end{aligned}
$$

Correlation coefficients for the daily mean and daily range regressions were 0.989 and 0.747 , respectively. This regression was used to estimate Row River without-dam temperatures for June 21-August 2 and September 26October 3 of 2001, and it produced a good match to both the mean and range of the measured Row River temperatures.

Extending the without-dam predictions to winter, spring, and autumn, a correlation with SF McKenzie River temperature data upstream of Cougar Reservoir for 2001 was constructed, also using separate regressions for the daily mean and daily range. The correlation produced the following equation:

$$
\begin{aligned}
T_{R R}= & -1.2996+1.9892 T_{m S F} \\
& +\left(T_{S F}-T_{m S F}\right)\left(0.29507+0.87489 T_{r S F}\right) / T_{r S F} .
\end{aligned}
$$

where the variables are similar to those from the previous equation, except the $S F$ subscript refers to data from the $\mathrm{SF}$ McKenzie River site. Again, the regression provided a good fit (correlation coefficients of 0.945 and 0.852 for the daily means and daily ranges, respectively), and this equation was used to estimate without-dam Row River temperatures for January 1-June 21 and October 3-December 31, 2001.

For 2002, measured water temperatures were available from nearby Mosby Creek at Laying Road (LASAR site 30638) for June 20-November 19. A regression of the Mosby Creek data against the without-dam Row River temperatures gave the following result:

$$
T_{R R}=2.095+0.97023 T_{M C}, R=0.935 \text {. }
$$

This regression provided a good fit to the available withoutdam temperatures in 2002 and was used to extend the estimates from September 9 to November 19. To extend the estimates to the rest of 2002, a correlation with SF McKenzie River temperatures upstream of Cougar Reservoir again was constructed. This time, however, only the 2002 without-dam estimates from April 21 to June 9 were used; using all available 2002 without-dam Row River temperatures did not produce as good a correlation. The resulting regression equation is:

$$
T_{R R}=-1.37+1.8196 T_{m S F}+\left(T_{S F}-T_{m S F}\right), R=0.895 .
$$

This regression was used to estimate without-dam Row River temperatures in 2002 for January 1-April 21 and November 19-December 31.

The final compilation of without-dam temperature estimates at the Dorena dam site shows patterns and extremes that are similar to those at the nearby Cottage Grove dam site (fig. 9C). The annual maximum without-dam 7dADM temperatures at Dorena are the warmest of all dam sites included in this study, exceeding $25^{\circ} \mathrm{C}$. Cooler temperatures occur with the dam in place, despite the lack of a natural seasonal pattern. Although these without-dam temperature estimates include the warmest temperatures estimated in this study, they are based on measured upstream and nearby temperatures, which decreases the inherent uncertainty of the estimates. Uncertainties associated with the withoutdam temperatures at the Dorena dam site are likely to be no more than $0.5^{\circ} \mathrm{C}$ in mid-summer (table 5), based on a typical measurement error of $0.2^{\circ} \mathrm{C}$ and a maximum warming estimation error of $0.3{ }^{\circ} \mathrm{C}(6 \mathrm{mi}$ times a potential error of $\left.0.05^{\circ} \mathrm{C} / \mathrm{mi}\right)$. 


\section{Fall Creek Dam}

Fall Creek Dam impounds a reservoir on Fall Creek about $7 \mathrm{mi}$ from its confluence with the MF Willamette River, and that confluence is about $5.5 \mathrm{mi}$ downstream of Dexter Dam (fig. 1). The dam site elevation is less than $700 \mathrm{ft}$ above sea level, and the upstream drainage area is located entirely within the Western Cascades physiographic area. Fall Creek Lake captures the inputs from Fall Creek as well as Winberry Creek, a major tributary that joins Fall Creek from the south and close to the dam site.

Without-dam water temperatures at the Fall Creek dam site were estimated first using measured temperatures upstream of Fall Creek Lake for the period of interest. Measured water temperatures were available from sites upstream of Fall Creek Lake on both Winberry Creek (LASAR site 28013) and Fall Creek (LASAR site 27969) for mid-June through mid-October 2001. Temperature data were not available for these creeks during 2002. USGS maintains a streamflow gage on Winberry Creek (station 14150800). Using measured flows in Winberry Creek and the estimated without-dam streamflow at the Fall Creek dam site, estimates of streamflow in Fall Creek were obtained by difference. Measured temperatures in Winberry Creek (7.7 mi upstream of the dam site) and Fall Creek (11.2 mi upstream of the dam site) were adjusted to account for a typical amount of downstream heating that would occur during warm summer periods, using techniques previously described in the section, "Methods and Models."

To extend the without-dam temperature estimates to the rest of the 2001-02 period, a correlation of these estimated temperatures to measured temperatures at a site with similar characteristics was constructed. The only nearby unregulated stream site with a complete temperature dataset is the SF McKenzie River upstream of Cougar Reservoir; however, that river derives a substantial part of its flow from the snowmelt and spring-fed High Cascades, which does not match the characteristics of the Fall Creek and Winberry Creek drainages. A dataset from a site farther away, then, but from a stream whose drainage area is entirely in the Western Cascades, might be better suited for this correlation. To test this hypothesis, the Fall Creek without-dam temperature estimates were correlated to measured water temperatures from the SF McKenzie River upstream of Cougar Reservoir (USGS station 14159200) and from Blowout Creek near Detroit (USGS station 14180300). Both tests correlated the daily means and daily ranges separately. The Blowout Creek regression produced better predictions (MAE of $0.71{ }^{\circ} \mathrm{C}$ versus $0.93{ }^{\circ} \mathrm{C}$ for the $\mathrm{SF}$ McKenzie River regression), particularly early in the summer. The following equation from the Blowout Creek regression, therefore, was used:

$$
\begin{aligned}
T_{F C}= & 0.0064233 T_{m B C}^{2}+1.04106 T_{m B C} \\
& +\left(T_{B C}-T_{m B C}\right)\left(0.11331+0.55893 T_{r B C}\right) / T_{r B C},
\end{aligned}
$$

where

$T_{F C}$ is the estimated without-dam temperature at the Fall Creek dam site,

$T_{m B C}$ is the measured daily mean temperature at the Blowout Creek site,

$T_{B C}$ is the half-hourly temperature from Blowout Creek, and

$T_{r B C}$ is the daily temperature range from the Blowout Creek site.

Correlation coefficients for the daily mean and daily range regressions were 0.962 and 0.800 , respectively. This regression was used to estimate Fall Creek without-dam temperatures for January 1-June 12 and October 17December 31 of 2001 and for the entire year of 2002. A comparison of the estimated 2002 temperatures with data from nearby Little Fall Creek (LASAR site 28092), an unregulated stream in the adjacent drainage to the north, demonstrated that the without-dam temperature estimates for Fall Creek were representative, at least for the July-August period when data from Little Fall Creek were available.

Without-dam water temperature estimates for the Fall Creek dam site (fig. 10A) compare favorably with those from the Blue River dam site, another site with a drainage area entirely within the Western Cascades. The annual maximum without-dam 7dADM temperatures for these two sites are nearly identical, with those from Fall Creek slightly warmer at about $21.5^{\circ} \mathrm{C}$ (table 4). The without-dam temperatures have the same seasonal pattern as those from other sites with maximum temperatures occurring in July or August, whereas the with-dam temperatures are affected by dam operations and the choice of release point. It is obvious, for example, that the release point from Fall Creek Dam was changed to a point deeper in the reservoir on September 3, 2002, because the downstream temperature decreased abruptly at that time.

Errors in the without-dam temperature estimates at the Fall Creek dam site are derived from measurement error, errors in the application of the estimated downstream warming rate, and regression prediction errors. The downstream warming was applied over a relatively short distance $(7.7 \mathrm{mi}$ on Winberry Creek and 11.2 mi on Fall Creek), so an error of as much as $0.05^{\circ} \mathrm{C} / \mathrm{mi}$ would result in an error no larger than $0.6^{\circ} \mathrm{C}$. Measurement errors typically are no larger than $0.2^{\circ} \mathrm{C}$, and the mean absolute error associated with the Blowout Creek regression was $0.7^{\circ} \mathrm{C}$. Uncertainties associated with the without-dam temperatures, therefore, likely are no larger than 0.8 to $1.5^{\circ} \mathrm{C}$ (table 5) . 

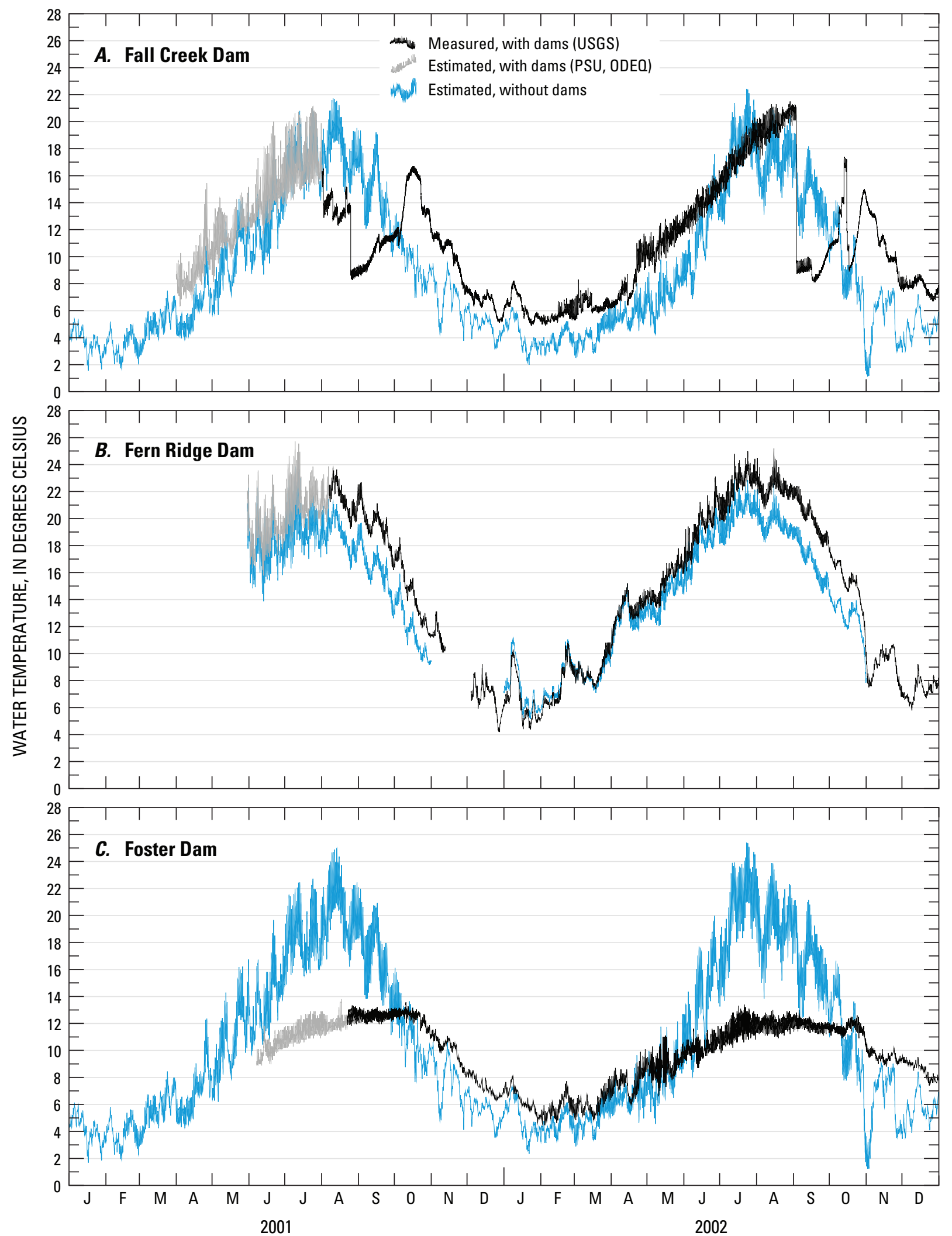

Figure 10. Measured and estimated water temperatures for conditions with and without upstream dams at the Fall Creek, Fern Ridge, and Foster dam sites in the Willamette River basin, Oregon, 2001-02. Estimated with-dam temperatures are from Annear and others (2004a) at Portland State University (PSU) for Fall Creek and Fern Ridge Dams or from correlations by the Oregon Department of Environmental Quality (ODEQ) for Foster Dam. Measured temperatures are from USGS stations 14151000,14169000 , and 14187200 for graphs $A, B$, and $C$, respectively. 


\section{Fern Ridge Dam}

Fern Ridge Dam is located on the Long Tom River northwest of Eugene, Oregon. At only $44 \mathrm{ft}$ high, it is the shortest dam included in this study, but it impounds almost as much water as Fall Creek Dam, which is four times taller. Upstream of the dam is Fern Ridge Lake, a large but shallow reservoir that has high value for wildlife and recreation in addition to providing flood control and irrigation water for downstream populations. The dam and lake are situated in the Willamette Lowlands physiographic area, with an upstream drainage area that extends into the Coast Range (fig. 2).

Few measured temperature data were available upstream of Fern Ridge Lake for 2001-02. Data were available from Coyote Creek, a tributary to the lake, and from a site on the Long Tom River 28.3 mi upstream of the dam. The Coyote Creek temperatures, however, appeared to be too warm to be representative of Long Tom River temperatures upstream of Fern Ridge Lake because mid-summer Coyote Creek temperatures were as warm as or warmer than measured temperatures downstream of Fern Ridge Dam. Similarly, the available upstream Long Tom River data were from a site that was far upstream and in a different physiographic province (Coast Range), characteristics making those data less representative of temperatures that would occur in the valley bottom. An alternate method of estimating without-dam temperatures at the Fern Ridge dam site was needed.

Temperature measurements upstream and downstream of Fern Ridge Lake from 1946 to 1962 were compiled and analyzed by Moore $(1964,1967)$ to assess the thermal effects of Fern Ridge Dam. The analysis was based on spot measurements, and the aggregated monthly results illustrate the heating effects of the lake in spring through autumn and the cooling effects in winter (fig. 11). A nonlinear equation was fitted to those data as an estimate of the heating or cooling effect of the lake as a function of the day of year.
Using measured temperatures just downstream of the dam, those heating or cooling effects of the lake could be removed by subtracting the fitted function in figure 11 to estimate water temperatures that might have occurred upstream of Fern Ridge Lake. Measured temperatures near the dam were available for all of 2002 and starting August 2001 from the USGS station at Alvadore (14169000). Temperatures for June and July 2001 were estimated for that site by PSU (Annear and others, 2004a).

After applying the reservoir-heating correction to estimate water temperatures upstream of Fern Ridge Lake, those results were used to estimate without-dam temperatures at the Fern Ridge dam site. A maximum downstream warming rate of $0.11^{\circ} \mathrm{C} / \mathrm{mi}$ was applied over the $11.9 \mathrm{mi}$ from the upstream site to the dam site for those times when warming was likely to occur.

With-dam annual maximum 7dADM temperatures at the Fern Ridge dam site are warmer than without-dam counterparts during 2001 and 2002, demonstrating that Fern Ridge Lake typically warms the Long Tom River during summer (table 4, fig. 10B). The seasonal temperature patterns for with- and without-dam conditions are similar, which is consistent with Fern Ridge Dam not being tall enough to keep and release any significant quantity of cold water at the bottom of Fern Ridge Lake. Errors inherent to the monthly heating and cooling pattern in figure 11 are on the order of $0.8^{\circ} \mathrm{C}$. Uncertainties in the without-dam temperature estimates for this site, however, probably are larger than $0.8^{\circ} \mathrm{C}$ because the process used to estimate temperatures upstream of the lake retains the daily temperature variations measured downstream of the dam, which are smaller than those that might occur in the absence of the dam. This method, therefore, underestimates the without-dam daily temperature range in mid-summer, resulting in errors that are likely to be about $1.0^{\circ} \mathrm{C}$ and at times perhaps as large as $2.0^{\circ} \mathrm{C}$ (table 5).

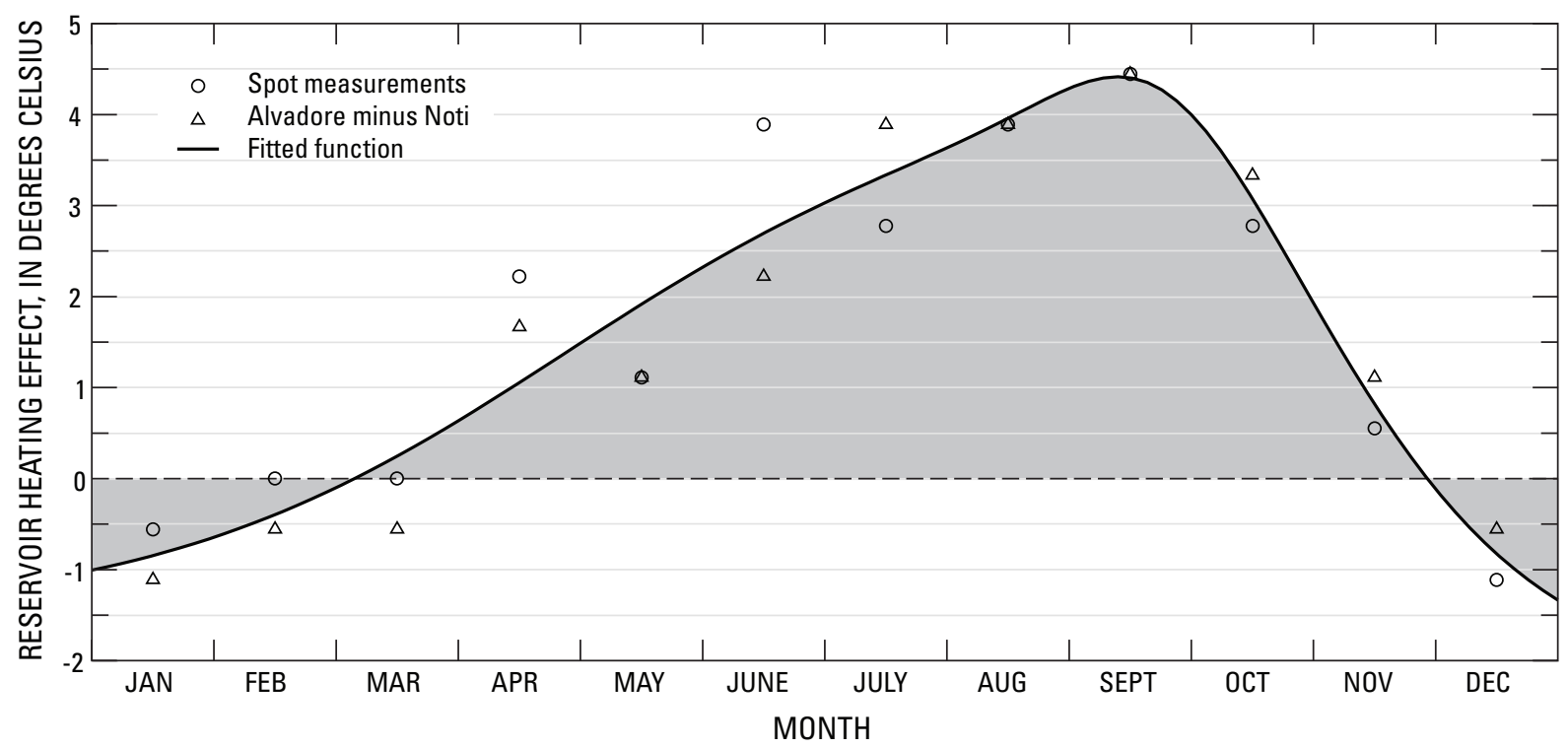

Figure 11. Measured heating effect of Fern Ridge Lake in the Willamette River basin, based on temperature measurements upstream and downstream of the lake. The first of two available datasets was documented by Moore (1967); the second was derived from measurements during 1946-62 at the USGS stations at Noti (upstream, 14166500) and at Alvadore (downstream, 14169000) (Moore, 1964). 


\section{Foster Dam}

Foster Dam is located on the South Santiam River near Sweet Home, Oregon, southeast of Albany. Foster Dam serves partially as a re-regulating dam downstream of the much larger Green Peter Dam on the Middle Santiam River. Foster Lake is a popular recreational area during summer. The upstream drainage area for both Foster and Green Peter Lakes lies entirely within the Western Cascades physiographic region.

Estimation of without-dam water temperatures at the Foster dam site relied on methods similar to those used for the Dexter dam site. Foster and Dexter Dams have other dams upstream, so the estimation process began upstream of the most-upstream reservoir. In 2002, hourly water-temperature data upstream of Green Peter Lake were available from Quartzville Creek (LASAR site 10791) and the Middle Santiam River (LASAR site 23805), which are the two major inflows to the lake. Downstream of Green Peter Dam, the other major inflow to Foster Lake is the South Santiam River. Water-temperature data from the South Santiam River upstream of Foster Lake were available in 2002 from ODEQ (LASAR site 30514). Flow in the South Santiam River upstream of Foster Lake was estimated as the difference between the without-dam streamflows at the Foster and Green Peter dam sites, and flow in the Middle Santiam River upstream of Green Peter Lake was estimated as the without-dam flow at Green Peter minus the measured flow in Quartzville Creek at USGS station 14185900. A flow-weighted energy balance was used to combine these three temperature datasets, but only after accounting for the warming that would occur as water from each of these sites traveled downstream to the Foster dam site. The Quartzville Creek, Middle Santiam, and South Santiam temperature measurements sites were 17.6, 19.2, and $9.0 \mathrm{mi}$ upstream of Foster Dam, respectively. A maximum downstream warming rate of $0.11{ }^{\circ} \mathrm{C} / \mathrm{mi}$ was applied, with minimum and maximum thresholds of 10 and $16^{\circ} \mathrm{C}$ as applied previously for other sites. This method resulted in without-dam water temperatures at the Foster dam site for April 23-September 11, 2002. The datasets for Quartzville Creek and the South Santiam River for this time period had sizeable gaps. When data for Quartzville Creek were absent, the Middle Santiam River data were the only measurements of temperature upstream of Green Peter Lake. Similarly, when South Santiam River temperatures were absent, temperature estimates at the Foster dam site were derived only from data upstream of Green Peter Dam.

For 2001, a similar approach was used, but with data from slightly different sites. The measured temperatures in the Middle Santiam River upstream of Green Peter Lake in 2001 were rated as poor by ODEQ and therefore were not used. A comparison of the 2002 temperatures from Quartzville Creek and the Middle Santiam River showed great similarity, both in their daily means and daily ranges. Using only the Quartzville Creek data to represent temperatures upstream of Green Peter Lake, therefore, was justified. The temperature measurement site on the South Santiam River was at a different location in 2001 (LASAR site 28615, 5.1 mi upstream of Foster Dam).
Applying a flow-weighted energy balance and an appropriate level of downstream warming as described previously (maximum rate of $0.11{ }^{\circ} \mathrm{C} / \mathrm{mi}$, etc.), without-dam temperature estimates were obtained for August 3-September 28, 2001.

The without-dam temperature estimates at the Foster dam site were extended to the rest of 2001-02 using correlations to measured water temperatures at the Blowout Creek site in the North Santiam River basin (USGS station 14180300). The Blowout Creek site was a good choice because its drainage area and the drainage area upstream of Foster Dam are both entirely within the Western Cascades. Separate regressions were made for the 2001 and 2002 datasets, and the results were similar, demonstrating that the input datasets for the two time periods showed consistent patterns and magnitudes. A combined regression could have been constructed, but the results would not have been significantly different. Separate regressions were made for the daily means and daily ranges, and the following equations were determined:

$$
\begin{aligned}
T_{F}= & 0.0063134 T_{m B C}^{2}+1.1714 T_{m B C} \\
& +0.72656\left(T_{B C}-T_{m B C}\right), \text { for } 2001, \\
T_{F}= & 0.0036136 T_{m B C}^{2}+1.2431 T_{m B C} \\
& +0.79928\left(T_{B C}-T_{m B C}\right), \text { for } 2002,
\end{aligned}
$$

where

$$
\begin{aligned}
& T_{F} \text { is the without-dam temperature estimate at } \\
& \text { the Foster dam site, } \\
& T_{m B C} \text { is the measured daily mean temperature at the } \\
& \text { Blowout Creek site, and } \\
& T_{B C} \text { is the half-hourly temperature from Blowout } \\
& \text { Creek. }
\end{aligned}
$$

Correlation coefficients for the daily mean and daily range regressions were $0.977-0.997$ and $0.872-0.881$, respectively. If the datasets had been combined, it is clear that similar coefficients would have been derived, with the daily mean temperature at the Foster dam site approximately 20 percent higher than that at Blowout Creek, and a daily temperature range about 76 percent of the range at Blowout Creek.

The estimated without-dam temperatures at the Foster dam site are much warmer in mid-summer than the measured with-dam temperatures at Foster Dam (fig. 10C). The cooler measured temperatures are a direct result of the large volume of cold water released from Green Peter Dam upstream. The without-dam temperatures are similar to those derived for the Dorena, Dexter, and Cottage Grove dam sites, with annual maximum $7 \mathrm{dADM}$ temperatures of about $24.5^{\circ} \mathrm{C}$ (table 4). These maxima are substantially warmer than their with-dam counterparts (about $13.2^{\circ} \mathrm{C}$ ). Uncertainties in the without-dam temperature estimates at the Foster dam site are derived from measurement error $\left(0.2^{\circ} \mathrm{C}\right)$, inaccuracies in the applied downstream warming rates (as much as $0.8^{\circ} \mathrm{C}$ ), and regression error (approximately $0.6^{\circ} \mathrm{C}$ ). An approximate total uncertainty, therefore, is likely to be in the range of $0.8-1.5^{\circ} \mathrm{C}$ (table 5). 


\section{Green Peter Dam}

Green Peter Dam impounds Green Peter Lake on the Middle Santiam River upstream of Foster Lake. The two major inputs are Quartzville Creek and the Middle Santiam River, with the former providing about 30-40 percent of the flow during summer. The entire upstream drainage area lies within the Western Cascades (fig. 2). Flow data are available from a USGS gaging station on Quartzville Creek upstream of the lake (station 14185900). ODEQ temperature data are available at or near that streamflow-gaging station (LASAR site 10791) during parts of 2001-02, and USGS temperature data are available at the gaging station beginning in 2008 . Some temperature data also are available on the Middle Santiam River upstream of the lake (LASAR site 23805), but the data from 2001 were rated poor by ODEQ, and the 2002 data were comparable to the Quartzville Creek temperatures.

Although the 2002 without-dam temperature estimates at the Foster dam site were derived from both the Quartzville Creek and Middle Santiam River temperatures upstream of Green Peter Lake, the similarity of the temperatures at these sites and the longer record at the Quartzville Creek site led to a decision to base the without-dam temperatures at the Green Peter dam site only on the Quartzville Creek data. Using those data (August 3-September 28, 2001, April 23-May 31, 2002, and July $12-$ September 11,2002), a regression was developed with measured temperatures at the Blowout Creek site (USGS station 14180300), which is located in an adjacent drainage to the east. An excellent fit was derived, with a mean absolute error of only $0.44^{\circ} \mathrm{C}$ (see equation 19).

Without-dam temperatures at the Green Peter dam site were estimated using the measured and correlated Quartzville Creek temperatures upstream of Green Peter Lake. A maximum downstream warming rate of $0.11^{\circ} \mathrm{C} / \mathrm{mi}$ was applied over the $10.2 \mathrm{mi}$ distance from the temperature measurement site to the dam site (see section, "Methods and Models"). The resulting without-dam temperature estimates are plotted along with a limited dataset of measured temperatures at the Green Peter dam site in figure 12A. The without-dam temperatures at the Green Peter dam site are nearly identical to the without-dam temperature estimates at the Foster dam site, but slightly cooler. The without-dam temperatures at the Green Peter dam site fall neatly into a group with those from the Foster, Dexter, Dorena, and Cottage Grove dam sites, all of which are similar by having a substantial drainage area in the Western Cascades (table 4). Estimates for the Blue River dam site are slightly cooler, probably as a result of a higher elevation. Uncertainties in the Green Peter without-dam temperatures can be estimated on the basis of measurement error $\left(0.2^{\circ} \mathrm{C}\right)$, correlation error $\left(0.4^{\circ} \mathrm{C}\right)$, and error in the downstream warming rate $\left(<0.5^{\circ} \mathrm{C}\right)$, for a total range of approximately $0.5-1.0^{\circ} \mathrm{C}$ (table 5).

$$
\begin{aligned}
T_{Q C}= & 0.2533+1.1681 T_{m B C} \\
& +\left(T_{B C}-T_{m B C}\right)\left(0.0423 T_{r B C}^{2}+0.1955 T_{r B C}+0.8695\right) \\
& / T_{r B C},
\end{aligned}
$$

where

$T_{Q C}$ is the estimated temperature for Quartzville

Creek upstream of Green Peter Lake,

$T_{m B C}$ is the measured daily mean temperature at the

Blowout Creek site,

$T_{B C}$ is the half-hourly temperature from Blowout

Creek, and

$T_{r B C}$ is the daily temperature range from the Blowout

Creek site.

Correlation coefficients were 0.991 and 0.675 for the daily mean and daily range regressions, respectively. 

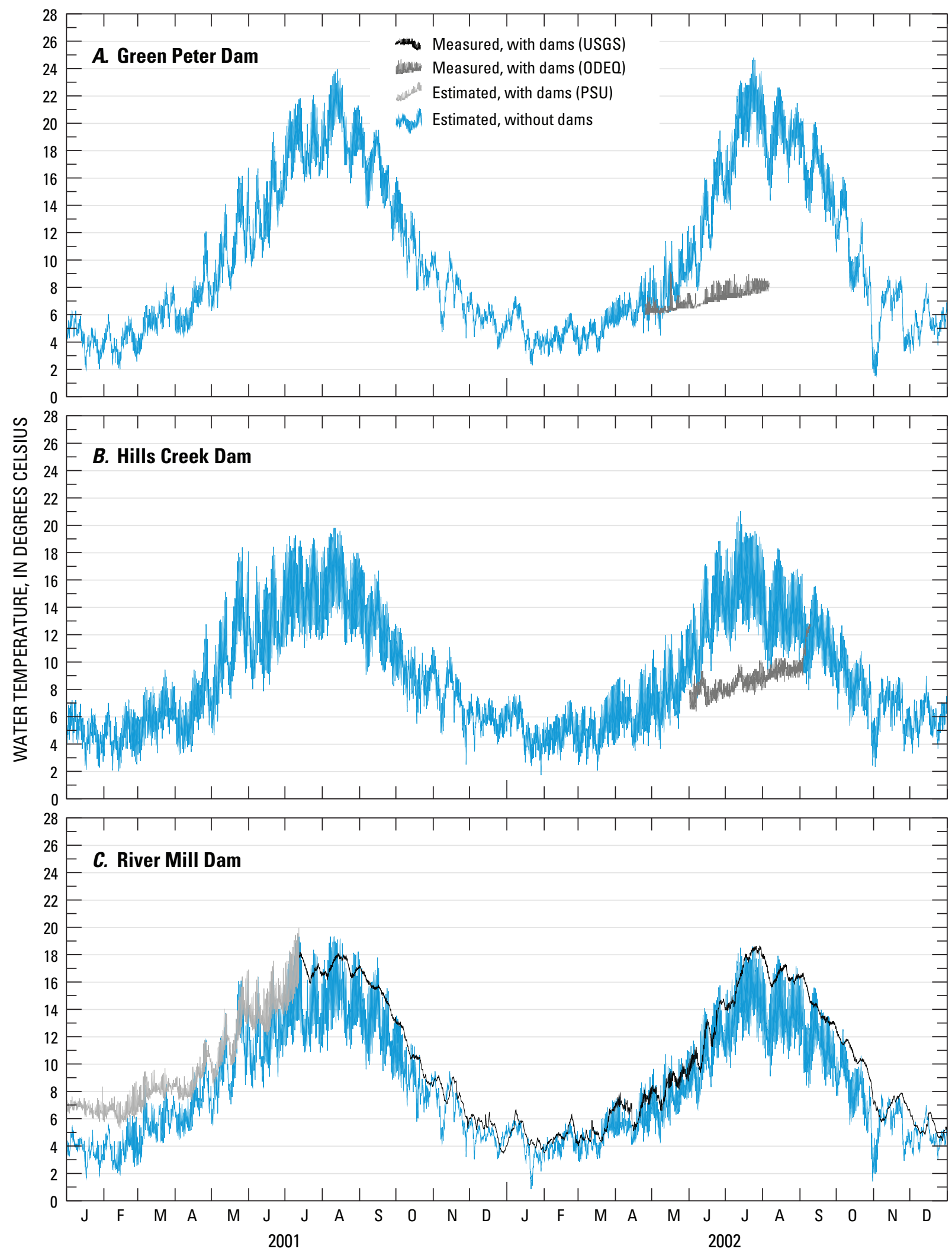

Figure 12. Measured and estimated water temperatures for conditions with and without upstream dams at the Green Peter, Hills Creek, and River Mill dam sites in the Willamette River basin, Oregon, 2001-02. Measured withdam temperatures are from the Oregon Department of Environmental Quality (ODEQ) for Green Peter and Hills Creek Dams and from USGS station 14210000 for River Mill Dam. Estimated with-dam temperatures for River Mill Dam are from Annear and others (2004a) at Portland State University (PSU). 


\section{Hills Creek Dam}

Hills Creek Dam is located on the MF Willamette River near Oakridge, Oregon, and upstream of both Dexter and Lookout Point Dams. Major inflows to the lake are from Hills Creek and the MF Willamette River. The Hills Creek drainage area primarily is in the Western Cascades, but the MF Willamette River extends up into the High Cascades. As a result, summertime inflows to Hills Creek Lake are fed partially by the snowmelt and colder springs of the High Cascades. Combined with an elevation of about $1,250 \mathrm{ft}$ above sea level, temperatures in the MF Willamette River at the Hills Creek dam site should be relatively cool in mid-summer compared to lower elevation sites and sites that do not derive flow from the High Cascades.

Without-dam temperatures at the Hills Creek dam site were derived from measured temperatures upstream of Hills Creek Lake. Temperature data were available for both Hills Creek (LASAR site 27982) and the MF Willamette River (LASAR site 27986) upstream of the lake for June 5-September 30, 2001, but temperature data were not available for Hills Creek for 2002. Streamflow data were not available for either inflow, but an energy balance could be derived by weighting those temperatures with their upstream drainage areas $\left(52.8 \mathrm{mi}^{2}\right.$ for Hills Creek, $258 \mathrm{mi}^{2}$ for the MF Willamette River) after accounting for the warming that was likely to occur from those sites to the dam site. A maximum downstream warming rate of $0.11^{\circ} \mathrm{C} / \mathrm{mi}$ was applied over a distance of $4.2 \mathrm{mi}$ from the Hills Creek site to the dam, and $8.5 \mathrm{mi}$ on the MF Willamette River.

To extend these temperature estimates to the entire 2001-02 time period, the without-dam data were correlated against measured temperatures in the SF McKenzie River above Cougar Reservoir (USGS station 14159200). A correlation to Blowout Creek data also was constructed, but the correlation to the SF McKenzie River data was better, with a mean absolute error of $0.51^{\circ} \mathrm{C}$ as opposed to $0.85^{\circ} \mathrm{C}$. This result is not surprising, as SF McKenzie River data are more representative of the magnitude and patterns of temperature in a High Cascades stream, whereas Blowout Creek data are more representative of temperatures in a Western Cascades stream. Separate regressions were constructed for the daily means and daily ranges, resulting in the following equation:

$$
\begin{aligned}
T_{H C}= & 0.0334 T_{m S F}^{2}+0.9345 T_{m S F} \\
& +\left(T_{S F}-T_{m S F}\right)\left(1.1604 T_{r S F}+1.2812\right) / T_{r S F},
\end{aligned}
$$

where

$T_{H C}$ is the estimated without-dam temperature at the Hills Creek dam site,

$T_{m S F}$ is the measured daily mean temperature at the SF McKenzie River site,

$T_{S F}$ is the half-hourly temperature from the SF McKenzie River site, and

$T_{r S F}$ is the daily temperature range from the SF McKenzie River site.

Correlation coefficients for the daily mean and daily range regressions were 0.931 and 0.889 , respectively.

The without-dam temperature estimates at the Hills Creek dam site have a similar seasonal pattern but are several degrees cooler in mid-summer than the withoutdam temperature estimates at the Dexter dam site (fig. 12B, fig. $9 B$ ). Annual maximum without-dam $7 \mathrm{dADM}$ temperatures at the Hills Creek dam site are less than $20^{\circ} \mathrm{C}$, cooler than all dam sites that have substantial drainage areas in the Western Cascades (Blue River, Cottage Grove, Dexter, Dorena, Fall Creek, Foster, Green Peter), but warmer than dam sites that have a substantial fraction of their drainage in the High Cascades (Big Cliff and Cougar). Uncertainties in the without-dam temperatures at the Hills Creek dam site are relatively small because errors in the downstream warming rate are accumulated over a short distance (maximum $8.5 \mathrm{mi}$, perhaps as large as $0.4^{\circ} \mathrm{C}$ ), and the correlation to $\mathrm{SF}$ McKenzie River temperatures was good (MAE $0.5^{\circ} \mathrm{C}$ ). A typical error in the without-dam estimates then should be no more than $0.5-1.0{ }^{\circ} \mathrm{C}$ (table 5). 


\section{River Mill Dam}

River Mill Dam is located on the Clackamas River near Estacada, Oregon, and is the most downstream of a series of hydropower projects owned and operated by Portland General Electric in the Clackamas River basin. Like the North Santiam and McKenzie Rivers, the Clackamas River derives some of its flow from the High Cascades but also has a substantial drainage area in the Western Cascades (fig. 2). The hydropower projects in the Clackamas River system recently underwent a relicensing process overseen by the Federal Energy Regulatory Commission (FERC). As part of that process and a related water-quality certification process through ODEQ, models of the Clackamas River were constructed to determine the flow and temperature effects of the hydropower projects. One of the model scenarios was a "no-project" scenario to simulate the river without the hydropower dams and diversions (Oregon Department of Environmental Quality, 2006b).

No-project temperature predictions from the Clackamas River model at the River Mill dam site from April 9, 2000, to September 30, 2001, were used as obtained from ODEQ to represent without-dam temperatures at that location. To cover the rest of 2001 and all of 2002, the no-project temperatures were correlated with measured temperatures at nearby sites. Five different correlation sites were tested using the 2001 no-project estimates including all three major inflows to Detroit Lake and a site on the Little North Santiam River in the adjacent North Santiam River basin to the south. The daily means and daily ranges were correlated separately to reduce timing (phase) errors. All tested regressions captured most of the seasonal pattern in the no-project temperatures, but the regression with North Santiam River temperatures upstream of Detroit Lake (USGS station 14178000) produced the best fit (MAE $0.61^{\circ} \mathrm{C}$ ). Expanding the dataset by adding the 2000 data did not improve the correlation.

The seasonal pattern in the daily temperature range from the North Santiam River site was not the best match for the seasonal pattern in the daily temperature range from the Clackamas River dataset. The North Santiam River regression produced a smaller daily range in late summer and early autumn than was evident in the Clackamas River dataset. A correlation with daily ranges from the Blowout Creek site provided a better match. The final regression, therefore, relied on daily mean temperatures from the North Santiam River upstream of Detroit Lake and daily temperature ranges from Blowout Creek, illustrating the wide variety of regression models that might be constructed. The final equation was:

$$
T_{R M}=-0.06208+1.1146 T_{m N S}+0.85051\left(T_{B C}-T_{m B C}\right),
$$

where

$T_{R M}$ is the estimated without-dam temperature at the River Mill dam site,

$T_{m N S}$ is the measured daily mean temperature in the North Santiam River upstream of Detroit Lake,

$T_{B C}$ is the half-hourly temperature from the Blowout Creek site, and

$T_{m B C}$ is the measured daily mean temperature from the Blowout Creek site.

Correlation coefficients were 0.993 and 0.902 for the daily mean and daily range regressions, respectively. This regression model produced an MAE of $0.55^{\circ} \mathrm{C}$, and was used to estimate without-dam temperatures at the River Mill dam site for September 30, 2001-December 31, 2002.

A comparison of the modeled and estimated without-dam and measured with-dam temperatures at or near the River Mill dam site shows a great similarity in the two datasets (fig. 12C). The seasonal patterns are nearly identical, and the annual maximum 7dADM temperatures are roughly comparable (table 4), but the measured temperatures downstream of River Mill Dam have a much smaller daily variation than the without-dam temperature estimates. The similar seasonal patterns probably are the result of the fact that the hydropower projects on the Clackamas River are largely run-of-the-river; they have limited storage capacity and therefore cannot store a large amount of heat absorbed in mid-summer for release later in the year. Most of the dams in the Clackamas River system, with the possible exception of North Fork Dam, also are not so tall that they generally release water from a hypolimnion that is colder than the surface water. The presence of the dams, however, may account for the lack of daily variation in the with-dams temperatures.

Uncertainties in the without-dam Clackamas River temperatures at the River Mill dam site derive from model error and correlation error. Although the correlation error was calculated to be approximately $0.6{ }^{\circ} \mathrm{C}$, the model error for the no-project scenario is somewhat unknown. It is likely that the model as calibrated to existing conditions had a typical error on the order of 0.5 to $1.0^{\circ} \mathrm{C}$, but the no-project scenario error is subject to additional uncertainty inherent to assumptions used to construct that model scenario. Uncertainties in these without-dam temperature estimates, therefore, are likely to be at least $1.0-1.6^{\circ} \mathrm{C}$ (table 5). 


\section{Downstream Effects of Willamette Basin Dams}

To determine the effects of Willamette River basin dams on streamflow and water temperature downstream of those projects, the suite of CE-QUAL-W2 models used as the basis of the Willamette River temperature TMDL were run for scenarios with and without the dams in place. These models simulate the entire Willamette River and its major tributaries up to the first major dam on each tributary (see fig. 1). Both scenarios were based on the NTP model runs from the TMDL, which specified that riparian vegetation was restored to a more natural state, instream hydropower projects and power diversions were eliminated (such as those along the McKenzie River and at Willamette Falls on the Willamette River), and point sources were removed. Water withdrawals, upstream dams, and a modern channel shape were retained in the NTP model scenario. To create the without-dams scenario, the upstream flow and temperature boundary conditions were simply switched from the with-dam datasets to without-dam datasets, leaving the rest of the models unchanged as much as possible.

Other than the upstream boundary conditions that were used to specify with- or without-dam conditions, several other modifications to the TMDL models were necessary to allow them to run under a no-dams scenario. For example, water withdrawals from the South Santiam River downstream of Foster Dam during mid-summer can exceed the streamflow that would occur in a no-dams scenario. To keep the river from going dry and enabling the model to run and remain stable in a no-dams scenario, those withdrawals had to be reduced. All withdrawals were eliminated if the flow at the Foster dam site was less than $88 \mathrm{ft}^{3} / \mathrm{s}\left(2.5 \mathrm{~m}^{3} / \mathrm{s}\right)$, and withdrawals were gradually increased to their full amount when flows at Foster were equal to or greater than $177 \mathrm{ft}^{3} / \mathrm{s}\left(5.0 \mathrm{~m}^{3} / \mathrm{s}\right)$. In addition, the total withdrawal rate was constrained to be less than 90 percent of the 5-day minimum flow at Foster.

For the Coast Fork / Middle Fork Willamette River model, modifications were needed for some of the ungaged tributary inputs that were used in the model calibration to adjust river flows to match measured flows. These water-balancing flows had been used in part to eliminate inconsistencies between measured upstream reservoir releases and downstream flow measurements. For the no-dams scenario, such adjustments were no longer entirely applicable, and their use in losing reaches caused the model to either dry up or become unstable. These flow adjustments as used in the calibrated model also were far too frequent (half-hourly) and contained many abrupt changes (spikes) in flow. To resolve these problems, the inputs for these flow-correcting features (model tributaries 2-11 and the distributed tributary in model branch 10) were smoothed to remove short-term spikes, and maximum losses to groundwater were limited late in the summer. These changes allowed the Coast Fork / Middle Fork Willamette River model to run under a no-dams scenario, but the resulting simulated flows in these reaches are far more uncertain than those in other parts of the model domain.

\section{Downstream Flows}

The presence of large flood-control and storage dams typically reduces annual peak flows and increases annual minimum flows downstream of those dams. This effect is easily discernible in the Willamette River through an examination of long-term measurements at the USGS streamflow-gaging stations at Albany (14174000) and at Salem (14191000), where historical records go back to 1892 and 1909, respectively (fig. 13). Most of the major dams in the Willamette River basin were constructed from 1941 to 1969 (table 1). That transition period shows a decrease in the magnitude of annual peak flows as well as a distinct increase in annual minimum flows from approximately 2,500 to $4,000 \mathrm{ft}^{3} / \mathrm{s}$ at Albany, and from 3,000 to $6,000 \mathrm{ft}^{3} / \mathrm{s}$ at Salem.

Simulated streamflows for the with- and without-dam model scenarios illustrate the expected flow-augmentation effects of the dams in mid- to late-summer. Streamflow in the Willamette River at Albany decreases to a minimum near $2,000 \mathrm{ft}^{3} / \mathrm{s}$ without the dams, whereas the with-dam scenario results in streamflows greater than $4,000 \mathrm{ft}^{3} / \mathrm{s}$ or even $5,000 \mathrm{ft}^{3} / \mathrm{s}$ for most of July-October (fig. 14). A similar effect occurs at Salem, where the without-dam streamflow decreases to a range near 2,500-3,000 $\mathrm{ft}^{3} / \mathrm{s}$, yet the with-dam streamflow maintains a minimum greater than $6,000 \mathrm{ft}^{3} / \mathrm{s}$. The operation of upstream dams for flood control and downstream navigation results in lower annual peak flows and higher minimum summer flows in the Willamette River. With the wealth of streamflow data going back to the 19th century at Willamette River gaging stations, a model was not necessary to verify these effects. Streamflow, however, affects travel times through the river system and can have an important effect on water temperature. 


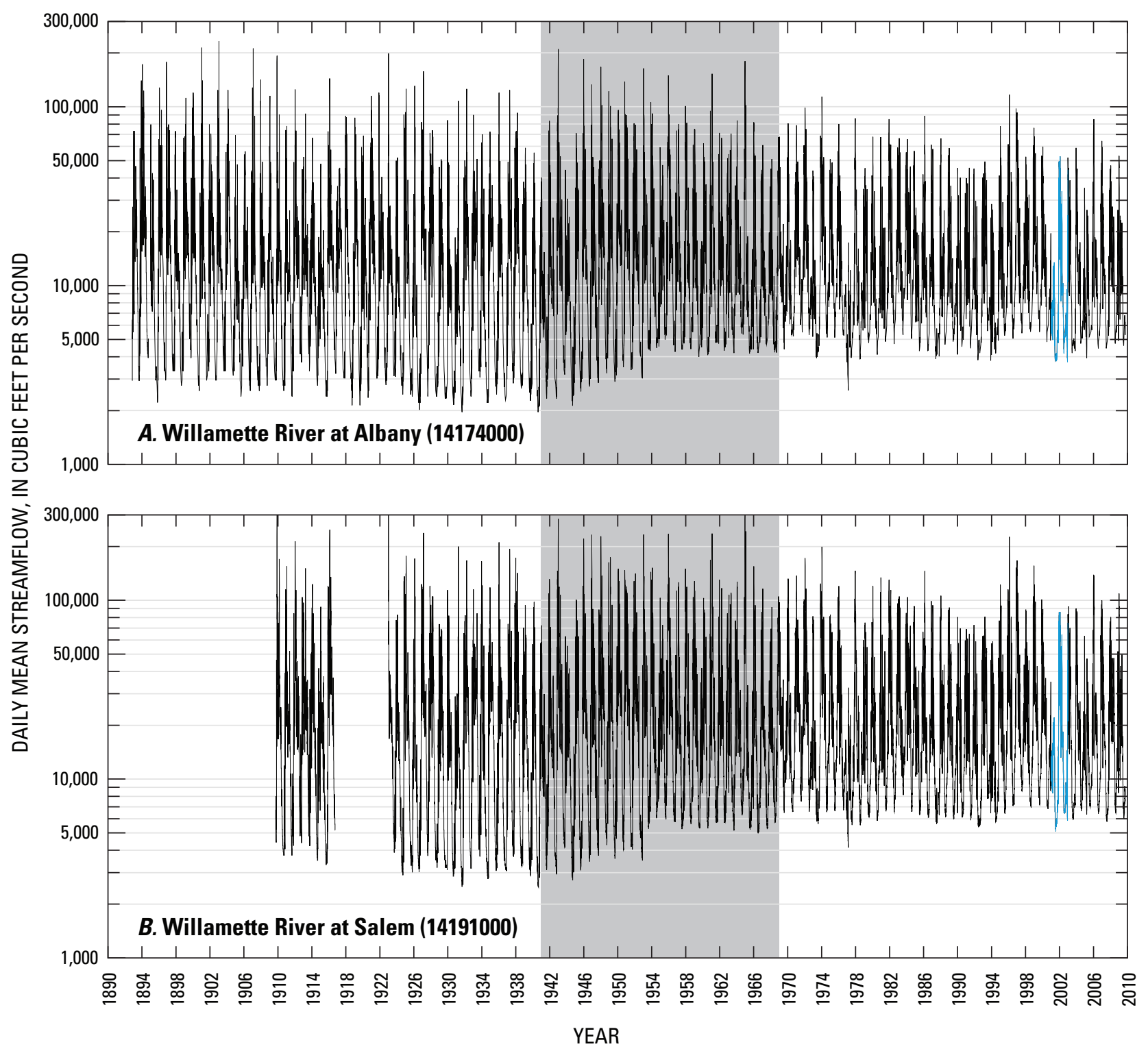

Figure 13. Measured daily mean streamflow at USGS gaging stations on the Willamette River at Albany (14174000, data starting 1892) and at Salem (14191000, data starting 1909). Streamflows during $2001-02$ are highlighted in blue. The largest upstream dams were constructed in the period 1941-1969 (shaded in gray). 


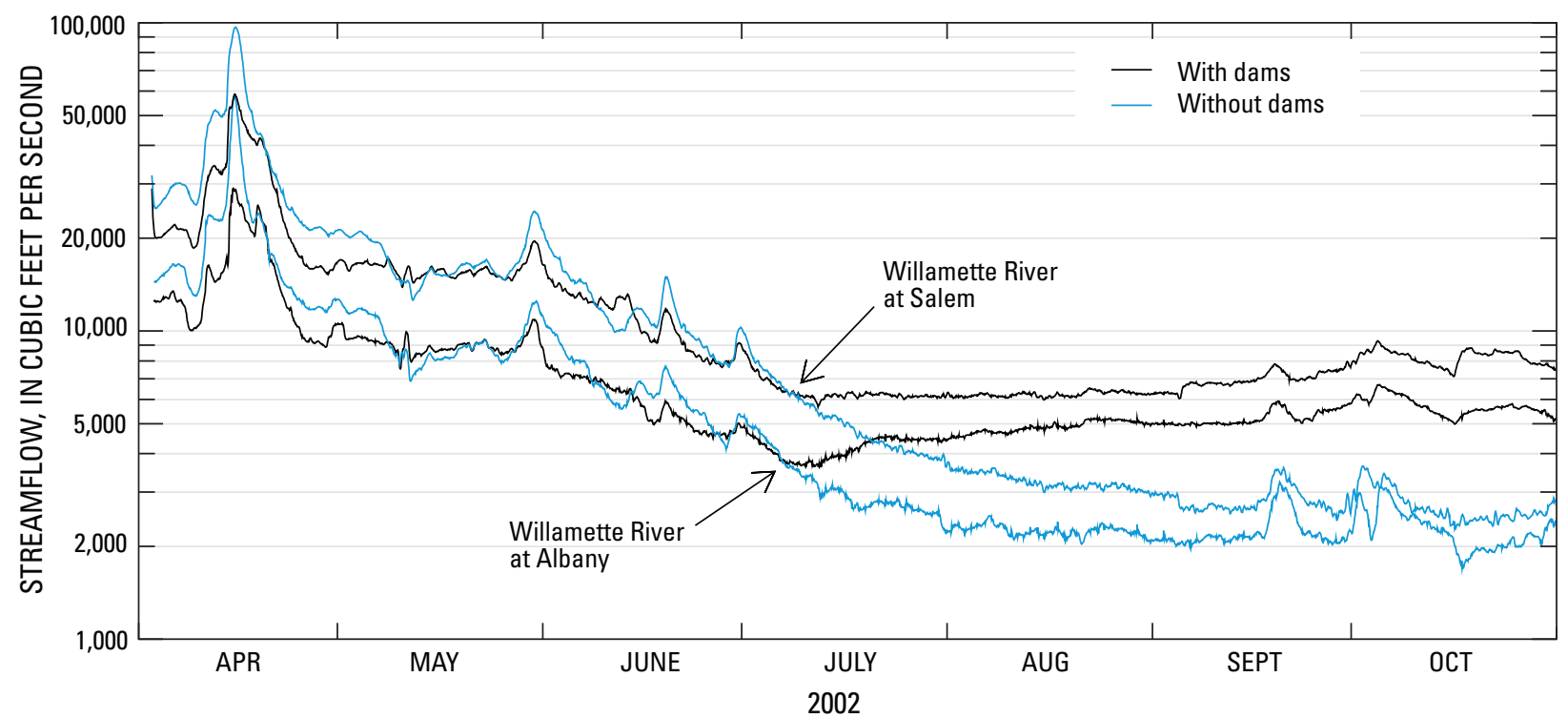

Figure 14. Simulated streamflow in the Willamette River at Albany and at Salem for conditions with and without upstream dams in the Willamette River basin, Oregon, April-0ctober 2002.

\section{Downstream Temperatures}

Upstream dams affect downstream temperatures through changes in the release temperatures at the dam sites as well as through changes in downstream flows. The presence or absence of upstream reservoirs affects downstream flows not only through reservoir releases but also as a result of changes to the regional groundwater system (Constantz and Essaid, 2007). Decreased flows in late summer in the absence of upstream dams results in longer travel times, allowing more time for river temperatures to respond to the influences of weather, water withdrawals, groundwater inputs, riparian shading, and point-source heating or cooling effects. Decreased flows also mean that less water is in the river, providing less thermal mass to resist changes in temperature and potentially altering the surface area to volume ratio, an important factor in determining the heat exchange flux per unit mass; a larger ratio enhances temperature changes due to surface heat-exchange processes. Because streamflowmodification effects on water temperature take time to occur, the effects are manifested well downstream of the dam sites. In contrast, alterations to stream temperature at a dam site provides an immediate heating or cooling effect that tends to dissipate with distance downstream as the river has time to exchange heat with its surroundings. These near- and far-field effects were explored and quantified by Risley and others (2010) for an idealized river system under several climate conditions, with and without upstream reservoirs and with varying groundwater inputs or losses, demonstrating that the far-field streamflow effects are just as important as the near-field release temperatures in determining the downstream thermal effects of dams.

For this study, modeled river temperatures for the withand without-dam scenarios were assessed using the 7dADM temperature, which is specified by Oregon's maximum water-temperature standard. The 7dADM temperature was calculated at every location in the model domain and for every day that was modeled in the June-October 2001 and April-October 2002 time period. The downstream temperature effects of the dams then were determined by subtracting the without-dams 7dADM temperatures from the with-dams $7 \mathrm{dADM}$ temperatures. The results are conveniently visualized by plotting the $7 \mathrm{dADM}$ temperature differences with a time/ distance color map as in figure 15 for the Willamette River. Similar plots for most of the other modeled reaches are included in appendix B. 


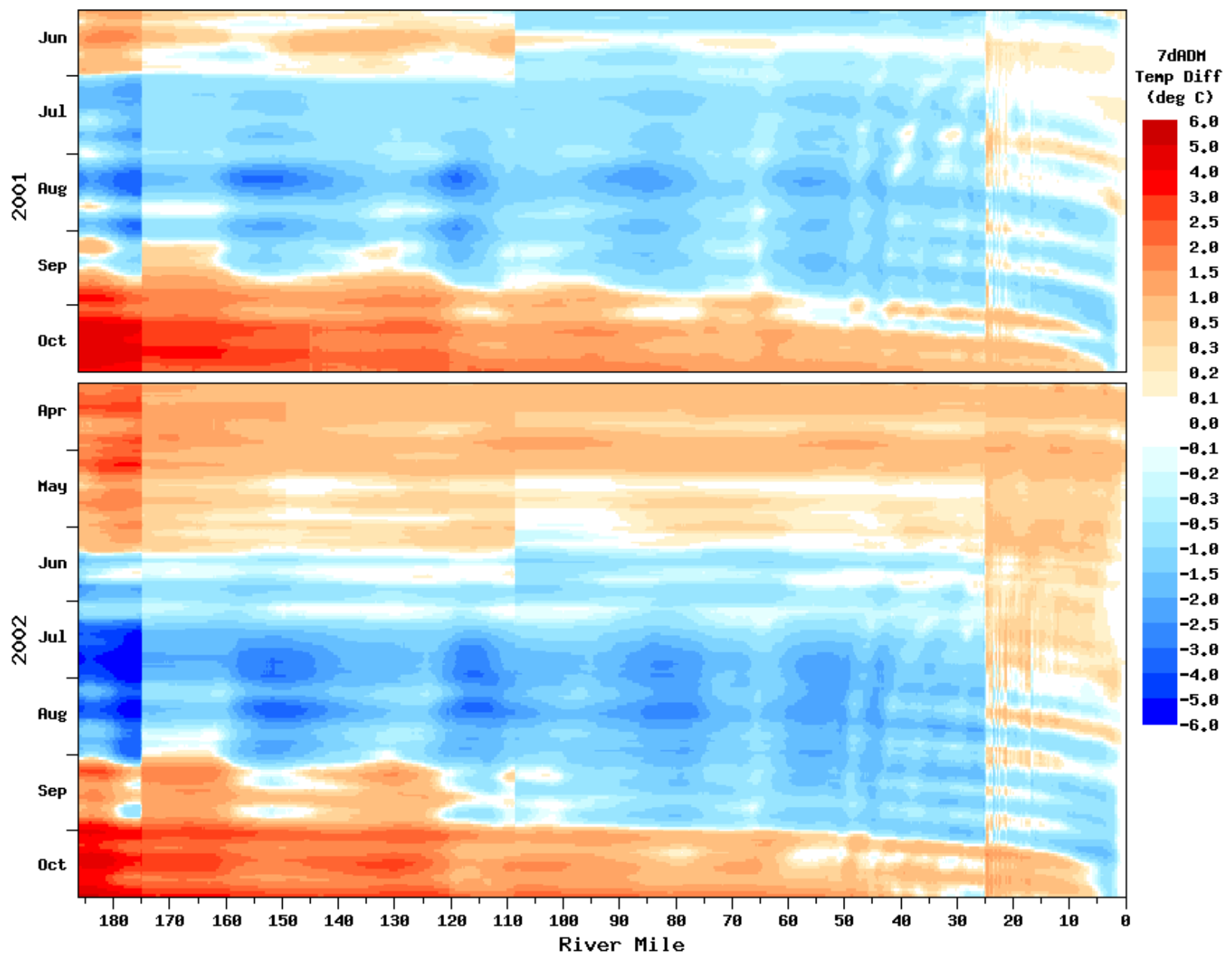

Figure 15. Modeled downstream thermal effects of dams on the entire Willamette River, Oregon, JuneOctober 2001 and April-0ctober 2002. Temperature changes in this figure are the difference in the modeled 7dADM temperatures for Natural Thermal Potential conditions with upstream dams minus the modeled 7dADM temperatures without upstream dams. The McKenzie, Long Tom, Santiam, and Clackamas Rivers join the Willamette River at river miles $174.9,149.4,108.5$, and 24.9 , respectively. 
Several important results and patterns can be derived from the color map showing the downstream temperature effects of the dams on the Willamette River. First, the pattern of cold-water releases in mid-summer and warmer releases in early autumn are apparent throughout the river. This pattern is most striking upstream of the McKenzie River confluence (RM 174.9) because that reach is closest to a series of upstream dams on the Middle Fork and Coast Fork Willamette River systems. Second, the magnitude of the temperature effect diminishes with downstream distance and dilution from tributaries. Upstream of the McKenzie River confluence, the effect can be more than 4 or $5{ }^{\circ} \mathrm{C}$, warming or cooling at different times of the year. Closer to the dams, the effect is even larger and can be sustained for longer periods (see appendix B). Downstream of the McKenzie River but upstream of the Santiam River (RM 108.5), the maximum effect decreases to less than 3 or $4{ }^{\circ} \mathrm{C}$ but more typically less than $1.5^{\circ} \mathrm{C}$. Downstream of the Santiam River, the maximum effect decreases further, to less than $2.5^{\circ} \mathrm{C}$ but more commonly less than $1^{\circ} \mathrm{C}$. Downstream of the Clackamas River confluence, the effect of upstream dams decreases to a level usually less than 0.5 or $1^{\circ} \mathrm{C}$. Third, the major tributary inflows do not necessarily dilute the effect of upstream dams because those tributaries also are affected by upstream dams. Several examples are evident in figure 15 where a cooling effect switches to warming, or vice versa, at a tributary junction because the effect of upstream dams in the tributary system can be larger than that in the Willamette River.

The time/distance color map for the Willamette River shows several periodic variations with downstream distance, particularly in the July through September period. These patterns are an artifact of using the daily maximum temperature in the analysis. Downstream of dams that release a relatively steady flow of water with little daily variation in temperature, as is the case for many of the larger dams in this study, a distinct downstream pattern in the daily maximum temperature can occur (Lowney, 2000). This pattern is characterized by minimal daily temperature variation at integer travel-time distances (1 day, 2 days, etc.), and maximum temperature variation in-between ( 0.5 day, 1.5 days, etc.). For example, a larger maximum can occur 0.5 days downstream of a dam because some water will reach that location after exposure only to heating during the day, whereas a full heating and cooling cycle is complete when that water has traveled a full day. In any case, the results from each model scenario contain a downstream nodal pattern in the $7 \mathrm{dADM}$ temperature where the period is related to 1 day of travel time. Computing the difference of two scenario results with different nodal distances (because the flows are different) then produces a new downstream pattern that is an artifact of using the $7 \mathrm{dADM}$ rather than a mean temperature.

To avoid problems associated with analyzing results that contain these travel-time artifacts, the distribution of 7dADM temperatures from each model scenario can be examined instead. These distributions for all modeled locations along the Willamette River are plotted in figure 16 for the June through October time periods of 2001-02. The lower plots ( $B$ and $C$ ) are simply histograms of the $7 \mathrm{dADM}$ temperatures from the without-dam and with-dam model scenarios, respectively, whereas the upper plot (fig. 16A) shows the cumulative frequency distribution for both scenarios. Similar plots for most of the other modeled reaches are included in appendix C. The histograms and the cumulative frequency plot for the Willamette River show a result that is shared by most of its tributaries. The with-dam 7dADM temperatures span a narrower range and tend to have higher minimum and lower maximum 7dADM temperatures than those without the dams. In the case of the Long Tom and Clackamas Rivers, however, the without-dam 7dADM temperatures tend to be cooler than the with-dam counterparts throughout the entire temperature range. These results, of course, depend on the without-dam flow and temperature estimates at the upstream dam sites; therefore, any errors in those estimates will affect the resulting without-dam temperature distributions.

Regardless of any errors in the modeled withoutdam temperatures, the general trends in the predictions are consistent with the physics of heat transport processes in river systems. The annual maximum temperatures at the dam sites are likely to be warmer without the dams because the reservoirs tend to buffer seasonal temperature changes and dam releases typically are not made from the warmer surface layer until later in the year after the reservoir begins to cool. Annual minimum temperatures also are likely to be cooler without the dams because it is far easier to cool a river in winter than it is to cool the bottom of a reservoir, which in the Willamette River basin is never likely to be colder than $4{ }^{\circ} \mathrm{C}$. Given these patterns at the dam sites, and coupled with lower flows during mid-summer without the dams, it is logical to expect that annual maximum temperatures downstream of the dam sites would be warmer without the dams. The wider temperature range without the upstream dams is an important result from this study. Despite the fact that all of the without-dam models use estimated temperatures at the dam sites, the results provide helpful guidelines for resource managers as they develop plans to manage dam operations for optimal fish habitat, among other goals. 

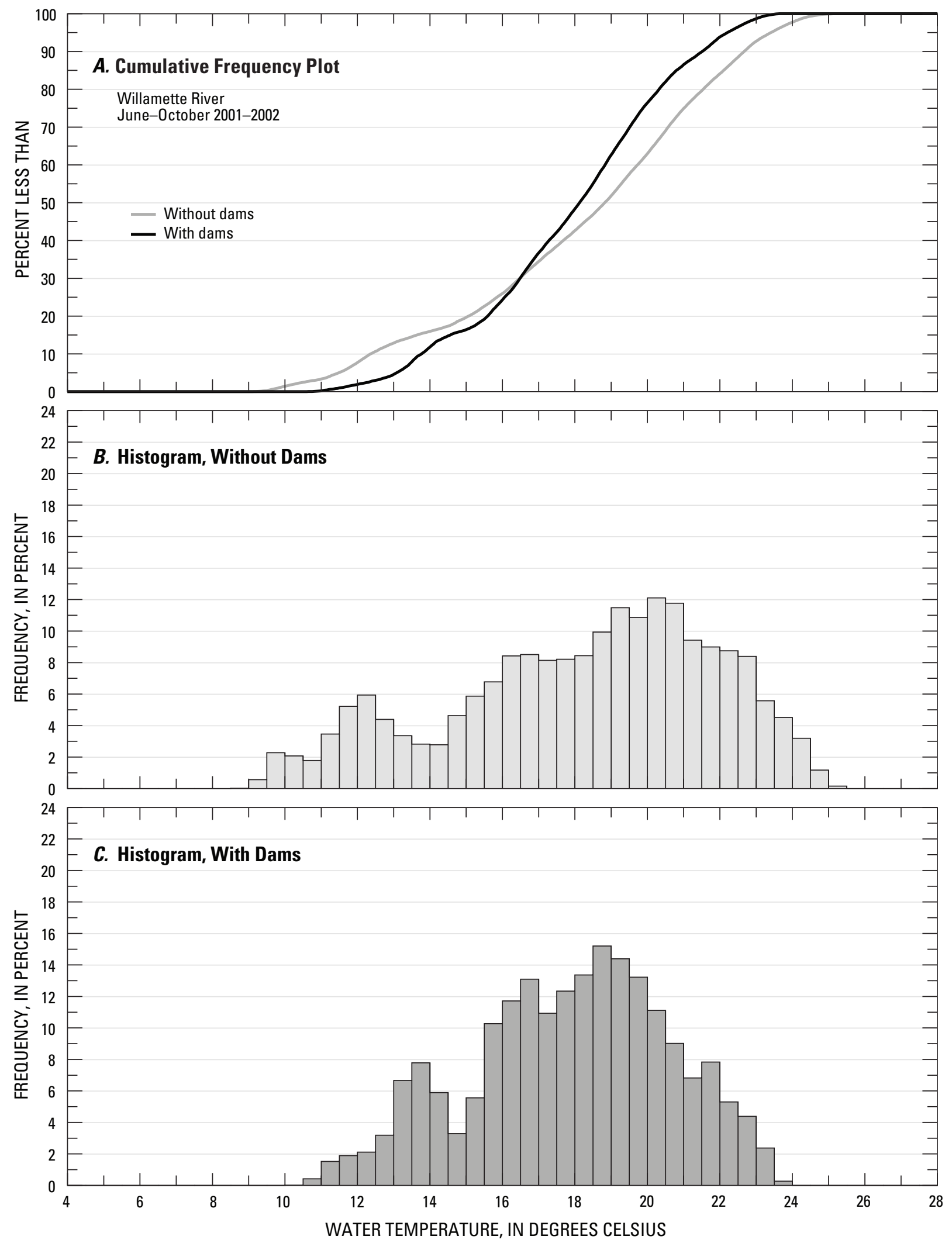

Figure 16. Modeled 7dADM temperatures for conditions with and without dams in the Willamette River downstream of the confluence of the Coast Fork and Middle Fork Willamette Rivers, Oregon, June-0ctober 2001-02. 


\section{Summary and Conclusions}

Regression techniques, mass and energy balances, measured water temperatures upstream of reservoirs, and modeled and historic rates of summertime warming with downstream distance were used to estimate the streamflows and water temperatures that likely would occur at 12 major dam sites in the Willamette River basin in the absence of those dams and any upstream dams. The dam sites include River Mill Dam on the Clackamas River as well as all major dams of the Corps of Engineers' Willamette Project. Because of short residence times in two re-regulating reservoirs, the effects of Big Cliff and Detroit Dams on the North Santiam River, and Dexter and Lookout Point Dams on the Middle Fork Willamette River, were combined and treated as single dam sites for this analysis. These without-dam streamflows and water temperatures were estimated for calendar years 2001 and 2002 to match the general time frame used in the Willamette River water-temperature Total Maximum Daily Load (TMDL) analysis. Estimated errors for the without-dam temperature estimates ranged from 0.5 to roughly $1.5^{\circ} \mathrm{C}$ for most of the dam sites in mid-summer, depending on the methods used, the availability of measured temperatures upstream of the reservoirs, and the amount of summertime warming applied through the reservoir reach.

The downstream effects of the dams were evaluated with a suite of CE-QUAL-W2 flow and temperature models by imposing both with- and without-dam streamflows and water temperatures at the dam sites as upstream boundary conditions. The models included the entire Willamette River and selected major tributaries up to their first major dams, were constructed and calibrated originally for the Willamette River water-temperature TMDL, and required several small modifications to allow them to run under the greatly changed without-dam streamflow conditions. The modeling time period for the TMDL and this analysis focused on the summertime low-flow period from April (2002) or June (2001) through October. Results were analyzed using the 7-day average of the daily maximum (7dADM) temperature, the statistic specified in the State of Oregon maximum water-temperature standard.

Many of the larger, taller dams in the Willamette River basin that are operated for flood control and hydropower generation have characteristic effects on streamflow and water temperature at the dam sites. The dams tend to reduce peak flows during precipitation or snowmelt time periods (for flood control) and augment streamflow during the summer low-flow period (for downstream navigation, irrigation, and other needs). Because the taller dams typically release water from a mid-depth or deeper outlet in the upstream impoundment, that water tends to be colder in mid-summer than it would be without the dam. In September or October, a large amount of water is released from many of these dams to make room for flood storage, which can bring warmer surface waters down to the elevation of the outlet, thus releasing the warmest water of the year during a time period when the river without the dam would be cooler because of shorter days and colder air temperatures. Many of the taller dams, therefore, tend to shift the annual maximum water temperature from July/August to September/October, and can release water that generally is 6 to $10^{\circ} \mathrm{C}$ cooler or warmer than what would occur without the dams.

The temperature effects of each dam are specific to the characteristics and operation of each structure. Starting in 2005, for example, Cougar Dam on the SF McKenzie River no longer produces a seasonal thermal shift because it was retrofitted with a selective withdrawal tower that allows operators to produce a more natural seasonal temperature pattern downstream of the dam. Detroit and Big Cliff Dams on the North Santiam River produced the typical seasonal shift in maximum temperature during the time period of this study, but were operated differently in 2008 and 2009, releasing water from multiple depths in Detroit Lake to produce a more natural pattern of downstream temperatures. A similar effect of releasing water from different outlets was apparent in the temperatures at Fall Creek Dam during the study period, where abrupt changes in the release temperature were indicative of a change in dam operations. Shorter dams, such as River Mill Dam on the Clackamas River and Fern Ridge Dam on the Long Tom River, do not exhibit a seasonal maximum temperature shift because the upstream reservoirs are not deep enough to provide a significant pool of cold hypolimnetic water at the dam outlet.

The degree to which the reservoirs are filled at the beginning of the summer season also is important in determining the temperature effects of the dams. Precipitation during the winter of 2000-01 was abnormally low and insufficient to fill most of the larger reservoirs in the Willamette River basin. The lower water level resulted in a shallower release, closer to the warmer epilimnion during summer, when using the normal release point from these dams. As a result, water released in mid-summer from several of the Willamette Project dams (Big Cliff/Detroit, Blue River, Dexter/Lookout Point, and Cottage Grove Dams in particular) was significantly warmer in 2001 than in 2002.

Estimation of without-dam water temperatures at the dam sites showed that the sites can be grouped according to their upstream drainage characteristics and elevation, a finding that is consistent with recent research by Tague and others (2007) for the McKenzie River basin. Sites that derive most of their flow from areas in the High Cascades, for example, tend to have cooler mid-summer temperatures because that water originates from snowmelt and cold spring complexes 
high in the mountains. This is the case for dam sites on the SF McKenzie River (Cougar Dam), the North Santiam River (Big Cliff and Detroit Dams), and to a slightly lesser degree, the upper reaches of the MF Willamette River (Hills Creek Dam) and the Clackamas River (River Mill Dam), although the latter site is at a lower elevation. Each of these sites produces without-dam mid-summer 7dADM temperature maxima less than $20^{\circ} \mathrm{C}$. The SF McKenzie River site is the coldest, with annual maximum $7 \mathrm{dADM}$ temperatures less than $15.5^{\circ} \mathrm{C}$, because it derives the greatest amount of flow from the High Cascades and is located at a relatively high elevation.

Sites that derive their flow from the Western Cascades, Coast Range, and Willamette Lowlands, areas that are affected more by rainfall than by snowmelt and lack the cold and consistent springs present in the High Cascades, tend to have warmer mid-summer temperatures, with annual maximum $7 \mathrm{dADM}$ temperatures greater than $21^{\circ} \mathrm{C}$ and as high as $25^{\circ} \mathrm{C}$. Sites at higher elevations, such as the Blue River dam site, tend to produce mid-summer temperatures at the low end of this range, whereas sites at lower elevations, such as Fern Ridge on the Long Tom River, Cottage Grove on the Coast Fork Willamette River, Foster on the South Santiam River, and Dorena on the Row River, tend to have warmer without-dam temperature estimates.

In order to address temperature issues related to dams and climate change, it is critical to maintain long-term yearround temperature monitors at key unregulated sites in several characteristic physiographic areas of the Willamette River basin. Currently, Blowout Creek near Detroit (USGS station $14180300)$ is one of the only long-term (10+ years), yearround temperature monitoring sites that is representative of conditions in the Western Cascades physiographic region. Several long-term, year-round temperature monitors exist at sites that are representative of conditions in High Cascades streams, such as the SF McKenzie River above Cougar Reservoir (USGS station 14159200), Breitenbush River above French Creek (USGS station 14179000), and the North Santiam River below Boulder Creek (USGS station 14178000). The latter two sites are upstream of Detroit Lake in the North Santiam River basin. New sites for temperature monitoring are being established at many sites throughout the Willamette River basin, including sites upstream of key reservoirs. Data from those sites will prove helpful for assessing basin-specific thermal characteristics, trends, and the effects of dams, but these new sites still have a relatively short period of record. Until datasets with longer period of records have been collected at these new sites, it is critical to maintain the few long-term temperature-monitoring sites that do exist.

Downstream of the dam sites, model results show that the effects of the dams persist to the mouth of the Willamette River, although the thermal effects diminish with downstream distance. The downstream thermal effects are caused by changes in both streamflow and water temperature at the dam sites. Without the dams, greatly decreased streamflow during the late summer months results in longer travel times through the river network, allowing additional time for the river to gain (or lose) heat from (to) its surroundings. Latesummer streamflow in the Willamette River is augmented by dam releases, increasing the flow at Albany and at Salem by approximately a factor of 2 or more during August, September, and October in 2001 and 2002. No attempt was made to separate the effects of altered streamflows relative to altered upstream temperatures on downstream water temperatures, but the effect of changes in streamflow are likely to be significant.

The thermal effects of the dams are greatest at the dam sites, where the $7 \mathrm{dADM}$ temperatures are as much as 6 to $10^{\circ} \mathrm{C}$ cooler or warmer compared to what would occur without the dams. Downstream, the effects decrease, but are still in the 0.5 to $1.0^{\circ} \mathrm{C}$ range near the mouth of the Willamette River, much larger than the cumulative point-source heating effect $\left(<0.3^{\circ} \mathrm{C}\right)$ regulated by the Willamette River temperature TMDL. Upstream of the Clackamas River but downstream of the Santiam River, the 7dADM temperature changes are on the order of $1{ }^{\circ} \mathrm{C}$, sometimes as high as $2.5^{\circ} \mathrm{C}$. Upstream of the Santiam River confluence, the effects of upstream dams on $7 \mathrm{dADM}$ temperatures in the Willamette River are on the order of $1.5^{\circ} \mathrm{C}$ but sometimes as high as 3 to $4{ }^{\circ} \mathrm{C}$. Clearly, the dams have an important effect on both streamflow and water temperature in the Willamette River and many of its major tributaries. Changes in dam operations have been used in recent years to greatly decrease those effects in the SF McKenzie River (Cougar Dam) and the North Santiam River (Detroit Dam). A quantification of the thermal effects of the dams both at the dam sites and downstream will be helpful as dam operators, resource managers, and regulators work to improve water quality and restore critical fisheries in the Willamette River basin.

\section{Acknowledgments}

This study was funded partially by the Portland District of the U.S. Army Corps of Engineers (USACE). Thanks to Jim Britton, Art Armour, and Mary Karen Scullion of USACE for providing funding, project coordination, and inflow and evaporation data for the USACE Willamette Basin projects. Thanks also to Janet Gillaspie and the Oregon Association of Clean Water Agencies, which had funded a previous Willamette River temperature modeling study that generated most of the without-dam temperature estimates. Finally, the author is grateful to the group of reviewers who provided helpful comments on this report. 


\section{References Cited}

Annear, R.L., McKillip, M.L., Khan, S.J., Berger, C.J., and Wells, S.A., 2004a, Willamette River Basin temperature TMDL model-Boundary conditions and model setup: Portland, Oreg., Portland State University, Department of Civil and Environmental Engineering, Technical Report EWR-01-04, 530 p.

Annear, R.L., McKillip, M.L., Khan, S.J., Berger, C.J., and Wells, S.A., 2004b, Willamette River Basin temperature TMDL model-Model scenarios: Portland, Oreg., Portland State University, Department of Civil and Environmental Engineering, Technical Report EWR-03-04, 944 p.

Berger, C.J., McKillip, M.L., Annear, R.L., Khan, S.J., and Wells, S.A., 2004, Willamette River Basin temperature TMDL model-Model calibration: Portland, Oreg., Portland State University, Department of Civil and Environmental Engineering, Technical Report EWR-02-04, 341 p.

Caissie, D., 2006, The thermal regime of rivers-A review: Freshwater Biology, v. 51, p. 1389-1406.

Cole, T.M., and Wells, S.A., 2002, CE-QUAL-W2: A twodimensional, laterally averaged, hydrodynamic and waterquality model, version 3.1: U.S. Army Corps of Engineers, Instruction Report EL-02-1 [variously paged].

Collier, Michael, Webb, R.H., and Schmidt, J.C., 1996, Dams and rivers - Primer on the downstream effects of dams: U.S. Geological Survey Circular 1126, 94 p. (Also available at http://pubs.er.usgs.gov/usgspubs/cir/cir1126.)

Conlon T.D., Wozniak, K.C., Woodcock, Douglas, Herrera, N.B., Fisher, B.J., Morgan, D.S., Lee, K.K., and Hinkle, S.R., 2005, Groundwater Hydrology of the Willamette Basin, Oregon: U.S. Geological Survey Scientific Investigations Report 2005-5168, 83 p. (Also available at http://pubs.usgs.gov/sir/2005/5168.)

Constantz, J.A., and Essaid, H.I., 2007, Influence of groundwater pumping on streamflow restoration following upstream dam removal: Hydrological Processes, v. 21, p. 2823-2834. (Also available at http://dx.doi.org/10.1002/ hyp.6520.)

Gregory, S.V., Ashkenas, Linda, and Nygaard, Chris, 2007, Summary report to assist development of ecosystem flow recommendations for the Coast Fork and Middle Fork of the Willamette River, Oregon: Institute for Water and Watersheds, Oregon State University, 237 p., accessed December 18, 2009 at http://hdl.handle.net/1957/5965.
Hansen, R.P., 1988, The effects of two multipurpose projects on the water temperature of the McKenzie River, Oregon: U.S. Geological Survey Water-Resources Investigations Report 87-4175, 34 p. (Also available at http://pubs.er.usgs. gov/usgspubs/wri/wri874175.)

Hulse, D.W., Gregory, S.V., and Baker, J.P., eds., 2002, Willamette River Basin Planning Atlas, trajectories of environmental and ecological change: Corvallis, Oreg., Pacific Northwest Ecosystem Research Consortium, Oregon State University Press, 178 p.

Laenen, Antonius, and Hansen, R.P., 1985, Preliminary study of the water-temperature regime of the North Santiam River downstream from Detroit and Big Cliff Dams, Oregon: U.S. Geological Survey Water-Resources Investigations Report 84-4105, 45 p. (Also available at http://pubs.er.usgs.gov/ usgspubs/wri/wri844105.)

Lowney, C.L., 2000, Stream temperature variation in regulated rivers - Evidence for a spatial pattern in daily minimum and maximum magnitudes: Water Resources Research, v. 36, no. 10 , p. 2947-2955.

Moore, A.M., 1964, Compilation of water-temperature data for Oregon streams: U.S. Geological Survey Open-File Report 64-115, 134 p. + 1 pl. (Also available at http://pubs.er.usgs. gov/usgspubs/ofr/ofr64115.)

Moore, A.M., 1967, Correlation and analysis of watertemperature data for Oregon streams: U.S. Geological Survey Water-Supply Paper 1819-K, 53 p. + 1 pl. (Also available at http://pubs.er.usgs.gov/usgspubs/wsp/ wsp1819K.)

National Marine Fisheries Service, 2008, Willamette Basin Biological Opinion-Endangered Species Act Section 7(a)(2) Consultation: NOAA Fisheries Log Number F/ NWR/2000/02117 [variously paged], accessed October 20, 2009, at http://www.nwr.noaa.gov/Salmon-Hydropower/ Willamette-Basin/Willamette-BO.cfm.

Oregon Department of Environmental Quality, 2006a, Willamette Basin Total Maximum Daily Load Order memorandum: Oregon Department of Environmental Quality, accessed September 24, 2009, at http://www.deq. state.or.us/wq/TMDLs/docs/willamettebasin/willamette/ ordermemo.pdf.

Oregon Department of Environmental Quality, 2006b, Willamette Basin Total Maximum Daily Load program documents: Oregon Department of Environmental Quality, accessed September 24, 2009, at http://www.deq.state.or.us/ wq/TMDLs/willamette.htm. 
Oregon Department of Environmental Quality, 2007, Laboratory Analytical Storage and Retrieval (LASAR) database: accessed June 1, 2010, at http://deq12.deq.state. or.us/lasar2/.

Oregon Department of Environmental Quality, 2009a, Water monitoring and assessment mode of operations manual: Oregon Department of Environmental Quality, Laboratory and Environmental Assessment Division, DEQ03-LAB0036-SOP, chap. 5 [variously paged], accessed March 8, 2010, at http://www.deq.state.or.us/lab/techrpts/docs/ DEQ03LAB0036SOP.pdf.

Oregon Department of Environmental Quality, 2009b, Water quality standards: Beneficial uses, policies, and criteria for Oregon-Temperature: Oregon Administrative Rule 340041-0028: Oregon Department of Environmental Quality, accessed November 13, 2009, at http://arcweb.sos.state. or.us/rules/OARs_300/OAR_340/340_041.html.

Rantz, S.E., and others, 1982, Measurement and computation of streamflow-Volume 2. Computation of discharge: U.S. Geological Survey Water Supply Paper 2175, 2 v., p. 285631. (Also available at http://pubs.usgs.gov/wsp/wsp2175.)

Risley, J.C., Constantz, J.A., Essaid, H.I., and Rounds, S.A., 2010, Effects of upstream dams versus groundwater pumping on stream temperature under varying climate conditions: Water Resources Research, v. 46, no. 6, W06517. (Also available at http://dx.doi. org/10.1029/2009WR008587.)

Rounds, S.A., 2007, Temperature effects of point sources, riparian shading, and dam operations on the Willamette River, Oregon: U.S. Geological Survey Scientific Investigations Report 2007-5185, 34 p. (Also available at http://pubs.usgs.gov/sir/2007/5185.)

Sullivan, A.B., and Rounds, S.A., 2004, Modeling streamflow and water temperature in the North Santiam and Santiam Rivers, Oregon, 2001-02: U.S. Geological Survey Scientific Investigations Report 2004-5001, 35 p. (Also available at http://pubs.usgs.gov/sir/2004/5001.)

Sullivan, A.B. and Rounds, S.A., 2006, Modeling waterquality effects of structural and operational changes to Scoggins Dam and Henry Hagg Lake, Oregon: U.S. Geological Survey Scientific Investigations Report 2006-5060, 36 p. (Also available at http://pubs.usgs.gov/ sir/2006/5060.)
Sullivan, A.B., Rounds, S.A., Sobieszczyk, Steven, and Bragg, H.M., 2007, Modeling hydrodynamics, water temperature, and suspended sediment in Detroit Lake, Oregon: U.S. Geological Survey Scientific Investigations Report 2007-5008, 40 p. (Also available at http://pubs.usgs.gov/ $\underline{\operatorname{sir} / 2007 / 5008 .)}$

Tague, Christina, Farrell, Michael, Grant, Gordon, Lewis, Sarah, and Rey, Serge, 2007, Hydrogeologic controls on summer stream temperatures in the McKenzie River basin, Oregon: Hydrologic Processes, v. 21, p. 3288-3300. (Also available at http://dx.doi.org/10.1002/hyp.6538.)

U.S. Army Corp of Engineers, no date, Dataquery: U.S. Army Corps of Engineers, Northwestern Division database: accessed June 1, 2010, at http://www.nwd-wc.usace.army. mil/perl/dataquery.pl.

U.S. Census Bureau, 2008, State and County QuickFacts: accessed October 21, 2009, at http://quickfacts.census.gov/ gfd/states/41000.html.

U.S. Geological Survey, 2007, StreamStats: accessed June 1, 2010, at http://water.usgs.gov/osw/streamstats/oregon.html.

U.S. Geological Survey, 2009, USGS Data Grapher and Data Tabler: accessed June 1, 2010, at http://or.water.usgs.gov/ grapher/.

U.S. Geological Survey, 2010a, National Water Information System (NWISWeb): U.S. Geological Survey database, accessed June 1, 2010, at http://waterdata.usgs.gov/nwis/.

U.S. Geological Survey, 2010b, USGS Surface-water data for Oregon: accessed June 1, 2010, at http://waterdata.usgs.gov/ or/nwis/sw/.

Wagner, R.J., Boulger, R.W., Jr., Oblinger, C.J., and Smith, B.A., 2006, Guidelines and standard procedures for continuous water-quality monitors - Station operation, record computation, and data reporting: U.S. Geological Survey Techniques and Methods 1-D3, 51 p. +8 attachments; accessed February 17, 2010, at http://pubs. usgs.gov/tm/2006/tm1D3/.

Wentz, D.A., Bonn, B.A., Carpenter, K.D., Hinkle, S.R., Janet, M.L., Rinella, F.A., Uhrich, M.A., Waite, I.R., Laenen, A., and Bencala, K.E., 1998, Water quality in the Willamette Basin, Oregon, 1991-95: U.S. Geological Survey Circular 1161, 34 p. (Also available at http://pubs.usgs.gov/circ/ circ1161.) 


\section{Appendixes}




\section{Appendix A. Graphs of Without-Dam Flow Estimates at Willamette River Basin}

Dam Sites Measured with-dam and estimated without-dam streamflows at the 12 dam sites of interest in this study are graphed in figures A1-A4. Without-dam streamflows were estimated using the techniques described in section, "Methods and Models."

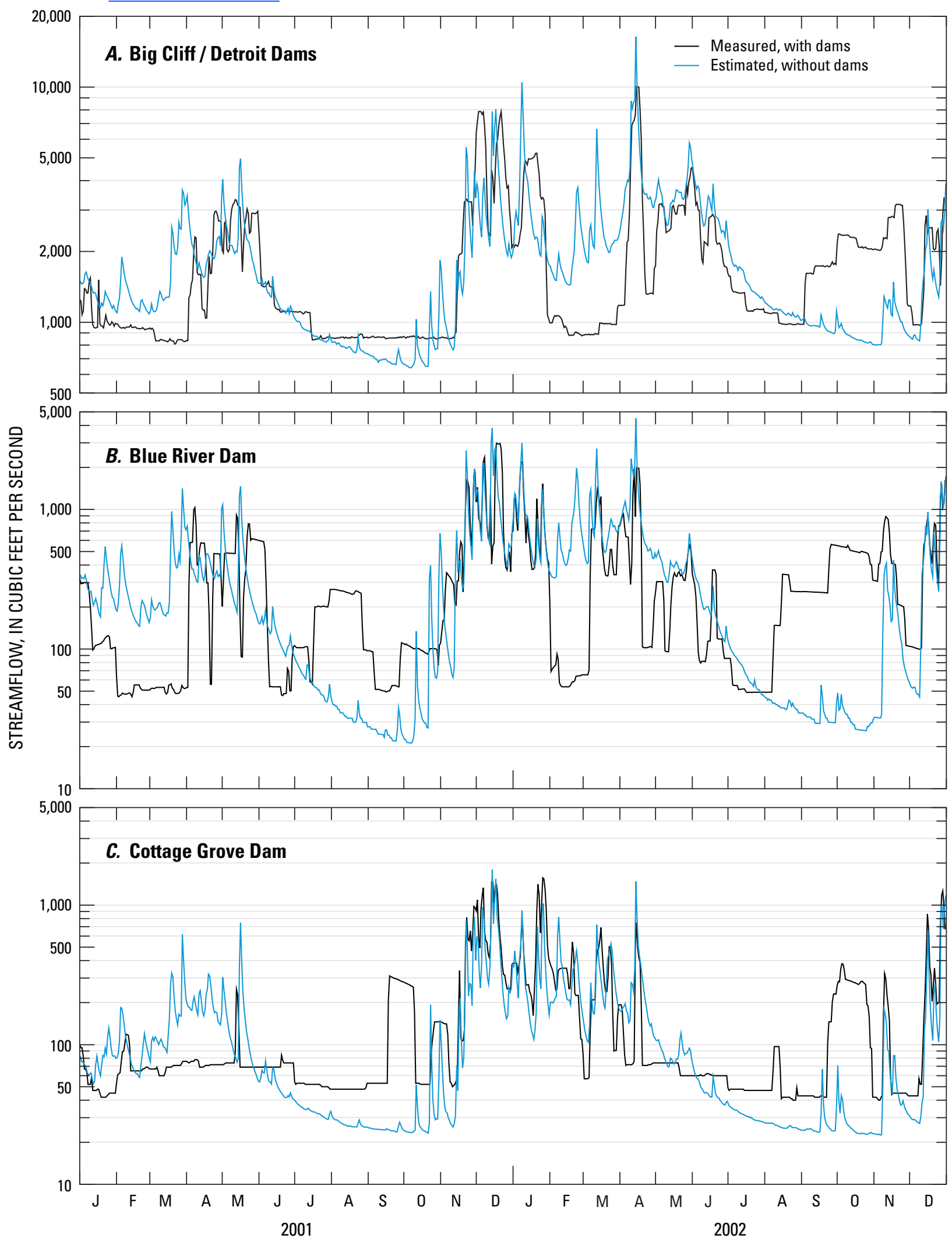

Figure A1. Measured and estimated streamflow for conditions with and without upstream dams at selected dam sites in the Willamette River basin, Oregon, 2001-02. Measured flow data are from USGS streamflow-gaging stations 14181500,14162200 , and 14153500 for graphs $A, B$, and $C$, respectively. 


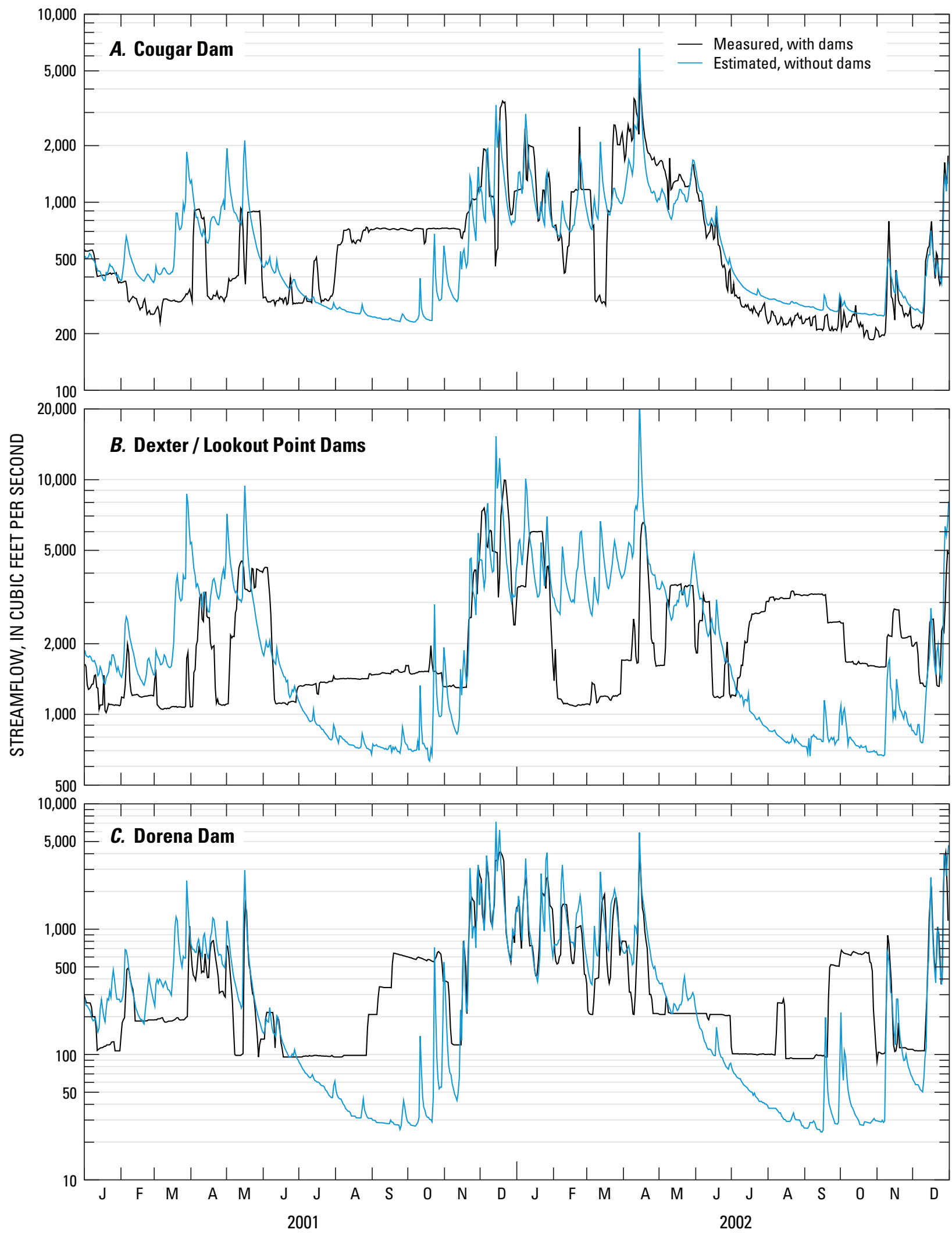

Figure A2. Measured and estimated streamflow for conditions with and without upstream dams at selected dam sites in the Willamette River basin, Oregon, 2001-02. Measured flow data are from USGS streamflow-gaging stations 14159500,14150000 , and 14155500 for graphs $A, B$, and $C$, respectively. 


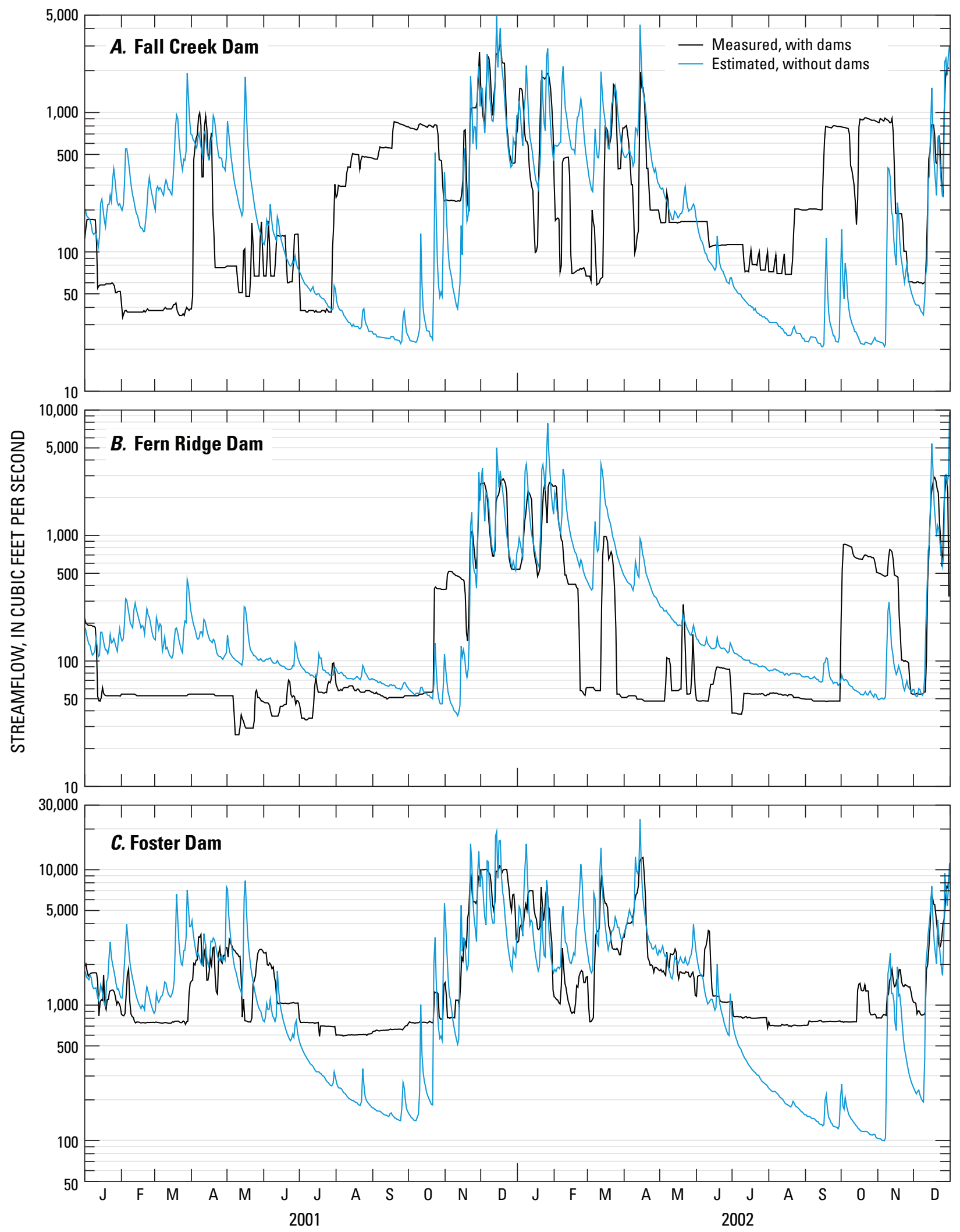

Figure A3. Measured and estimated streamflow for conditions with and without upstream dams at selected dam sites in the Willamette River basin, Oregon, 2001-02. Measured flow data are from USGS streamflowgaging stations 14151000,14169000 , and (14187200 minus 14187000) for graphs $A, B$, and $C$, respectively. 


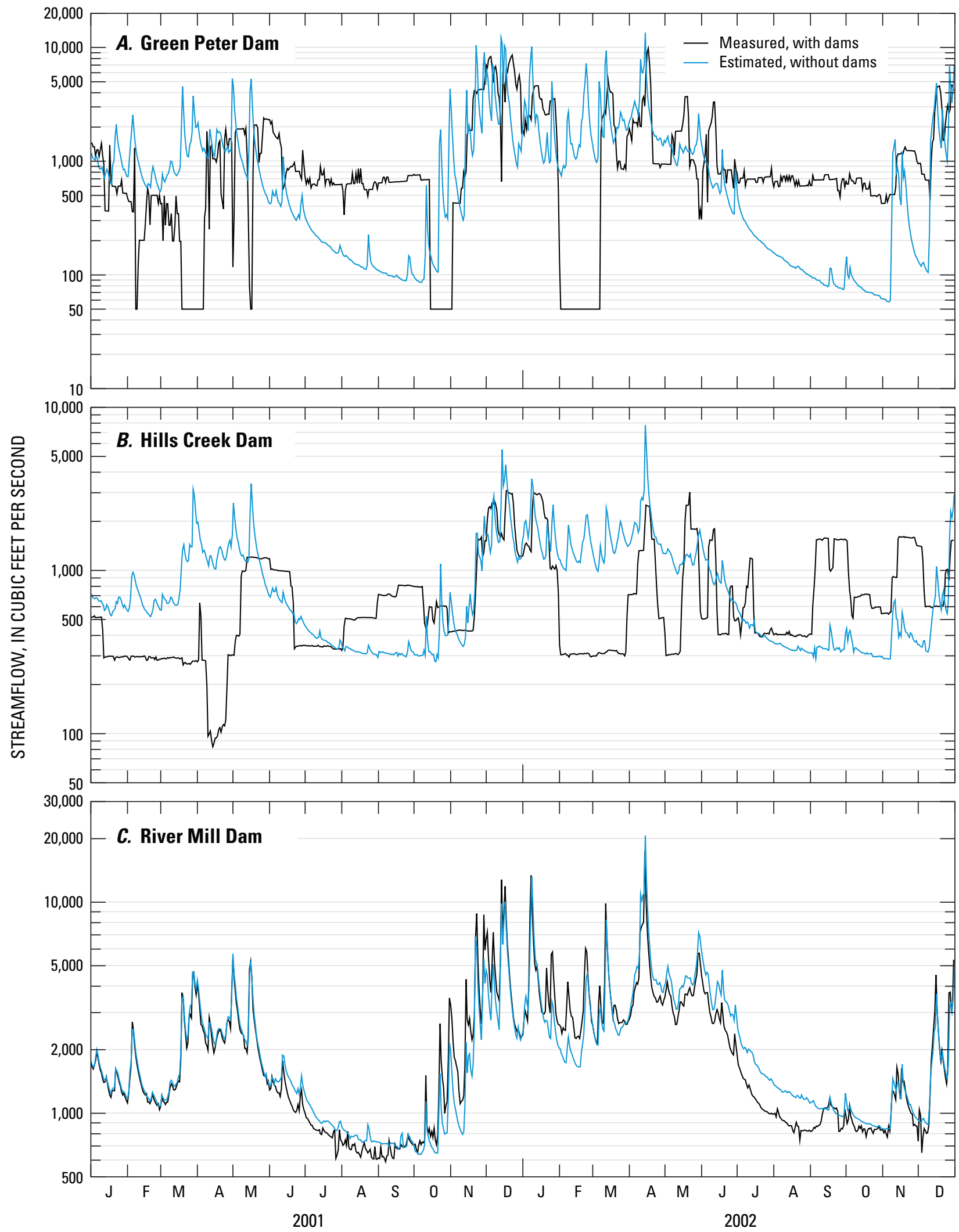

Figure A4. Measured and estimated streamflow for conditions with and without upstream dams at selected dam sites in the Willamette River basin, Oregon, 2001-02. Measured flow data in graphs $B$ and $C$ are from USGS streamflow-gaging stations 14145500 and 14210000 , respectively. Measured releases from Green Peter Dam were obtained from the U.S. Army Corps of Engineers. 


\section{Appendix B. Time/Distance Color Maps Showing the Downstream Thermal Effects of Willamette River Basin Dams}

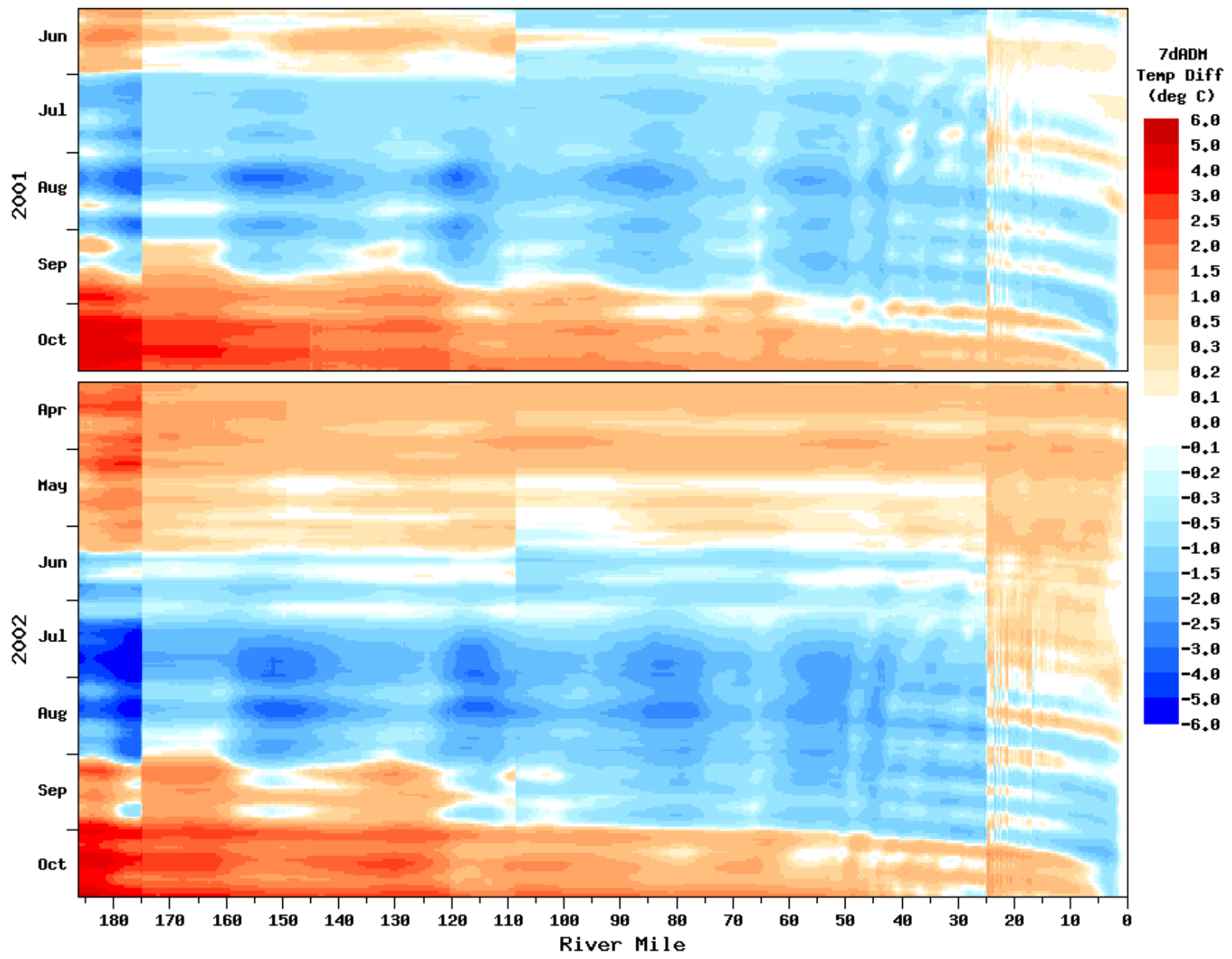

Figure B1. Time/distance color map showing modeled downstream thermal effects of dams on the entire Willamette River, Oregon, June-0ctober 2001 and April-0ctober 2002. Temperature changes in this figure are the difference in the modeled 7dADM temperatures for Natural Thermal Potential conditions with upstream dams minus the modeled 7dADM temperatures without upstream dams. The McKenzie, Long Tom, Santiam, and Clackamas Rivers join the Willamette River at river miles 174.9, 149.4, 108.5, and 24.9, respectively. 

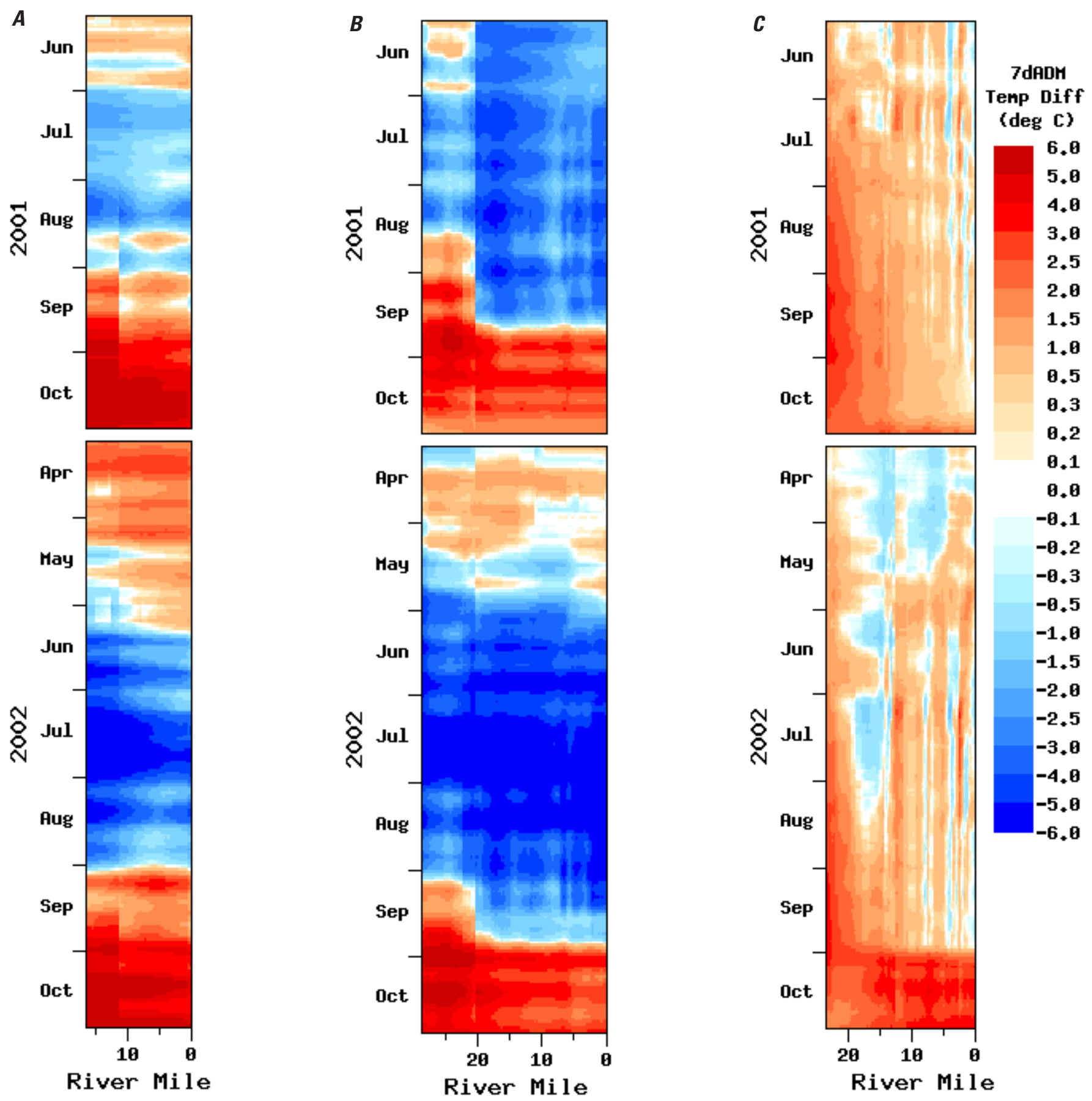

Figure B2. Time/distance color maps showing modeled downstream thermal effects of dams on $(A)$ the Middle Fork Willamette River, $(B)$ the Coast Fork Willamette River, and $(C)$ the Long Tom River, Oregon, June-October 2001 and April-October 2002. Temperature changes in this figure are the difference in the modeled 7dADM temperatures for Natural Thermal Potential conditions with upstream dams minus the modeled 7dADM temperatures without upstream dams. 

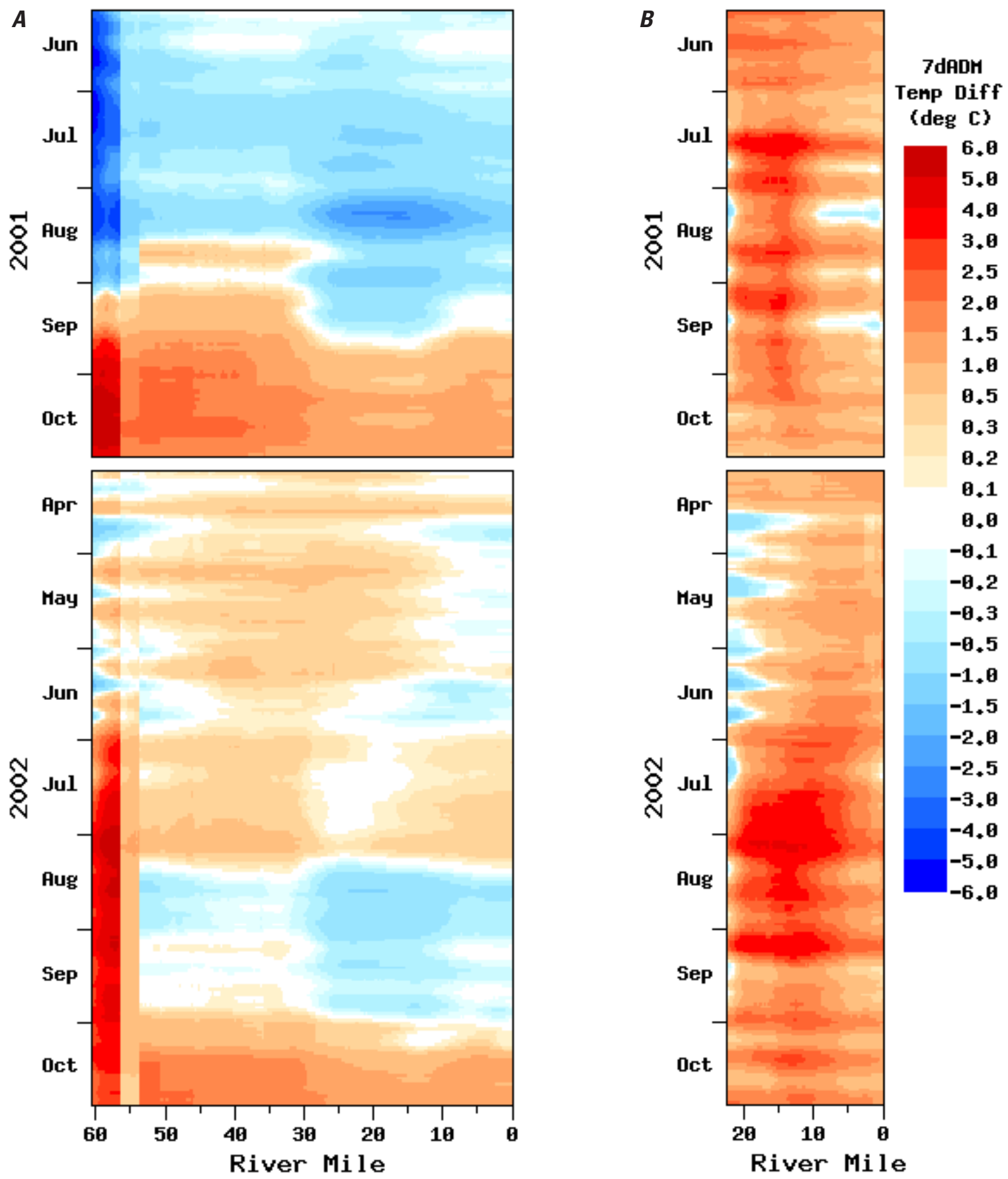

Figure B3. Time/distance color maps showing modeled downstream thermal effects of dams on $(A)$ the South Fork McKenzie and McKenzie Rivers, and $(B)$ the Clackamas River, Oregon, June-0ctober 2001 and April-0ctober 2002. Temperature changes are the difference in the modeled 7dADM temperatures for Natural Thermal Potential conditions with upstream dams minus the modeled 7dADM temperatures without upstream dams. Blue River joins the McKenzie River at river mile 54. 

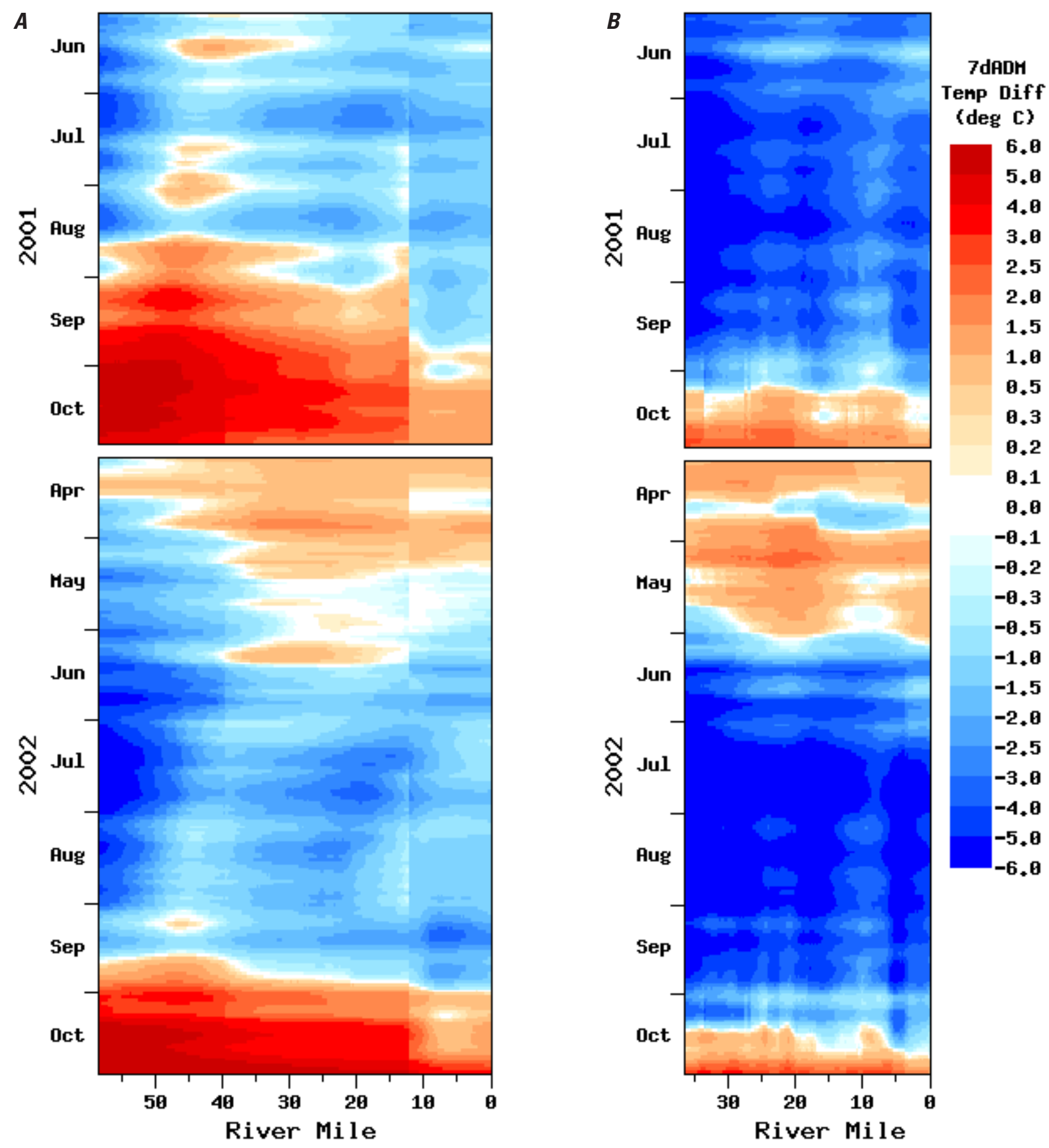

Figure B4. Time/distance color maps showing modeled downstream thermal effects of dams on $(A)$ the North Santiam and Santiam Rivers, and $(B)$ the South Santiam River, Oregon, June-0ctober 2001 and April-0ctober 2002. Temperature changes in this figure are the difference in the modeled 7dADM temperatures for Natural Thermal Potential conditions with upstream dams minus the modeled 7dADM temperatures without upstream dams. The North Santiam and South Santiam Rivers join at river mile 12.1. 
Appendix C. Graphs of Modeled Temperature Distributions Downstream of Willamette River Basin Dam Sites
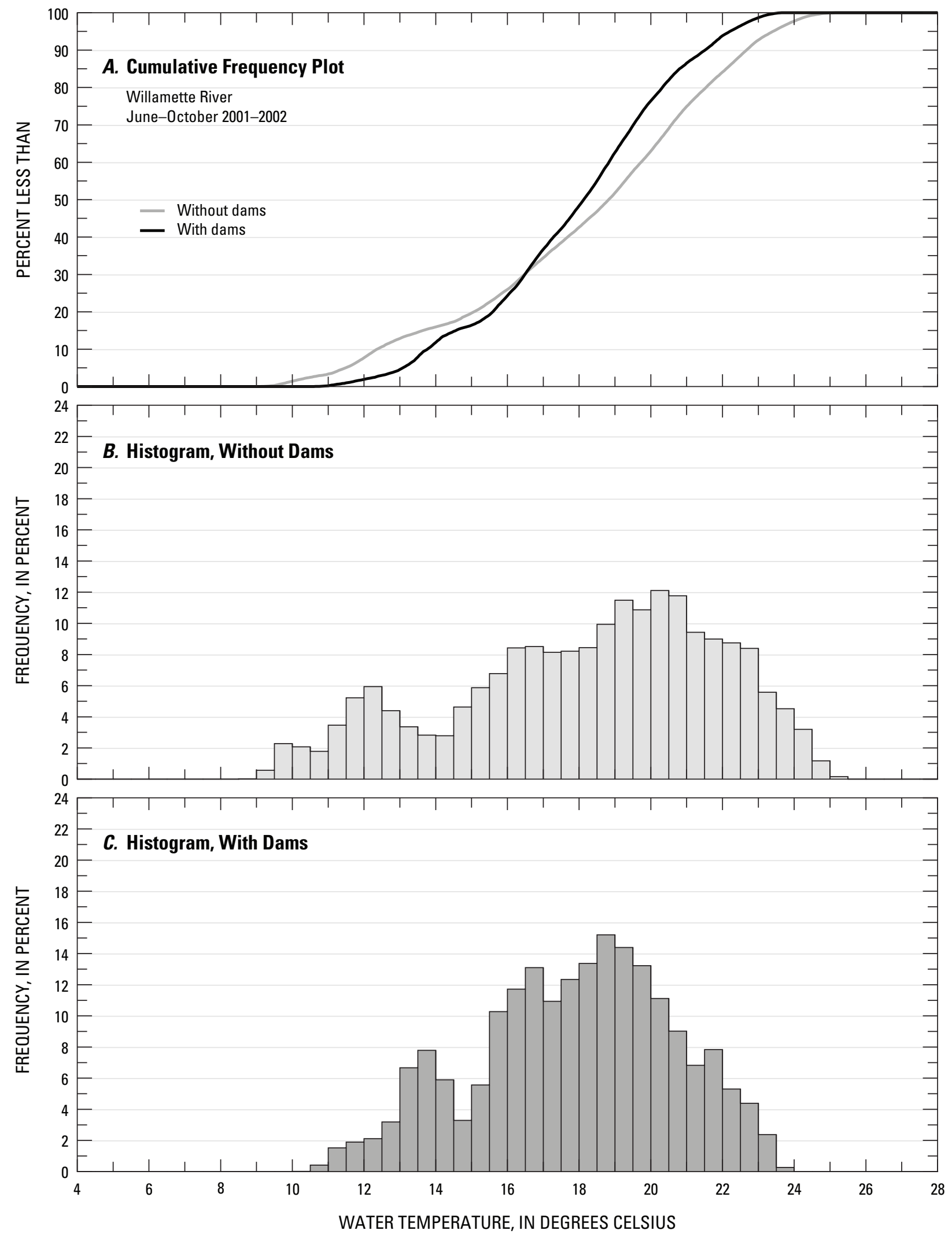

Figure C1. Cumulative frequency plot $(A)$ and histograms $(B, C)$ of modeled $7 \mathrm{~d} A D M$ temperatures for conditions with and without dams in the Willamette River downstream of the confluence of the Coast Fork and Middle Fork Willamette Rivers, Oregon, June-0ctober 2001-02. 

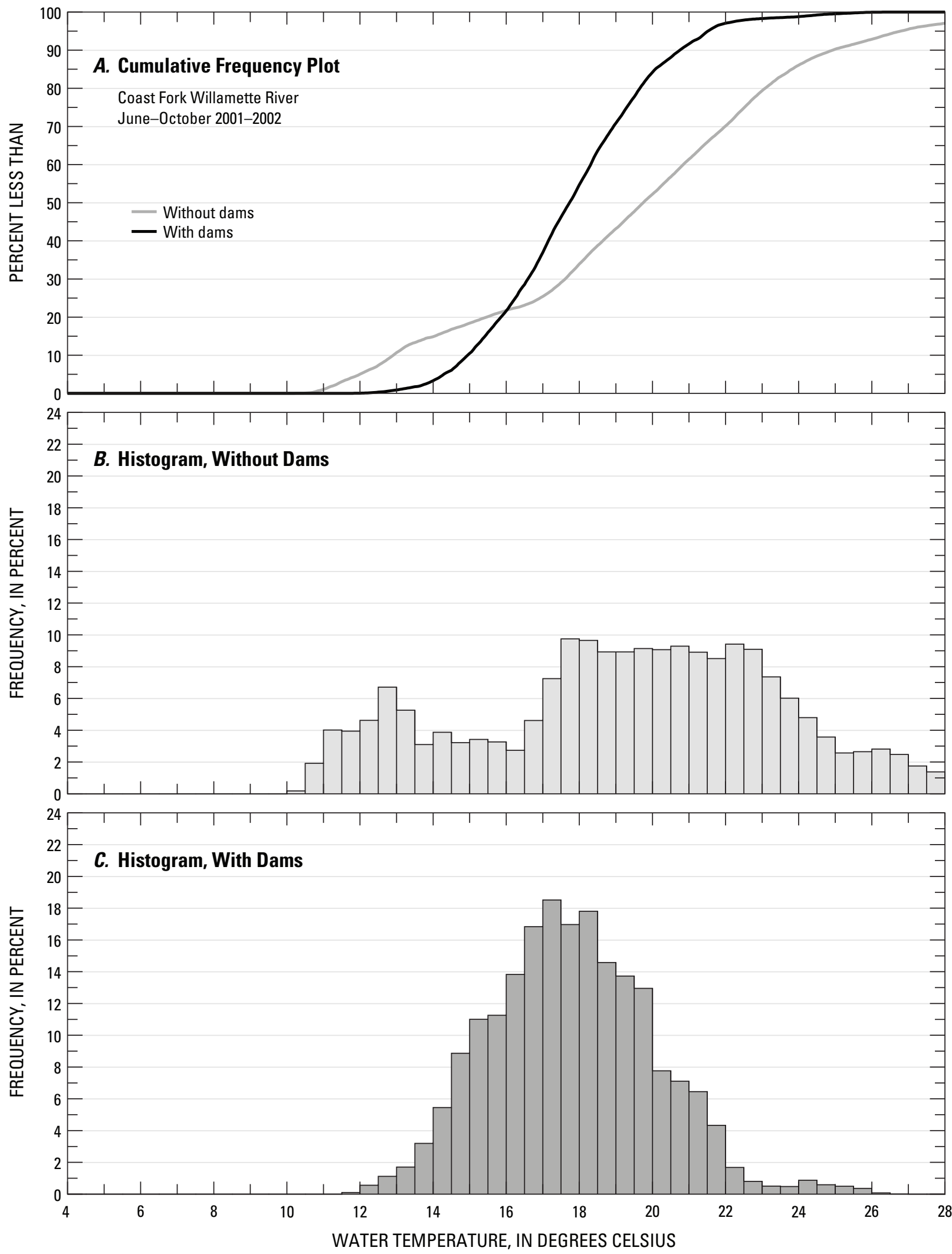

Figure C2. Cumulative frequency plot $(A)$ and histograms $(B, C)$ of modeled $7 \mathrm{~d} A D M$ temperatures for conditions with and without dams in the Coast Fork Willamette River downstream of Cottage Grove Dam, Oregon, JuneOctober 2001-02. The without-dams histogram is truncated at $28^{\circ} \mathrm{C}$; that part of the distribution (less than 5 percent of the total) is not shown because of problems modeling very low flows in the Coast Fork Willamette River. 

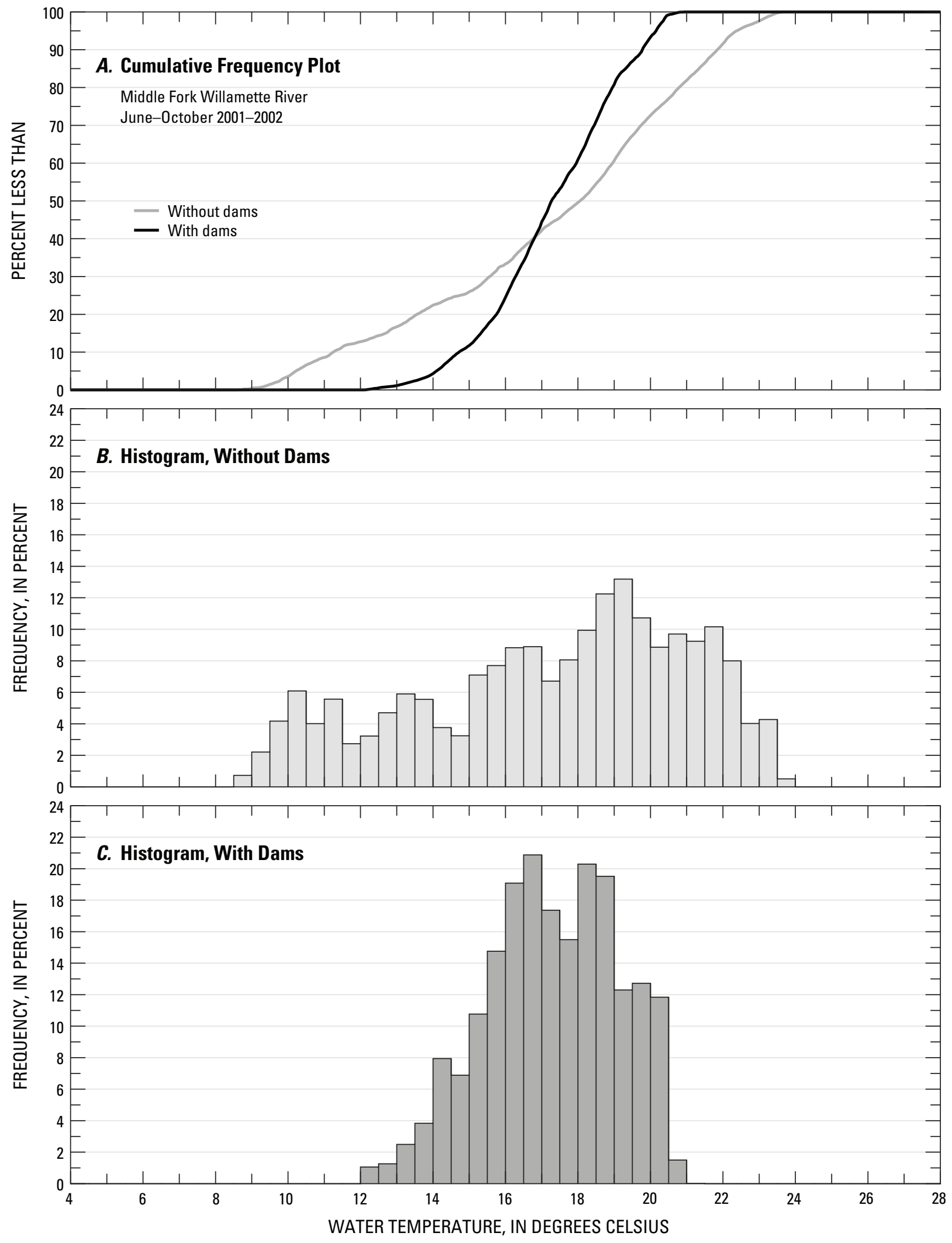

Figure C3. Cumulative frequency plot $(A)$ and histograms $(B, C)$ of modeled 7dADM temperatures for conditions with and without dams in the Middle Fork Willamette River downstream of Dexter Dam, Oregon, JuneOctober 2001-02. 

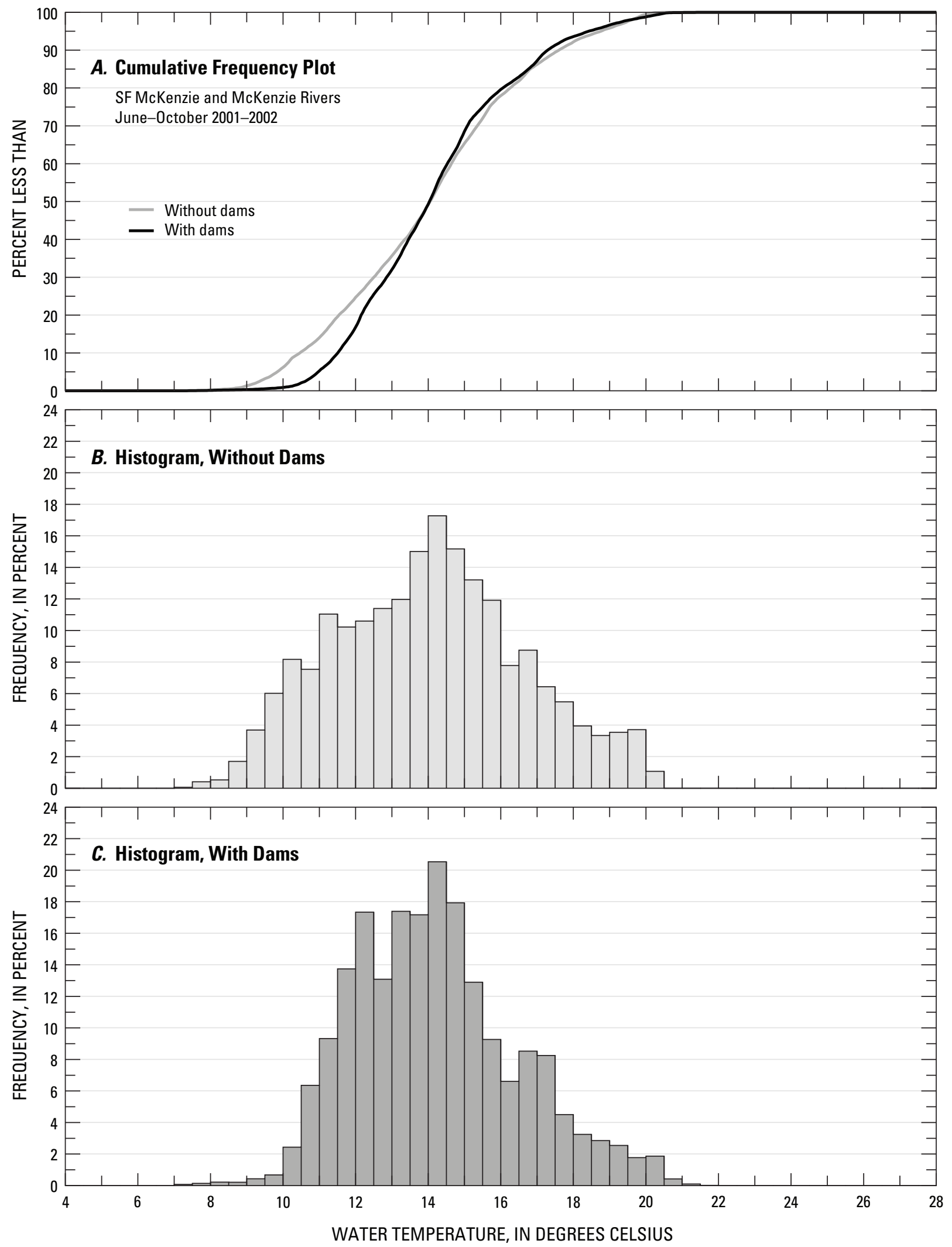

Figure C4. Cumulative frequency plot $(A)$ and histograms $(B, C)$ of modeled $7 \mathrm{~d} A D M$ temperatures for conditions with and without dams in the South Fork McKenzie and McKenzie Rivers downstream of Cougar Dam, Oregon, June-0ctober 2001-02. 

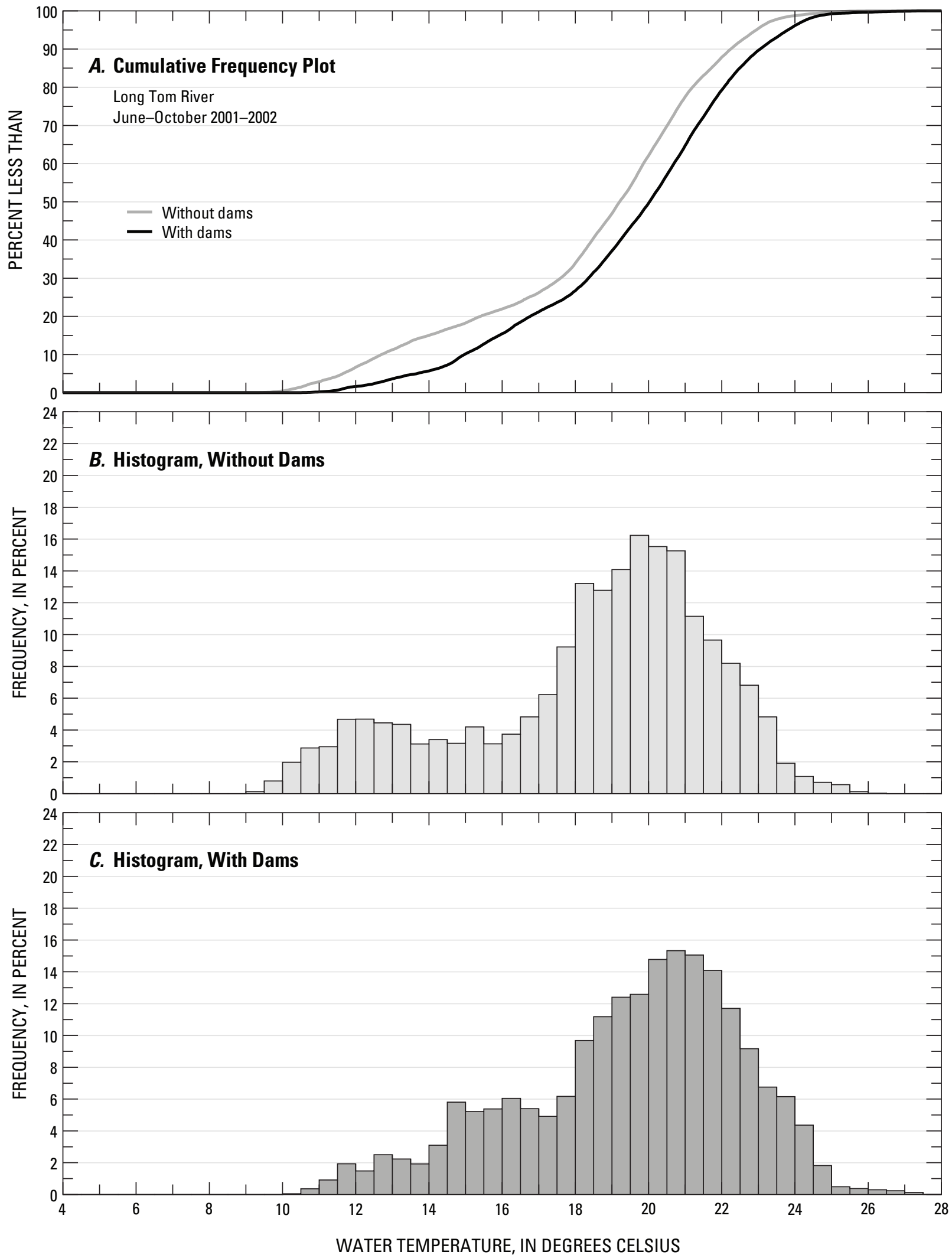

Figure C5. Cumulative frequency plot $(A)$ and histograms $(B, C)$ of modeled 7dADM temperatures for conditions with and without dams in the Long Tom River downstream of Fern Ridge Dam, Oregon, June-0ctober 2001-02. 

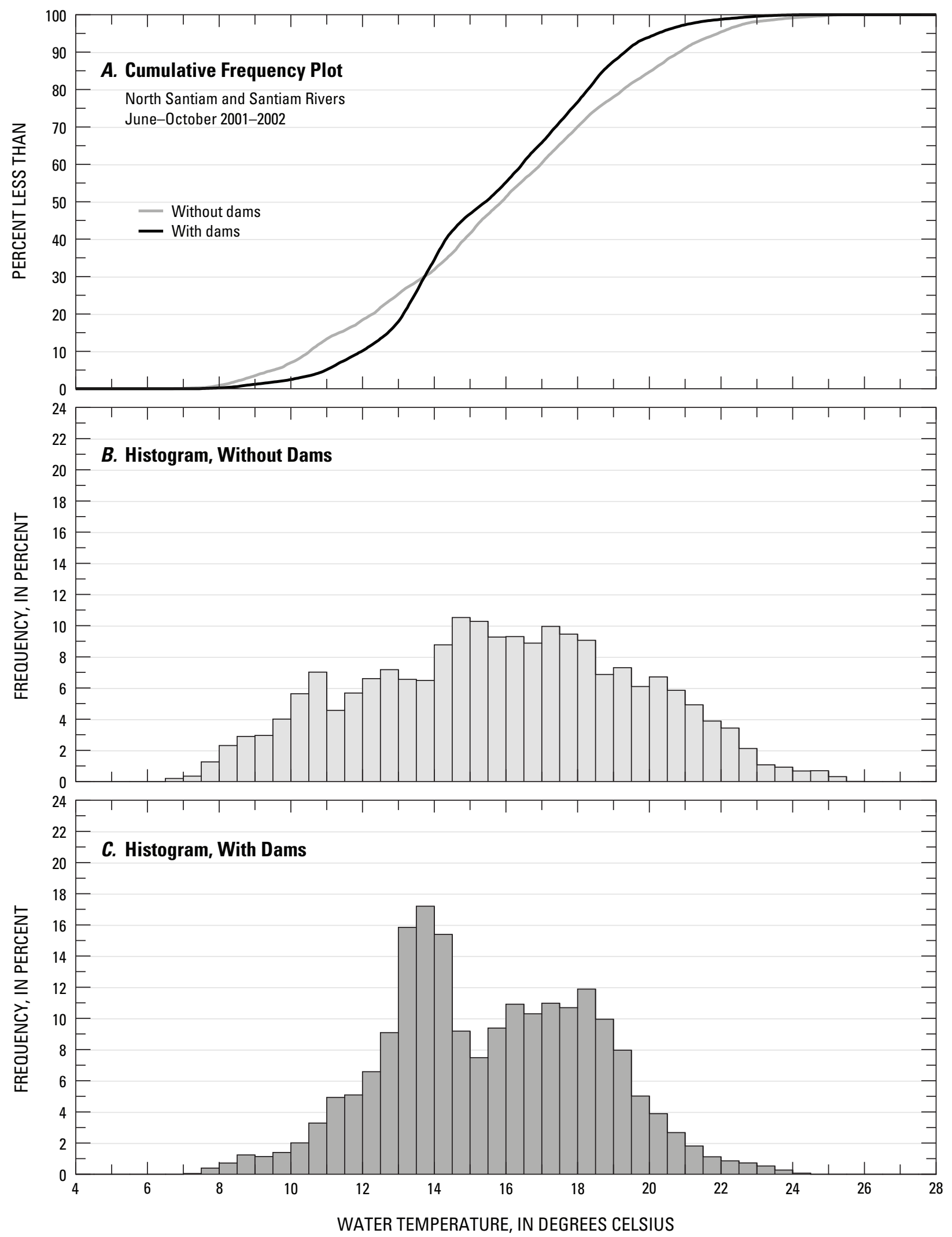

Figure C6. Cumulative frequency plot $(A)$ and histograms $(B, C)$ of modeled $7 \mathrm{~d} A D M$ temperatures for conditions with and without dams in the North Santiam and Santiam Rivers downstream of Big Cliff Dam, Oregon, JuneOctober 2001-02. 

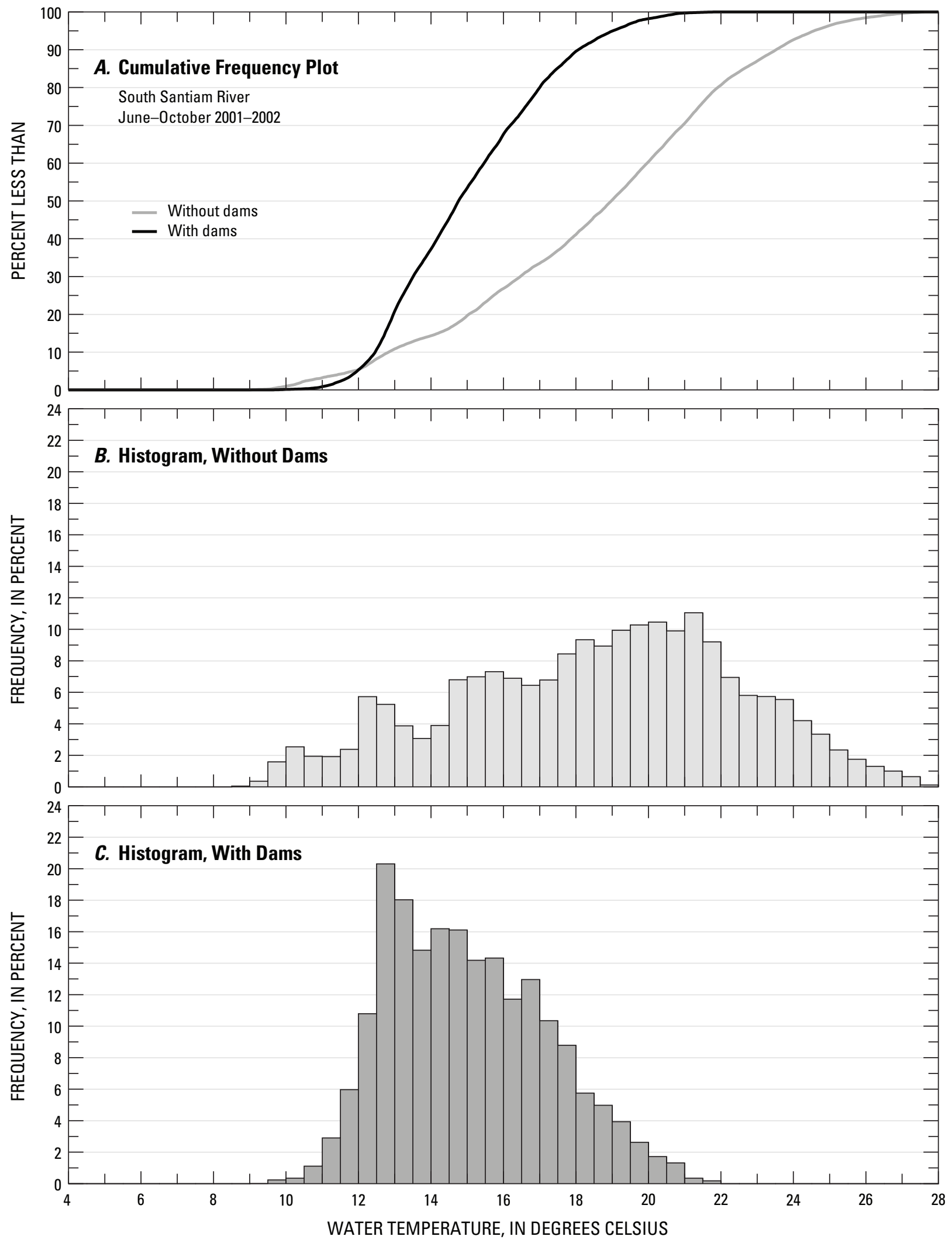

Figure C7. Cumulative frequency plot $(A)$ and histograms $(B, C)$ of modeled 7dADM temperatures for conditions with and without dams in the South Santiam River downstream of Foster Dam, Oregon, June-0ctober 2001-02. 

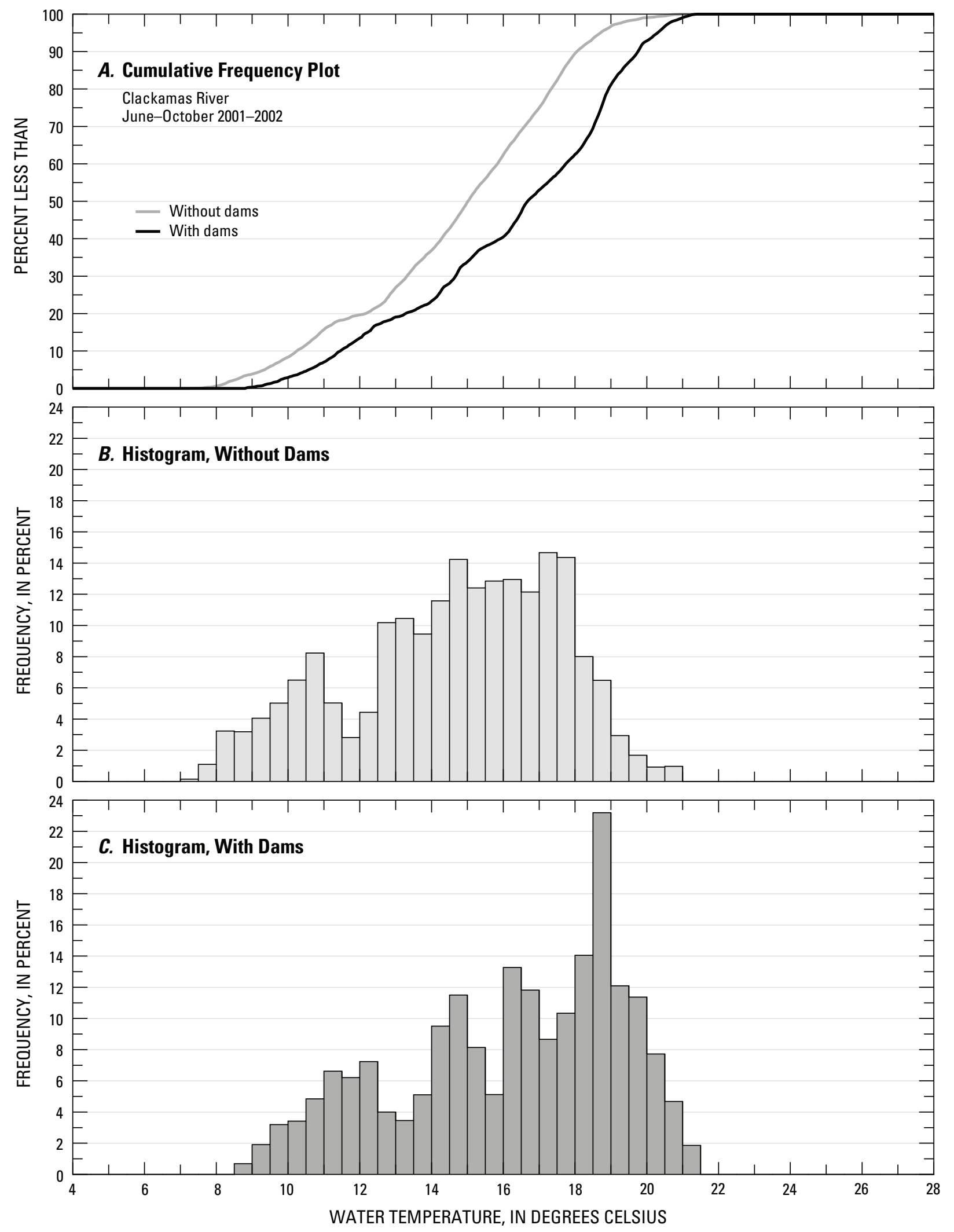

Figure C8. Cumulative frequency plot $(A)$ and histograms $(B, C)$ of modeled $7 \mathrm{dADM}$ temperatures for conditions with and without dams in the Clackamas River downstream of River Mill Dam, Oregon, June-October 2001-02. 
Thermal Effects of Dams in the Willamette River Basin, Oregon

This page intentionally left blank. 
Publishing support provided by the U.S. Geological Survey

Publishing Network, Tacoma Publishing Service Center

For more information concerning the research in this report, contact the Director, Oregon Water Science Center

U.S. Geological Survey

2130 SW 5th Avenue

Portland, Oregon 97201

http://or.water.usgs.gov 

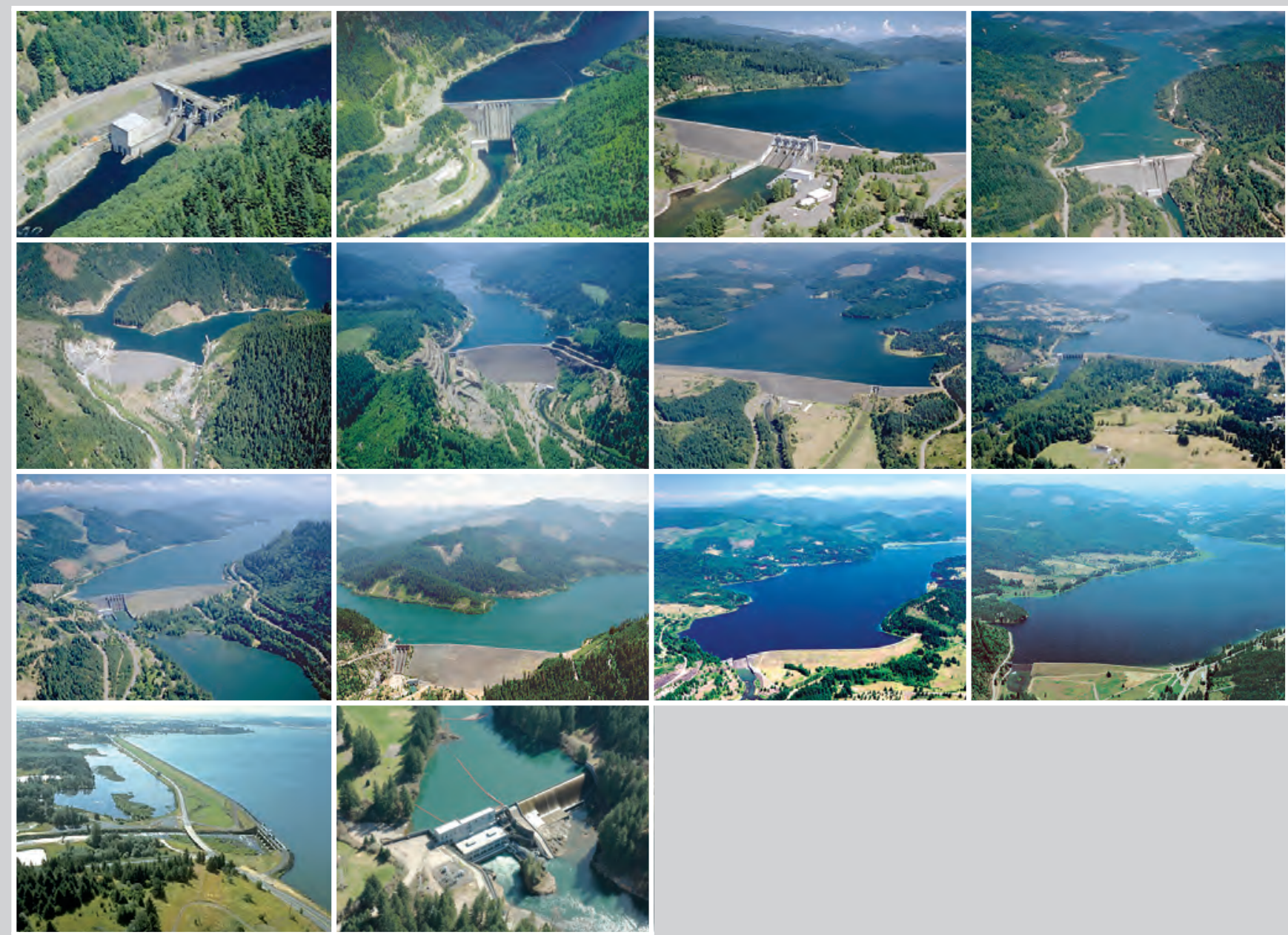

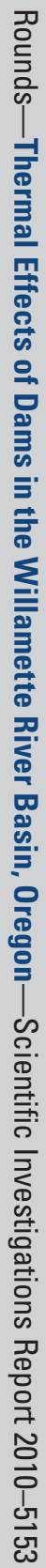

